\begin{tabular}{|c|c|c|c|c|c|c|c|c|c|c|c|}
\hline \multicolumn{4}{|c|}{$\begin{array}{l}\text { 2. To: (Receiving organization) } \\
\text { Distribution }\end{array}$} & \multicolumn{4}{|c|}{$\begin{array}{l}\text { 3. From: (originating Organization) } \\
\text { SNF Characterization Project/ } \\
\text { 2F700 }\end{array}$} & \multicolumn{4}{|c|}{$\begin{array}{r}\text { 4. Related EOT No.: } \\
\text { N/A }\end{array}$} \\
\hline \multicolumn{4}{|c|}{$\begin{array}{l}\text { 5. Proj./Prog./Dept./Div.: } \\
\text { Spent Nuclear Fuel Project }\end{array}$} & \multicolumn{4}{|c|}{$\begin{array}{l}\text { 6. Design Authority/ Design Agent/Cog. } \\
\text { Engr.: } \\
\text { R.B. Baker }\end{array}$} & \multicolumn{4}{|c|}{$\begin{array}{r}\text { 7. Purchase Order No.: } \\
\qquad \text { N/A }\end{array}$} \\
\hline \multirow{2}{*}{\multicolumn{8}{|c|}{$\begin{array}{l}\text { 8. Originator Remarks: } \\
\text { For approval and release. }\end{array}$}} & \multicolumn{4}{|c|}{$\begin{array}{r}\text { 9. Equip./Component No.: } \\
\text { N/A }\end{array}$} \\
\hline & & & & & & & & \multicolumn{4}{|c|}{$\begin{array}{c}\text { 10. System/Bldg./Facility: } \\
\text { N/A }\end{array}$} \\
\hline \multirow{4}{*}{\multicolumn{4}{|c|}{ 11. Receiver Remarks: }} & aseline & \multirow{4}{*}{\multicolumn{3}{|c|}{ [] Yes $[X]$ No }} & \multicolumn{4}{|c|}{ 12. Major Assm. Dwg. No.: } \\
\hline & & & & & & & & & $\mathrm{N} /$ & 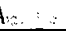 & \\
\hline & & & & & & & & \multicolumn{4}{|c|}{$\begin{array}{l}\text { 13. Permit/Permit Application No.: } \\
\text { N/A }\end{array}$} \\
\hline & & & & & & & & \multicolumn{4}{|c|}{$\begin{array}{l}\text { 14. Required Response Date: } \\
\text { N/A }\end{array}$} \\
\hline \multicolumn{8}{|c|}{ DATA TRANSM } & \multirow{2}{*}{\multicolumn{4}{|c|}{\begin{tabular}{|c|c|c|c|}
$(F)$ & $(G)$ & $(H)$ & $(I)$ \\
Approval & Reason & Origi- & Receiv- \\
Desig- & for & nator & er \\
nator & Trans- & Dispo- & Dispo- \\
& mittal & sition & sition \\
\end{tabular}}} \\
\hline \multicolumn{3}{|c|}{\begin{tabular}{l|l} 
(A) & \\
Item & (B) Document/Drawing No. \\
No. &
\end{tabular}} & $\begin{array}{l}\text { (C) } \\
\text { Sheet } \\
\text { No. }\end{array}$ & \begin{tabular}{l|l} 
(D) \\
Rev. \\
No.
\end{tabular} & (E) Title or Description o & ata Trar & smitted & & & & \\
\hline \multirow[t]{6}{*}{1} & \multicolumn{2}{|c|}{ HNF-3556 } & & 0 & $\begin{array}{l}\text { SAMPLING AND A } \\
\text { PLAN FOR. SLUDG } \\
\text { ON THE FLOOR A } \\
\text { PITS OF THE } 10 \\
\end{array}$ & $\begin{array}{l}\text { LYSI } \\
\text { LOCA } \\
\text { IN } \\
\text { K BA }\end{array}$ & $\begin{array}{l}\text { ED } \\
\text { HE } \\
\text { INS }\end{array}$ & $N / A$ & 2 & 1 & \\
\hline & \multicolumn{2}{|c|}{ 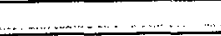 } & & & $\ldots$ & & & \multirow{2}{*}{\multicolumn{2}{|c|}{\begin{tabular}{c|c|}
$\cdots \cdots \cdots$ & $\ldots \ldots$ \\
\end{tabular}}} & & \\
\hline & \multicolumn{2}{|c|}{ 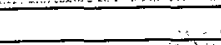 } & & & & & & & & & \\
\hline & \multicolumn{2}{|c|}{ 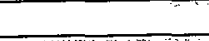 } & & & & & & \multicolumn{2}{|c|}{. } & $\because \because$ & \\
\hline & & & & & & & & & & & \\
\hline & & & & & & & & & & & \\
\hline 16. & & & & & $\overline{K E Y}$ & & & & & & \\
\hline $\mathrm{App}$ & val Desi & nator $(F)$ & Rea & on for Tra & nsmittal (G) & & & Dispos & $\ln (H) \&(I)$ & & \\
\hline $\begin{array}{l}\text { E, S, } \\
\text { isee W } \\
\text { Sec. } 1\end{array}$ & $\begin{array}{l}\mathrm{D} \text { or } \mathrm{N} / 1 \\
\mathrm{C}-\mathrm{CM}-3 \\
\text { 7) }\end{array}$ & $\begin{array}{l}\text { 1. Ap } \\
\text { 2. Rel } \\
\text { 3. Inf }\end{array}$ & $\begin{array}{ll}\text { proval } & 4 . \\
\text { oase } & 5 . \\
\text { ormation } & 6 .\end{array}$ & $\begin{array}{l}\text { Riew } \\
\text { Ost-Revie } \\
\text { ist. (Rece }\end{array}$ & eipt Acknow. Required) & & roved & $\begin{array}{l}\text { nment } \\
\text { comment }\end{array}$ & $\begin{array}{l}\text { 4. Reviewe } \\
\text { 5. Reviewe } \\
\text { 6. Receipt }\end{array}$ & $\begin{array}{l}\text { no/comm } \\
\text { w/comm } \\
\text { knowled }\end{array}$ & \\
\hline & & & & See & $\begin{array}{l}\text { 17. SIGNATURE/DISTRIE } \\
\text { pproval Designator for requ }\end{array}$ & I signat & & & & & \\
\hline $\begin{array}{l}\text { (G) } \\
\text { Rea- } \\
\text { son }\end{array}$ & $\begin{array}{c}\text { (H) } \\
\text { Disp. }\end{array}$ & (J) Name & (K) Signature & (L) Date & (M) MSIN & $\begin{array}{l}\text { (H) } \\
\text { Disp. }\end{array}$ & (J) $\mathrm{Na}$ & (K) & grature & Date & M) MSIN \\
\hline & & Design Authorit & & & $i$ & 1 & C.A.P & ersen (NH & capte & 11 & $47 / 47-20$ \\
\hline & & Design Agent & & & 1 & $l$ & M.J. H & ota (QA) & $m, 2$ & $n<-4$ & $B 1-13$ \\
\hline 1 & 1 & Cog.Eng. R.B. & Baker/QB & $\log \pi$ & $7 / 12 / 8+10-40$ & 1 & T.L.W & $\sin 10$ & 106 & $416-16-9$ & $74-40$ \\
\hline 1 & 1 & Cog. Mgr: D.W. & Bergmani $\alpha$ & 12 & $A / 2 / 4040$ & 1 & P.J.M & Farian & IIIA & $4=$ & $40-40$ \\
\hline 1 & i & QA D.W. Smith & QSeng & Whin & my & 1 & H.W. R & gerford & textabs & Xe 1111 & $8 \quad \quad 17-20$ \\
\hline 1 & 1 & B.J. Makenas & $312 \%$ & Lem & $4 / 3+30-40^{\circ}$ & 1 & D.A. D & d $2222-s$ & $c=$ & al & $7796-50$ \\
\hline 1 & 9 & K.L. Pearce $\nvdash$ & Dores & $11 / 18$ & $9 / 98 \quad 177-20$ & 1 & K.L. S & vers $(32$ & 6 & 2 & K9-08 \\
\hline $\begin{array}{l}18 . \\
\text { R.B. } \\
\text { Signa } \\
\text { Origin }\end{array}$ & $\frac{3}{3}$ of & E. $11 / 12 / 98$ & $\begin{array}{l}\text { Authotized Rer } \\
\text { for Receiving }\end{array}$ & ganizatior & $\begin{array}{l}\text { Desigf Afut } \\
\text { Cognnizant }\end{array}$ & & & $\begin{array}{ll}\text { 21. } & \text { DOE } \\
\text { Ctr } \\
\text { Ctr } \\
\text { App } \\
{\left[\begin{array}{ll}\text { App } \\
\text { J }\end{array}\right.} & \text { Dis }\end{array}$ & $\begin{array}{l}\text { PPROYAL } \\
\text { No. } \\
\text { oved } \\
\text { oved W/co } \\
\text { oproved w }\end{array}$ & $\begin{array}{l}\text { if requ } \\
\text { ments } \\
\text { comment }\end{array}$ & (red) $1 / 7 / 5$ \\
\hline
\end{tabular}

BD-7400-172-2(05/96) GEF097 


\title{
SAMPLING AND ANALYSIS PLAN FOR SLUDGE LOCATED ON THE FLOOR AND IN THE PITS OF THE 105-K BASINS
}

\author{
R. B. Baker \\ Duke Engineering \& Services Hanford, Inc., Richland, WA 99352 \\ U.S. Department of Energy Contract DE-AC06-96RL13200
EDT/ECN: $620822 \quad$ UC: UC 2070
Org Code: 2F700 Charge Code: 105358 \\ B\&R Code: EW7040000 Tota7 Pages: 95
}

Key Words: K Basin, Sludge, Sampling and Analyses

Abstract: This Sampling and Analysis Plan (SAP) provides direction for the sampling of the sludge found on the floor and in the remote pits of the 105-K Basins to provide: (1) basic data for the sludges that have not been characterized to-date and (2) representative sludge material for process tests to be made by the SNF Project/K Basins sludge treatment process subproject. The sampling equipment developed will remove representative samples of the radjoactive sludge from underwater at the $K$ Basins, depositing them in shielded containers for transport to the Hanford Site laboratories. Included in the present document is the basic background logic for selection of the samples to meet the requirements established in the Data Quality Objectives (DQO), HNF-2033, for this sampling activity. The present document also includes the laboratory analyses, methods, procedures, and reporting that will be required to meet the DQO

TRADEMARK DISCLAIMER. Reference herein to any specific commercial product, process, or service by trade name, trademark, manufacturer, or otherwise, does not necessarily constitute or imply its endorsement, recommendation, or favoring by the United states Government or any agency thereof or its contractors or subcontractors.

Printed in the United States of America. To obtain copies of this document, contact: Document Control Services, P.O. Box 950, Mailstop H6-08, Richland WA 99352, Phone (509) 372-2420; Fax (509) 376.4989.
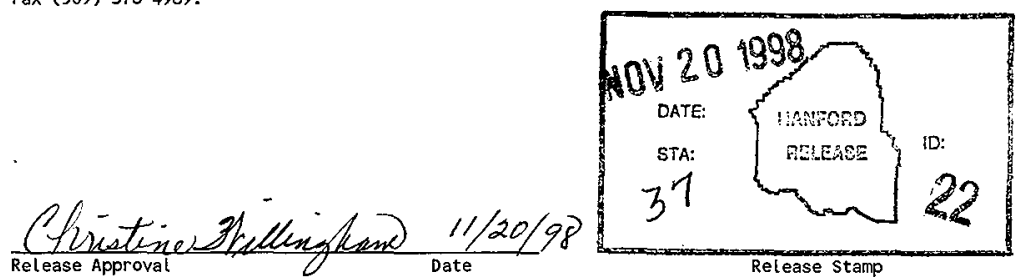
HNF-3556, Rev. 0

SAMPLING AND ANALYSIS PLAN FOR SLUDGE LOCATED ON THE FLOOR AND IN THE PITS OF THE 105-K BASINS

R. B. Baker, T. L. Welsh, B. J. Makenas, and K. L. Pearce

November 1998 
HNF-3556; Rev. 0

\section{CONTENTS}

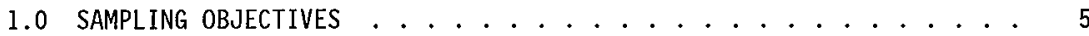

1.1 PURPOSE . . . . . . . . . . . . . 6

1.2 SAMPLING AND ANALYSIS ACTIVITY OBJECTIVE AND GOALS . . . . 8

2.0 105-K WEST AND 105-K EAST BASINS STATUS AND SAMPLING

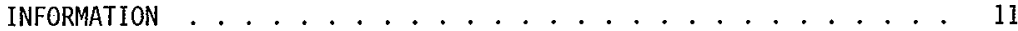

2.1 105-K WEST BASIN SLUDGE CHARACTERIZATION STATUS . . . . . . 11

$2.2105-K$ EAST BASIN SLUDGE CHARACTERIZATION STATUS . . . . . . 12

2.3 SAMPLING INFORMATION ................ 15

2.3.1 Sample Collection and Handling .......... 15

2.3.3 Field Sample Plan Modifications .......... . 19

2.3.4 Basis and Locations of Sampling ......... . 19

2.3.5 Sample Recovery, Final Compositing, and Preparation 30

3.0 LABORATORY ANALYSIS INSTRUCTIONS . . . . . . . . . . 35

3.1 GENERAL . . . . . . . . . . . . . . . . . 35

3.2 ANALYSES ..................... 36

4.0 LABORATORY REPORTING REQUIREMENTS . . . . . . . . . . . . . . 47

4.1 DATA PACKAGING ..................... 47

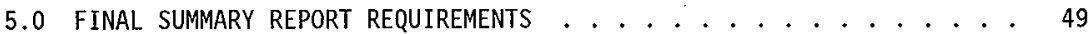

5.1 STATISTICAL ANALYSIS REQUIREMENTS . . . . . . . . . . . 49

6.0 SAFETY PLANS . . . . . . . . . . . . . . . . . 51

6.1 RADIATION/INDUSTRIAL SAFETY . . . . . . . . . . . . 51

6.2 NUCLEAR CRITICALITY SAFETY . . . . . . . . . 51

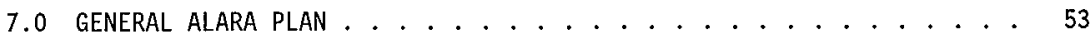

8.0 QUALITY ASSURANCE AND CONTROL PLAN ............. 55

9.0 REFERENCES . . . . . . . . . . . . . . . . 57

APPENDIX A SUMMARY LETTER (DESH-9857199) DOCUMENTING

ESTIMATED VOLUMES OF SLUDGE IN K BASINS . . . . . . 61

APPENDIX B SLUDGE DEPTH ESTIMATES AND SAMPLE LOCATIONS

DETAIL FOR K WEST AND K EAST BASINS . . . . . . . 77 


\section{LIST OF FIGURES}

1. Sludge Escaping Out Screened Holes in the Bottom of K East Basin Canister During Typical Move . . . . . . . . . 13

2. Overview of the Sludge Core or Primary Floor Sampling Equipment

3. Overview of the Consolidated Floor STudge Sampling Equipment . . . 17

4. K West Basin Floor and Pit Sample Locations . . . . . . . . . 26

5. K East Basin Floor and Pit Samples... . . . . . . . . . . 29

6. Flow Chart of Sludge Sample Processing and Analyses . . . . . . 44

\section{LIST OF TABLES}

1. General Sampling Scope Proposed by Data Quality Objectives for Current Sampling. . . . . . . . . . . . 12

2. Floor and Pit Sludge Sampling Locations ......... 20

3. Summary of $K$ Basins Floor and Pit STudge Sampling

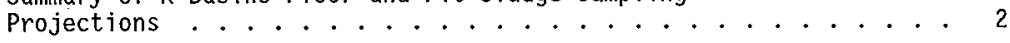

4. Overall Comparison of Proposed Targets from Data Quality Objectives to Present Sampling Projections for $K$ East and $K$ West Floor and Pit Sludge .............. 22

5. Summary of Sample Primary Uses, Sampler Used, and Compositing .................. 24

6. Summary of Composited Samples . . . . . . . . . . . . 25

7. Proposed Responsible Laboratory and Sample Condition for the Floor and Pit Sludge Samples........... 33

8. 105-K West and K East Basins Floor and Pit Sludge Analyses . . . 37

9. Analytical Requirements for the $105-K$ West and East Basins

Floor and Pit Sludge Samples.............. 
HNF-3556, Rev. 0

\section{LIST OF TERMS}

$\begin{array}{ll}\text { ALARA } & \text { As Low As Reasonably Achievable } \\ \text { ANOVA } & \text { Analysis of Variance } \\ \text { AEA } & \text { Alpha Energy Analysis } \\ \text { Basin } & \text { 105-K West or East (as used in context) Irradiated } \\ & \text { FueT Storage Basin } \\ \text { CERCLA } & \text { Comprehensive Environmental Response, Compensation, } \\ & \text { and Liability Act } \\ \text { CSB } & \text { Canister Storage Building } \\ \text { DESH } & \text { Duke Engineering \& Services Hanford, Inc. } \\ \text { DQO } & \text { Data Quality Objective } \\ \text { DSC } & \text { Differential Scanning Calorimetry } \\ \text { DST } & \text { Double Shel1 Tank } \\ \text { ECD } & \text { Electron Capture Detection } \\ \text { EPA } & \text { EnvironmentaI Protection Agency } \\ \text { ERDF } & \text { Environmental Remediation Disposal Facility } \\ \text { GC } & \text { Gas Chromatography } \\ \text { GEA } & \text { Gamma Energy Analysis } \\ \text { IC } & \text { Ion Chromatography } \\ \text { ICP } & \text { Inductively Coupled PTasma } \\ \text { ISE } & \text { Ion Specific Electrode } \\ \text { IXM } & \text { Ion Exchange Module (at K West Basin) } \\ \text { Main Basin } & \text { 105-K Irradiated Fuel Storage Basins Exclusive of Remote Pits } \\ \text { MCO } & \text { Multi-Canister Overpack } \\ \text { MDL } & \text { Minimum Detection Limit } \\ \text { NDT } & \text { Nondestructive Testing } \\ \text { NHC } & \text { Numatec Hanford Company } \\ \text { PCB } & \text { Polychlorinated Biphenyls } \\ \text { PHMC } & \text { Project Hanford Management Contract } \\ \text { PNNL } & \text { Pacific Northwest National Laboratories } \\ \text { ppb } & \text { parts per billion } \\ \text { ppm } & \text { parts per million } \\ \text { PQL } & \text { Practical Quantitation Limit } \\ \text { PTFE } & \text { polytetrafluoroethylene } \\ \text { QA } & \text { Quality Assurance } \\ \text { QC } & \text { Quality Control } \\ \text { RCRA } & \text { Resource Conservation Recovery Act of 1976 } \\ \text { RPD } & \text { Relative Percent Difference; [|(result1 - result2) |/mean]*100 } \\ \text { SAP } & \text { Sampling and Analysis Plan } \\ \text { SAR } & \text { Safety and Analysis Report } \\ \text { SARP } & \text { Safety and Analysis Report for Packaging } \\ \text { SD } & \text { Serial Dilution } \\ \text { SFBWP } & \text { Sand Filter Backwash Pit } \\ \text { SNFCP } & \text { Spent Nuclear Fuel Characterization Project } \\ \text { SOW } & \text { Statement of Work } \\ \text { SP } & \text { Spike Analysis } \\ \text { SPC } & \text { Statistical Process Control } \\ \text { SVOA } & \text { Semivolatile Organic Analysis } \\ \text { TC } & \text { Total Carbon } \\ \text { TCLP } & \text { Toxicity Characterization Leaching Procedure } \\ & \end{array}$


HNF-3556, Rev. 0

\section{LIST OF TERMS (Continued)}

TGA

TIC

TICs

TIMS

TLD

TOC

TSCA

TWRS

VOA

WHC

$\mathrm{XRD}$
Thermal Gravimetric Analysis

Total Inorganic Carbon

Tentatively Identified Compounds

Thermal Ionization Mass Spectroscopy

Thermoluminescent Dosimeter

Total Organic Carbon

Toxic Substances Control Act

Tank Waste Remediation System

Volatile Organic Analysis

Westinghouse Hanford Company

$X$-Ray Diffraction 
HNF-3556, Rev. 0

\section{SAMPLING AND ANALYSIS PLAN FOR SLUDGE LOCATED ON THE FLOOR AND IN THE PITS OF THE 105-K BASINS}

\subsection{SAMPLING OBJECTIVES}

\section{Notice}

As the present document is being completed the Spent Nuclear Fuel (SNF) project management and SNF Sludge Treatment Process subproject have just finished a review of the cost and benefits related to characterization and process testing data supporting treatment of $\mathrm{K}$ Basin sludges. The conclusions of this review are: (1) the benefits (i.e., reduced risks, design basis data, sludge material for process testing, etc.) do not warrant any further sampling or characterization of sludges in the K West Basin and (2) the additional sampling at $\mathrm{K}$ East Basin is warranted and should be completed. The project basis for this is the assumption the $\mathrm{K}$ East Basin sludge behavior conservatively bounds that of the sludges at the $\mathrm{K}$ West Basin. Based on these conclusions no further sampling of sludges will be attempted from the floors or spent fuel storage canisters at $\mathrm{K}$ West Basin to support process treatment development and confirmation.

By this notice the reader is being informed that the $K$ West samples will not be taken. In order to maintain required project schedules for the current sludge sampling activities that are imminent, while maintaining consistent basis documentation:

- The present Sampling and Analyses Plan (SAP) retains the references to the original sampling planned for the $\mathrm{K}$ West floor sludge.

- The K East Basin floor sludge samples described in the present SAP will be taken now as planned (this will maintain project schedules while being consistent with documentation).

- During the period of time required to take the $K$ East Basin samples, the sampling basis documentation (e.g., data quality objectives, etc.) will be revised reflecting the change of emphasis in sampling (i.e., sampling sludges only at K East Basin).

- Using the revised basis documents the present SAP will be revised as necessary to assure the needs of the Sludge Treatment Process subproject are met for sample material needed for process validation testing.

This latter item may require additional sludge sample material from the $\mathrm{K}$ East Basin floor to provide sufficient sludge for validation tests. The equipment for sampling floor sludge at the $\mathrm{K}$ Basins will be maintained until the revisions of the basis documents are complete. 
HNF-3556, Rev. 0

\subsection{PURPOSE}

The data quality objectives (DQOs) for this sludge sampling campaign are provided in Makenas (1998a). The purpose of this sampling and analysis plan (SAP) is to define the strategy and the methods that will be used to sample and analyze the sludge (1) located on the floor of the main basin and pits at 105-K West and (2) in selected locations in similar areas at the 105-K East Basin. The objectives for the sampling were rigorously developed by the Spent Nuclear Fuel (SNF) sludge treatment process subproject over the past year and are documented in the general subproject DQO (Pearce 1998a), and the testing strategy documents (Delegard 1998; Flament 1998a), followed by the specific sampling DQO (Makenas 1998) for this SAP. These objectives were further confirmed by the independent review team for the initial sludge process flow diagram (PFD) for treatment (Flament 1998b; Fink 1998). This team strongly encouraged continued characterization of the sludge feed materials to clarify the nominal and bounding cases involved.

The $K$ West and $K$ East Basins floor and pit sludge is generally expected to be a nonhomogeneous mixture of particulate materials containing some fuel element corrosion products, environmental materials such as sand and insects, rack and canister corrosion products, sloughed-off concrete material, paint flakes from racks, and/or fuel element fission products. The $K$ West Basin sludge is expected to be somewhat simjlar in composition to that found to date in K East (Section 2.2 and Makenas 1996c) but with less fuel element related materials, because the canister barrels have 1 ids and barrels have no slots or holes. K West sludges may also contain loose canister lid seal material (e.g., Grafoil), materials related to sludge like material from other Hanford facilities (e.g., many canisters in $K$ West Basin were sealed in $N$ Basin), jon-exchange-module (IXM)-re]ated materials (differing from K East Basin) that were spilled during basin operations, sand and unique basin material backflushed from the basin sand filter, and basin wall materials including sealer.

Sludge from a number of locations on the $K$ East Basin floor and in the Wease1 Pit was sampled in 1995, characterized and documented (Makenas 1996c). $A$ number of the samples in the present campaign are being taken in related locations to provide both supplementary analyses and material required for sludge chemical process treatment testing (Flament 1998a). The original floor sludge sample material taken in 1995 was not envisioned to be used to support a treatment development project. Therefore, the quantity of sample taken at that time was purposely kept close to the quantity needed only for projected characterization analyses at that time (to minimize waste and returns to $K$ Basins). Thus, even with only initial testing for the sludge treatment process completed the available sludge sample material from the 1995 sampling campaign has been depleted in most cases. In addition to the samples used for sludge process development testing, samples are being taken at $K$ East Basin in areas where potentially unique local quantities of sludge have either not been previously sampled or where uncharacterized sludge has been mixed with oncecharacterized sludge inventories (e.g., Weasel Pit). While these sludges are expected to be similar to those originally sampled in other locations at $K$ East Basin, the components may be different due to different historic activities performed in those new locations (e.g., Dummy Elevator Pit, Sandfitter Backwash Pit, Tech View Pit). 
Specifically this SAP contains (1) the plan to acquire the sludge samples from the floors and pits of the $K$ West and $K$ East Basins, and (2) the overall requirements for the analytical laboratories to subsample and analyze these samples.

1. Sample Acquisition Activities: Based on the DQ0, which in turn is based on the requirements from the subproject responsible for chemicai treatment of the K Basins sludge (Flament 1998a; Pearce 1998a; Delegard 1998), a sampling campaign including 25 locations has been planned and described in this SAP. The sampling will use two sampling methods: (I) the system previously developed (Baker 1995a) using a "single pull" system to vacuum a sludge core sample into containers and (2) a modified sampling system for shallow areas of sludge, that provides for a continuous suction of sample material and water into a container with the excess water exhausted through a fine filter trapping the sludge sample; the system also allows sampling of two or more similar physical locations into one container ("consolidated" samples). Once the samples are pulled by the single pull core sampler into the special sample containers, they will be transported using PAS-1 casks to the Hanford 222-S or 325 Building laboratories. The selected subset of samples taken using the consolidation sampler will use a container that is transported in a Chem-Nuclear cask to the Hanford 325 Building Laboratory (by trans-shipping through the 327 Building Laboratory pool facility).

2. Plan for Detailed Laboratory Analyses of Samples: The second purpose of this SAP is to provide the specific basic requirements for detailed handling and analysis of the sludge samples after completion of initial acquisition activities noted in the previous paragraph. These 1aboratory requirements form the general scope (i.e., specific laboratory procedures, accuracies, etc.) and criteria (i.e., Quality Assurance, reporting, etc.) for the analyses of the sludge samples. Statements of Work (SOW) will be written to the laboratories to supplement this SAP after the samples are recovered from shipping containers and initial observations are complete. These sows witi provide specific instructions to the laboratories and confirm exactly which samples are to receive particular analyses and any special handling requirements. The final results of the laboratory analyses and their subsequent evaluation, will provide the final documented data satisfying the needs identified by the DQO (Makenas 1998a).

Basic to this sampling campaign are the specific requirements (or needs) the sludge samples address. The DQ0 document (Makenas 1998a, Sections 2.4.2 and 2.7 ) contains this rationale. Additional discussion of these requirements are provided as background in Sections 1.2, 2.1, and 2.2 of this SAP.

The overall status of the past sampling campaigns is provided in Sections 2.1 and 2.2 of this SAP. Additional sampling of sludge in the fuel storage canisters in both basins is planned to follow the floor and pit sludge sampling campaign which is the subject of the present SAP. The sampling of canisters in the future is primarily intended to provide prototypic material for development and design testing activities of the sludge chemical process treatment system or its alternative (e.g., direct disposal of portions of the sludge, etc.). 
HNF-3556, Rev, 0

\subsection{SAMPLING AND ANALYSIS ACTIVITY OBJECTIVE AND GOALS}

The DQO document (Makenas 1998a) for the present activity summarizes the objectives and logic relating the present sampling effort to key Spent Nuclear Fuel (SNF) project activities. The basic decisions requiring these characterization data are related to (1) "does the previously uncharacterized areas of sludge preclude any of the goals of the sludge treatment process to allow disposition of the resulting streams to the TWRS DST and Environmental Remediation Disposal Facility (ERDF)?," (2) "does the proposed sludge treatment process work on a larger scale?," (3) "does fresh sludge (i.e, unoxidized sludge materials versus the current, circa 1995, floor samples that were stored, and in most cases dried) influence the proposed sludge process?," and (4) "do any of the areas of uncharacterized sludge provide constituents or behavior beyond the bounds previously established for recovery, storage, and handling methods to be used at the $K$ Basins to deliver the sludge to the process treatment facility?." The following enlarge on the DQO specified project decisions being addressed by the present sampling campaign in the context of specific goals:

1. What are the physical properties and composition of the $K$ West Basin and $K$ East Basin floor and pit sludge from previously uncharacterized areas that could impact the envisioned goals of the sludge chemical treatment process?

Sampling Goals: Obtain samples of sludge from those uncharacterized areas that are (1) feasible (physically-able) to sample and

(2) contain significant volumes of sludge. The sludge samples will be delivered to the Hanford Analytical Laboratories. Samples from general areas (e.g., single pit, related pit areas, etc.) will be combined where reasonable to form "composite area" samples to maximize the number of basin Tocations sampled for the amount (i.e., cost) of chemical analyses performed. Data on highly local variations are not available using this approach, but this method is consistent with how the sludge is expected to come to the treatment process. Aliquots of the samples will be subjected to physical property testing, chemical analyses, and analyses for selected isotopic composition at the Hanford Analytical Laboratories. These analyses will provide confirming data for design assumptions being used by the SNF sludge subprojects. [Optionally, in addition, scoping process development tests, specific to the current treatment process, may be performed during these analyses for the sludge process treatment subproject if needs are identified and resources are available.]

2. What are the physical and chemical effects on the envisioned sludge process treatment using "fresh" K Basins sludge samples: (1) with minimal aging (i.e., oxidation of components during drying, etc.) or (2) from basin locations where no historic (i.e., 1995) sludge sample material was available for recently completed validation tests for the sludge process treatment?

Sampling Goals: Obtain representative samples of $K$ West Basin and $K$ East Basin floor and pit sludge (including areas previously sampled and analyzed from K East Basin areas). The "sampling goals" as described in the last portion of the prior paragraph follows similarly for this item. 
3. Does the uncharacterized $K$ West Basin and $K$ East Basin floor and pit sludge contain any constituents or combination of constituents that would preclude the use of any processing or treatment alternative that would otherwise be considered as more desirable (i.e., cost effective, timely, ALARA, safer, etc.) than the current chemical treatment process method? It is currently planned to reassess options for. treatment to confirm the chemical treatment method for all sludges is the best choice from an engineering and cost standpoint.

Sampling Goals: Obtain representative samples from uncharacterized areas of the basins. Aliquots will be submitted for analyses to determine chemical and isotopic compositions of selected constituents. Gross physical properties of sludge will also be obtained from the samples (e.g., settled density, volume, weight, settling time, behavior of selected layers, particle size, etc.). This will provide estimates of the analyte concentrations considered of importance to TWRS (e.g., Fowler 1995a, 1995b; Alderman 1997; Wi11iams 1996) and also provide estimates of analyte concentrations important to successful handling of sludge as solid waste (Willis 1993). Additional attributes may need to be addressed if other sludge process alternatives (e.g., grinding, direct disposal to solid waste, etc.) are "down-selected" and prove to be sensitive to parameters other than those of the chemical treatment process.

4. Does the currently proposed sludge treatment process work on large scale applications (hot tests using increased volume over the testing recently completed)? While this large scale process testing is beyond scope of the present DQO and SAP, the present sampling scope does include providing the required quantity of fresh "non-canister" sludge material for all subsequent final validation and large scale hot cell testing of the sludge treatment process.

Sampling Goals: The demonstration of the current chemical process treatment on a 1 arger scale requires the quantities of non-canister sludge anticipated for testing by the sludge treatment process subproject (Makenas 1998a; Delegard 1998). These sample quantities would include fresh sludge from both previously (i.e., 1995) sampled areas and areas not sampled to-date. The material would be sampled from representative locations as defined by the $\mathrm{DQO}$. The samples from the same general areas (e.g., within the same pit, same floor area, etc,) would be combined to form samples representative of larger physical areas (as suggested by the sludge process treatment development subproject staff). Aliquots of the resulting sludge sample material would then be analyzed through a set of basic chemical and physical analyses to provide the basis of their use in a process development testing matrix for large scale process demonstration. Such testing would also consider similarities and differences between the historic (i.e., 1995) sludge sample material and the "fresh" sludge (currently being obtained), in order to relate the results of prior and future testing. 
5. Are the current choices of equipment reasonable to retrieve, handle (e.g., pump, etc.), store, and process sludge within K Basins?

Sampling Goals: Obtain fluid and rheological properties which characterize $K$ West Basin and $K$ East Basin sludges not previousiy sampled to allow accurate development and validation of designs for sludge handling equipment (i.e., transport, processing, filtering, etc.). This goal could also provide required information for developing suitable simulants for equipment development.

6. Can a nondestructive test method, such as portable gamma scanning, provide an acceptable measure of the fissile content or of marker radionuclides consistent with the fissile accountability needs for $K$ Basin floor and pit sludge handling and receipt? (This was not directly addressed in the DQO but is inferred in Table 2.4 of that document under isotopes of europium).

Sampling Goals: Obtain contingent data for the potential development of relationships between fission product radioisotopes (measurable by gamma scan methods translatable to field applications) and plutonium concentration (measured by analytical laboratory methods) in the sludge samples such that, if possible, one or more of the fission products can be identified as a marker for plutonium when quantifying residual transuranics in the sludge. The data for europium isotopes can come from the gamma scan analyses being run for other objectives at essentially "no cost" and collected as a future contingent to respond to this issue.

In addition to the large-scale testing of the sludge treatment process, there will be the need for follow-on verification related to the products of the treatment process being directly demonstrated as acceptable to the receivers of the final waste streams. At this time the two receivers would be (1) TWRS double shell tanks (DSTs)-slated to receive the sludge treatment product stream and (2) ERDF-slated for the solid process waste stream. 
HNF-3556, Rev. 0

\subsection{5-K WEST AND 105-K EAST BASINS STATUS AND SAMPLING INFORMATION}

\subsection{5-K WEST BASIN SLUDGE CHARACTERIZATION STATUS}

The 105-K West Basin was designed and constructed in 1950 to 1951 . The purpose of the basin was to receive and store irradiated fuel from the $K$ West reactor. The basin provided the freshly irradiated fuel with cooling and a 150-day period of time to allow short-lived isotopes to decay. The water in the basin provided the workers with shielding from the nuclear radiation resulting from the isotope decay while they sorted and handled the fuel elements underwater.

The $K$ West reactor stopped the irradiation of fuel in 1971. In 1976, the basins started receiving irradiated $\mathrm{N}$ Reactor fuel from the 105-N Basin. The fuel was stored in the basin in closed twin barreled canisters (Baker 1995a). A portion of this fuel is still stored in the basin today, and some fuel elements have breached cladding such that significant corrosion of the exposed uranium fuel material may have occurred. These corrosion products are primarily hydrolyzed metal and deteriorated fuel compounds that precipitate as a flocculent sediment in the bottom of the canister barrels and may be partially released to the basin when lids are removed. In addition some canisters have lid locking bars that have failed (broken), leaving the barrels "closed" but not necessarily "sealed."

Analyses of sludge in the $K$ West Basin has occurred on (1) sludge sampled from nine selected fuel canisters, (2) small samples of sludge from the Sandfilter Backwash Pit (i.e., North Loadout Pit), (3) subsurface sludge analyzed from under cladding, and (4) trace amounts of sludge that accompanied fuel elements removed from canisters in 1995. Item 1 relates to characterization samples that received extensive analyses (Makenas 1998b). Item 2 relates to periodic cursory operations sampling made on the sludge in the Sandfilter Backwash Pit which contains on the order of $4 \mathrm{~m}^{3}$ of sludge (depths of up to about $1 \mathrm{~m}$ ). Item 3 relates to a series of samples of sludge that were in the shipping container and clung to the fuel elements examined as part of the $K$ Basins fuel element examinations (Makenas 1996c). Because of its possible impact, since it contains about $7 \%$ of the sludge at $K$ Basins, it is noted that the appearance of the uncharacterized sludge in the $K$ West North Loadout Pit (Sandfilter Backwash Pit) appears different than other characterized areas. This is described in Dodd (1995). Observed was a gelatinous behavior associated with the release of large bubbles as the sludge was probed for depth measurements.

As part of the prior $K$ West Basin characterization effort gas and water samples were obtained from a number of the sealed canister barrels. Of concern was the gas composition related to hydrogen, cesium fission products in the water, and the levels of corrosion inhibitor remaining in the canister barrel water. Corrosion inhibitor was injected into the barrels as they were initially closed. The DQO document for the canister siudge characterization effort (Makenas 1998b) provides additional background information. 
The DQO for the present sampling campaign identifies the detailed status of those areas in the $K$ West Basin that have significant volumes of sludge and if they have been characterized. The information is summarized in Table 1 which provides the base objectives of the sampling as prescribed by the DQO. The volumes of the samples address two basic requirements: (1) the need from uncharacterized locations for chemical and physical characterization analyses and (2) the need of specific sludge sample material for use in treatment process development and validation testing.

Table 1. General SampTing Scope Proposed by Data Quality Objectives for Current Sampling (Table 2.3 of Makenas 1998).

\begin{tabular}{||l|c|c|l||}
\hline \multicolumn{1}{|c|}{ Area } & $\begin{array}{c}\text { Number of } \\
\text { Locations }\end{array}$ & $\begin{array}{c}\text { Target } \\
\text { (dry) grams } \\
\text { per Sample }\end{array}$ & \multicolumn{1}{|c|}{ Purpose $^{\prime}$} \\
\hline K East Floor & $4^{2}$ & 400 & Treatment \\
\hline K East Weasel Pit & 2 & $500 \cdot$ & Treatment \\
\hline K East North Loadout Pit & 2 & 350 & Treatment \\
\hline K East Dummy Elevator Pjt & 2 & 300 & Characterization and Treatment \\
\hline K East Tech View Pit & 2 & 200 & Characterization and Treatment \\
\hline$K$ West Floor & 5 & 100 & Characterization and Treatment \\
\hline$K$ West North Loadout Pit & $5^{3}$ & 200 & Characterization and Treatment \\
\hline$K$ West Tech View Pit & $2^{3}$ & 200 & Characterization and Treatment \\
\hline$K$ West Dummy Elevator Pit & 1 & 200 & Characterization and Treatment \\
\hline Total & 25 & 6400 & Characterization and Treatment \\
\hline
\end{tabular}

'Treatment implies the material will be used for process studies. Characterization implies the samples address a here-to-for uncharacterized area of sludge.

${ }^{2}$ Includes one sample with intentionally large concentration of resin beads.

${ }^{3}$ Samples spread between main pit and transfer channel.

\subsection{5-K EAST BASIN SLUDGE CHARACTERIZATION STATUS}

$K$ East Basin has a general operating history similar to that noted for $K$ West Basin. The differences between the basins are: (1) K East Basin was the first of the two put into operation for $N$ fuel storage, (2) the fuel storage canisters have no lids, (3) and the fuel is in a much more degraded condition. The canister barrels in some instances also have slotted sides and open bottoms that can leak much of the canister sludge as they are moved in the basin during normal handling, Figure 1. The basin itself is uncoated concrete, as opposed to $\mathrm{K}$ West Basin where the basin was drained and coated to 


\section{HNF-3556, Rev. 0 BEST AVAILABLE COPY}

Figure 1. Sludge Escaping Out Screened Holes in the Bottom of K East Basin Canister During Typical Move.

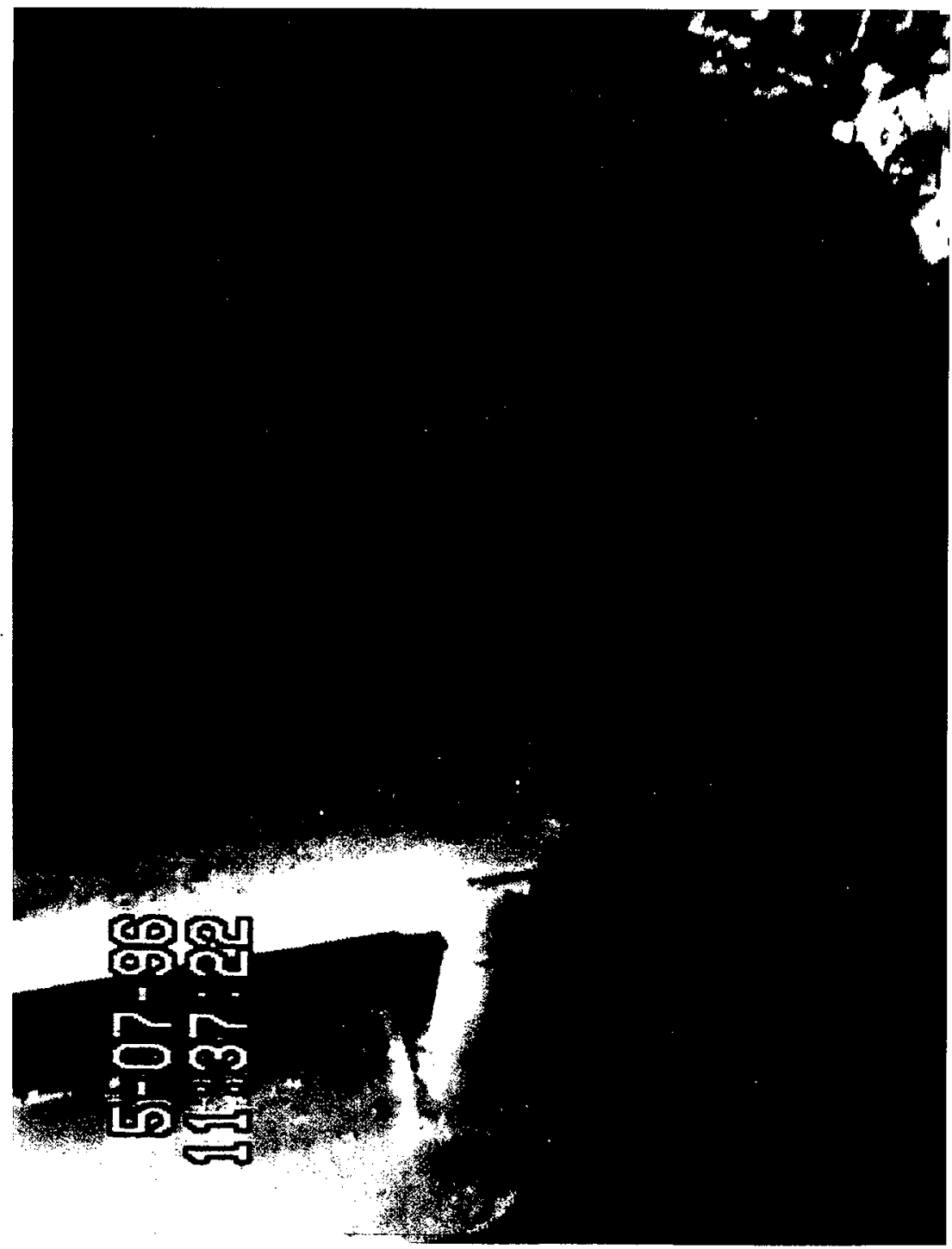


HNF-3556, Rev. 0

seal the concrete prior to the current storage mission. As noted in the DQO and in Appendix $A$, the $K$ East Basin contains signifjcantly more sludge on its floor and in the pits than $K$ West Basin (about $50 \mathrm{~m}^{3} \mathrm{~K}$ East versus $7 \mathrm{~m}^{3}$ K West).

The $K$ East Basin main basin floor and Weasel Pit sludges were recently characterized, based on 20 samples taken in 1995 (Makenas 1996c). In addition nine. (9) samples of sludge from $K$ East Basin fuel storage canisters were subsequently taken in 1997 (Makenas 1996b). The nine canister samples were taken to compare the mean property measurement values from the canister sludge to those of the floor/pit sludge. The K East Basin floor sludge was also periodically sampled prior to 1995 (Baker 1995b). The analytical results have indicated the floor sludge material to contain predominantly sands, ferric oxides, aluminum oxides, and uranium oxide residuals. The sludge has also been found to contain trace amounts of barium, cadmium, chromium, lead, and samarium. Some sludge samples from the floor, Weasel Pit, and canisters showed the presence of polychlorinated biphenyls (PCBs). Samples from the canisters also showed sludge samples generated gas both in some of the shipping containers and during the settling studies. These samples contained very high concentrations of fuel (e.g., uranium concentrations in dry canister sludge was high as $65 \mathrm{wt} \%$ ). The gas formed in the K East canister sludge was found to be hydrogen with traces of fission gases and tritium. This Teads to the conclusion that unreacted uranium metal fuel could be present, however no such metal fuel was detected in the samples analyzed by X-Ray diffraction (XRD). This lack of confirmation may result from there only being a comparatively few particles of uranium or that the particles are quickly coated with an oxide layer masking the uranium metaI from the XRD analysis.

The sludge in the 105-K East Basin Sand Filter Backwash Pit (SFBWP) and its transfer channel have been sampled periodically by operations to monitor fissile inventory buildup and a special sampling effort was completed in 1994 related to a safety issue (Bechtold 1994; Baker 1995b).

The most recent overall set of measurements of floor sludge depths in the 105-K East Basin main basin were completed in 1994 and have shown that the basin floor is covered with sludge to a depth of $5 \mathrm{~cm}$ to $19 \mathrm{~cm}$ (Baker 1995a) and that the Weasel Pit is covered with sludge up to a meter or more in depth (Makenas 1996c), see Appendix B, Figure B1. Potential local sources of sludge that could influence the floor sludge characterization were evaluated by the Spent Nuclear Fuel Characterization Project organization (SNFCP) at that time (Baker 1995b). The local sources (besides the environmental sand, insects, etc.) considered were:

- Fuel sludge passing through openings in canisters containing breached fuet elements

- Corrosion of the aluminum canisters

- Sloughing of the unsealed concrete walls that form the basin

- Flaking paint off the fuel storage racks

- Historical activities (e.g., fuel handling, IXM maintenance, etc.) affecting areas near the mouth of the pits (i.e., Wease] Pit, Tech View Pit, Dummy Elevator Pit, North Loadout Pit, and South Loadout Pit). 
As noted earlier, detailed sampling and analyses for the floor sludge in the $K$ East Basin main basin and Wease1 Pit (Makenas 1996c) agreed with expectations, with the exception of the unexpected identification of PCBs in some of the sludge samples and the quantity of IXM beads found in certain locations.

The DQO for the present sampling campaign identifies the detailed status of those basin areas that have significant volumes of sludge and have not been characterized in the original detailed sampling campaign in 1995. The primary reason these were not sampled at that time was because of physical debris obstructed sampling; in some cases these locations can now be sampled. Several other areas sampled in 1995 or 1994 now either have significant new sludge added to the area (i.e., Weasel Pit) or did not have a full compliment of characterization analyses run on them (i.e., Sandfilter Backwash Pit). Finally, because almost all the sludge samples from the prior floor and pit characterization campaign have been depleted during sludge treatment process testing, more material is required for the validation tests from the general basin floor area and Weasel Pit. The information summarized in Table 1 provides the base objectives of the sampling as prescribed by the DQO. As with the $K$ West Basin sampling, the volumes of the samples in $K$ East Basin address the two primary objectives: (1) the need of sludge from areas yet uncharacterized so chemical and physical characterization analyses can be made and $(2)$ the need of the sludge treatment process development subproject related to development and validation testing.

\subsection{SAMPLING INFORMATION}

\subsubsection{Sample Collection and Handling}

The sampling at $K$ Basins will be conducted such that the operation does not impact the water quality/air emissions. The sampling apparatus is described in Baker (1998b and 1995c). Two similar systems will be used to acquire samples. The first, the "single pull" sludge core sampler, is the same equipment used for the $1995 \mathrm{~K}$ East Basin floor sampling campaign, Figure 2. It utilizes a metal tube (or pipe) to isolate representative core samples of the sludge material on the floor of the main basin and in remote pits. This core is vacuumed into a set of special 4 liter sample bottles on the basin grating above. The sampling team will follow approved sampling procedures during the collection of the samples. Detailed descriptions of the sampling apparatus and methodology will be provided in the sampling procedure (K Basins OP-43-031E [KE] and OP-43-032W [KW]) and Project Work Plan (K Basin PWP-98-001).

The second sampling system, Figure 3, the "consolidated sampler," is similar to the first except it is designed to collect sludge samples from areas where the layer of sludge is relatively shallow and does not provide enough depth for reasonable core sampling (e.g., depths less than about $0.4 \mathrm{in.)}$. This sampler uses a similar nozzle system, but collects a sample into a 10 liter, underwater container (similar to that used for canister sludge sampling, Makenas 1998b). The system does a continuous draw of 
Figure 2. Overview of the Sludge Core or Primary Floor Sampling Equipment.
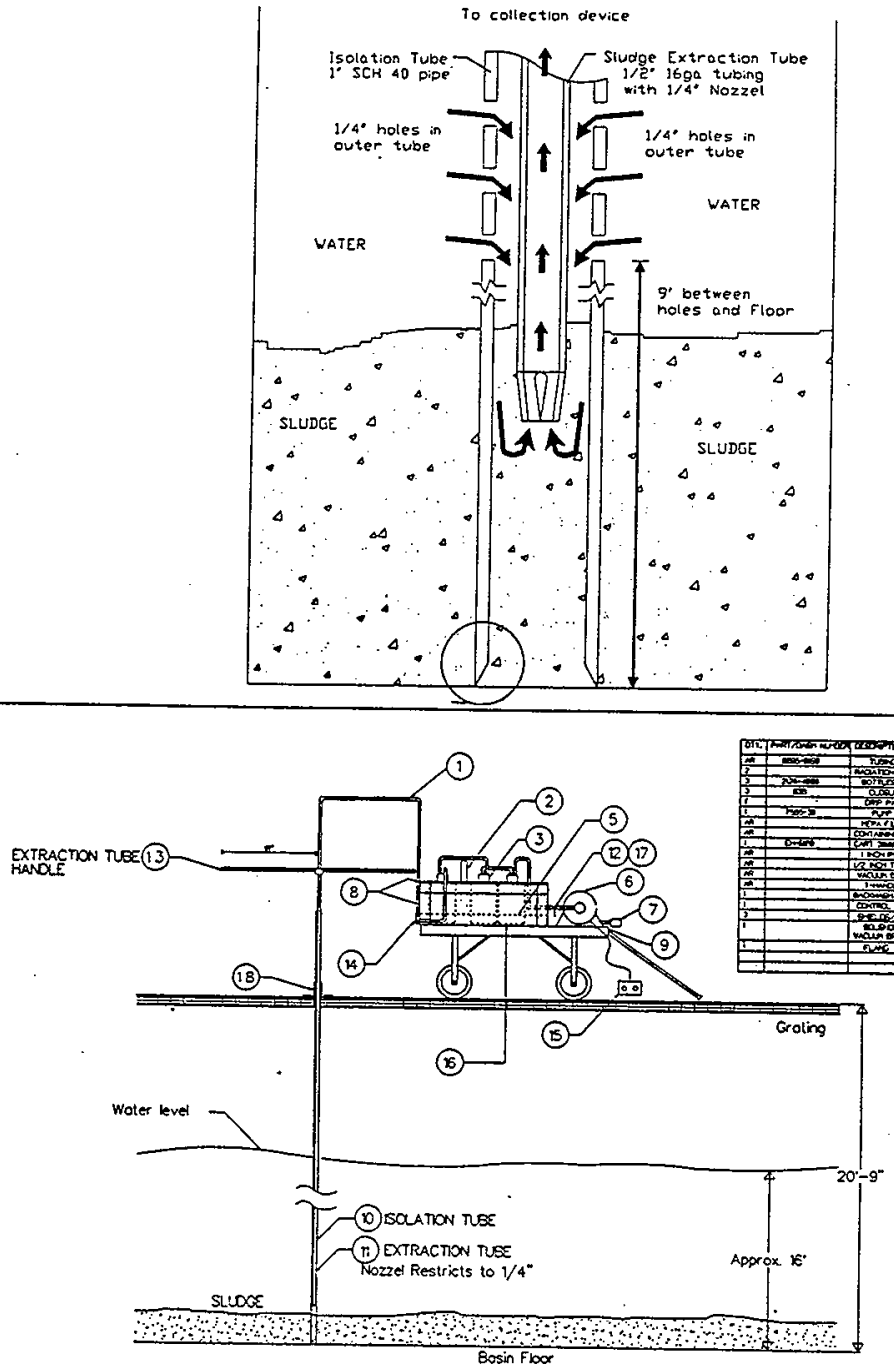
HNF-3556, Rev. 0

Figure 3. Overview of the Consolidated Floor Sludge Sampling Equipment.

\section{LAYOUT/SCHEMATIC CONSOILDATED SAMPLER}

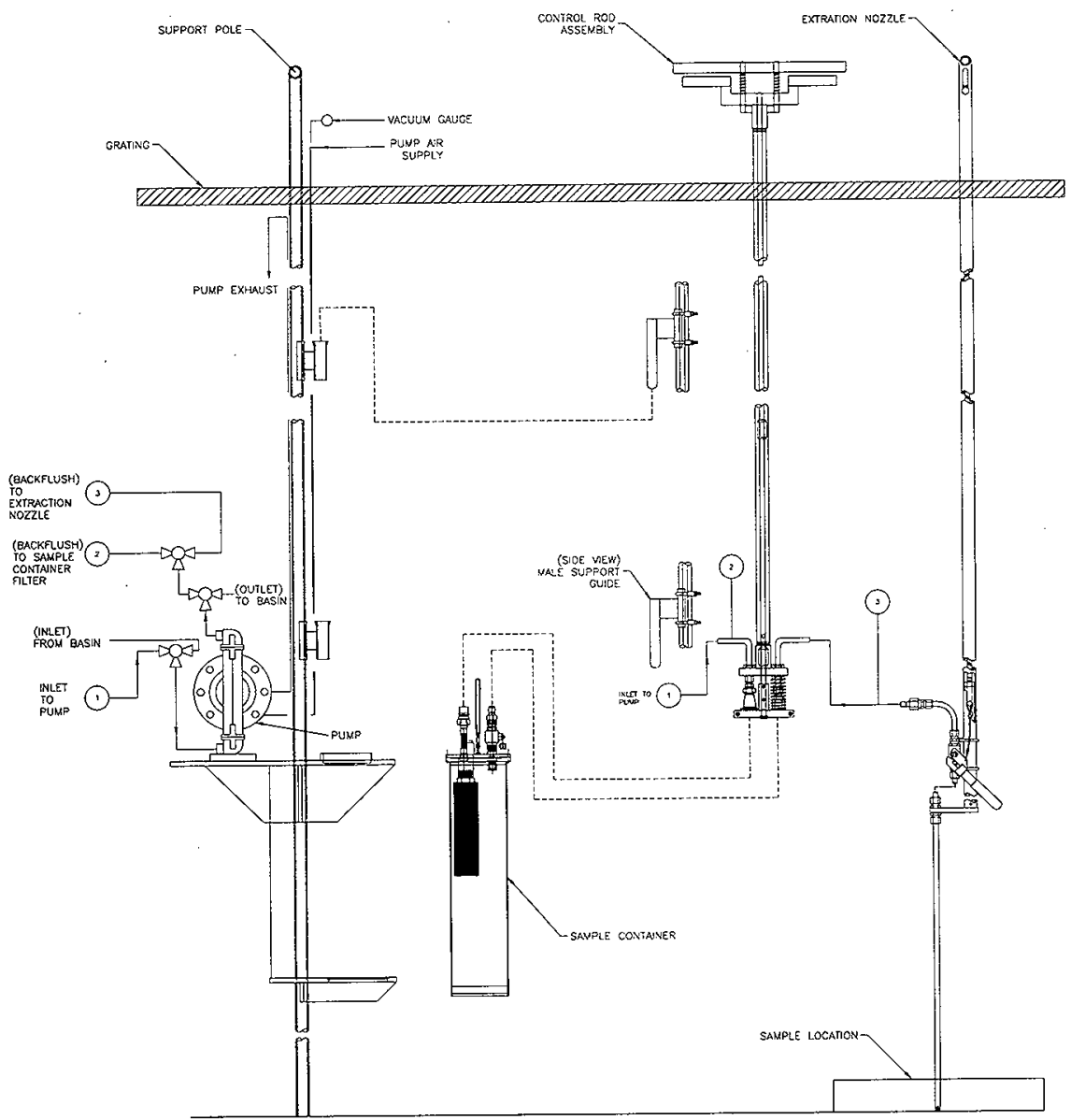

$0 / 41321.000$ 
material through a fine (e.g., 5 micron) filter, exhausting the filtered water back into the basin pool. Thus, the sampler is expected to capture most particles greater than 5 microns and a portion of those 5 microns or less. The prior floor and canister sludge samplers pull directly into containers, retaining all water and material, that is no filters are used and no water or material is exhausted back to basin (i.e., "single pull"). This was done to assure minimal change in the physical properties of the sludge sample pulled. For the subject shallow depth sludge samples it was judged much more important to obtain significant volumes of material for analysis and testing than the concern for the effects of the filter on physical properties and minor loss of very fine particles.

Each sludge sample container will be labeled or marked with a unique sample number. The SNFCP organization Test Engineer shail verify to ensure the samples are properly identified and the sample location recorded prior to moving the sample from the $K$ Basins area. The SNFCP organization Test Engineer will ensure that the sample custody during transportation will be tracked at all times by "chain-of-custody" protocol, resulting in documented traceability.

After the sludge core or "single pul1" samples have been collected into the sample bottles, they will be loaded in the PAS-1 Cask containers per $K$ Basin procedure OP-43-016 "Load and Ship K Basin Sludge Samples in PAS-1 Cask." For the consolidated sampler containers, similar logic will be used based on procedures currently being developed. The containers in this case will be moved from $K$ Basins to the 327 Building facility using the Chem Nuclear cask (instead of the PAS-1 casks), and from there to the 325 Building Laboratory using a Hanford 300 Area inter-building cask.

It is the intent of this SAP to ship the samples to the analytical laboratory within a week of when they are collected. If logistics preclude shipment within one week from the date of sampling, the SNFCP organization Project Coordinator will evaluate the situation to provide applicable storage for the samples. The consolidated sampler containers may be stored at the $K$ Basins in the pool for a longer period of time (i.e., 1 month or more). In the basin pools these containers remain in an environment (i.e., temperature, chemistry, etc.) similar to the sludge under general basin conditions, so the stored samples should maintain their integrity.

Once the sludge samples arrive at the laboratories they will be stored and handled to avoid evaporation as much as possible. Because chemical preservation steps do not make allowance for slurries and would adversely affect the sample ( $\mathrm{pH}$ change), chemical preservation of samples will not be performed. It should be noted that since hydrogen gas generation has occurred in the canister sludge samples, safety precautions are required in sealing any small containers in laboratories and hot cells.

As in the past campaigns, it is planned that the analytical laboratories will dispose of the remains of the sludge and water samples after the anaiyses and sludge treatment process development tests are completed. If it is found beneficial, and the operations groups at $K$ Basins concur, decanted water may be returned to the $K$ Basins from the laboratories. 
HNF-3556, Rev. 0

\subsubsection{Sample Record Keeping}

A vital part of the sampling activity is the assurance that all of the information and data associated with each sample are accurate and verifiable. Therefore, all pertinent information and data collected during the sampling sample breakdown, analyses and reporting will be recorded. The pertinent data to be collected and the corresponding records will be maintained in accordance with the requirements of the sampling procedure ( $K$ Basins $O P-43-031 E$ and $0 P-43-032 \mathrm{~W})$, and the $Q A$ at the 1 aboratory doing the sample breakdown, analysis and reporting (see Section 8.0). Chain of custody (COC) forms will be used at each step of collection and transfer by field and laboratory personnel (i.e., required in $\mathrm{K}$ Basin Project Work Plan, etc). The SOWs for the sampling effort may also provide additional direction on record keeping.

\subsubsection{Field Sample Plan Modifications}

Any modifications to the sludge sampling plan made in the field must be made/approved by the SNFCP organization Test Engineer and/or SNFCP Project coordinator and documented. Changes affecting quality related information will include QA approval.

\subsubsection{Basis and Locations of Sampling}

Samples will be taken from locations consistent with the DQO (Makenas 1998a). In addition to the general DQ0 criteria, the selection process also considered: (1) accessibility of the areas by the sampling crew at the basins, (2) possible disruption of the base sludge layers by recent operation and construction activities, and (3) current safety restrictions at the basins. As in past sampling campaigns, a criterion was used to sample in reasonably accessible locations (i.e., sampling through grating slots--no grating removal, sampling around debris--no major debris removal, and sampling around operation obstructions--not removing current restrictions around floor drain valves, etc.). Using these criteria were judged to have no significant impacts on the quality of the samples with respect to their use. This follows since the sludge within the areas being sampled is expected to be uniformly deposited across these areas due to the expected dispersion of the material through the pool of water.

Tables 2 and 3 define the samples and corresponding intended locations. In two locations, the total number of samples taken was changed slightly from the $\mathrm{DQO}$. Target versus projected sludge volumes are noted in Table 4 . One of the two samples to be taken in the K East Basin Tech View Pit was deleted because it was not possible, in the very shallow sludge found present, to get a reasonable quantity of material that would warrant two core samples. Correspondingly, a sample was added to the $K$ East Basin main floor area that will be taken between the barrels of a canister with damaged fuel to provide additional data (only one such sample was taken in 1995 campaign, "KES-0-09"). Such data are of concern to sludge treatment process subproject for evaluating the alternative of recovering the $K$ East Basin floor sludge, grouting it, and sending it directly to solid waste. One of the five samples indicated in the 
Table 2. Floor and Pit Sludge Sampling Locations.

\begin{tabular}{|c|c|c|}
\hline Location & $\begin{array}{c}\text { Sample } \\
\text { Location } \\
\text { Identification }\end{array}$ & Specific Sample Location Information \\
\hline \multicolumn{3}{|l|}{ (1) Bastin } \\
\hline Main/East Bay & $\mathrm{KW}-(1)-\mathrm{Cl}$ & Deepest area of this bay $(0.1 \mathrm{in}$. see SD-TI-054). \\
\hline Main/Central Bay & $\mathrm{KW}-(2)-\mathrm{Cl}$ & $\begin{array}{l}\text { Deepest area in this bay }(0.1 \text { in. see SD-TI-054). Consolidate during } \\
\text { sampling with } \mathrm{KW}-(1)-\mathrm{Cl} \text {. }\end{array}$ \\
\hline Main/West Bay-North & $\mathrm{KW}-(3)-\mathrm{C} 2$ & $\begin{array}{l}\text { Deepest area in NW corner of this bay }(0.271 \text { in. see SD-T1-054). } \\
\text { Consolidate during sampling with } \mathrm{KW}-(5)-\mathrm{C} 2 \text {. }\end{array}$ \\
\hline Main/West Bay-Center & $K W-4$ & $\begin{array}{l}\text { Core sample from deepest position in bay/main basin. Near center of } \\
\text { West wall, } 0.68 \text { in., see SD-TI-054. }\end{array}$ \\
\hline Main/West Bay-South & $\mathrm{KW}-(5)-\mathrm{C} 2$ & $\begin{array}{l}\text { Deepest area in SW corner of bay ( } 0.4 \text { in. see SD-TI-054). Consol idate } \\
\text { during sampling with } \mathrm{KW}-(3)-\mathrm{C} 2 \text {. }\end{array}$ \\
\hline North Loadout Pit-1 & $K W-6$ & Center of Northwest open area beyond restriction in main pit. \\
\hline North Loadout Pit-2 & $\mathrm{KW}-7$ & Center of Southwest open area beyond restriction in main pit. \\
\hline North Loadout Pit Trs-1 & $\mathrm{KW}-8$ & Center of West half of transfer channel. \\
\hline North Loadout Pit Trs-2 & KW-9 & Center of East half of transfer channel. \\
\hline Dumy Elevator Pit & $\mathrm{KW}-(10)-\mathrm{C3}$ & Deepest area in pit, consolidate during sampling with $K W-(12)-C 3$. \\
\hline $\begin{array}{l}\text { Tech View Pit South } \\
\text { Channel }\end{array}$ & $K E-11$ & Deepest area in Tech View South trans channel, best effort. \\
\hline Tech View Pit Main & $\mathrm{KE}-(12)-\mathrm{C} 3$ & $\begin{array}{l}\text { Deepest area in main pit }(0.11 \text { in., see SD-TI-054). Consolidate during } \\
\text { sampling with } \mathrm{XW}-(10)-C 3 \text {. }\end{array}$ \\
\hline \multicolumn{3}{|l|}{ AEBas } \\
\hline Main/East Bay & KE-1 & Cubical 0168 South side, similar to KES-K-12 location. \\
\hline Main/East Bay-South & $\mathrm{KE}-2$ & Cubical 1065 North side. \\
\hline Main/West Bay-IXM & KE-3 & Same as KES-H-08 location, cubical 6755 only North side, deepest area. \\
\hline Main/West Bay & $\mathrm{KE}-4$ & Cubical 6722 North side, similar to KES-1-15. \\
\hline North Loadout Pit & KE-5 & Middle unrestricted area of main pit. \\
\hline North Loadout Pit Trs & $\mathrm{KE}-6$ & Middle of transfer channel. \\
\hline Durmy Elevator Pit-1 & $\mathrm{KE}-7$ & Best effort middle of East half of pit. \\
\hline Dummy Elevator Pit-2 & $\mathrm{KE}-8$ & Best effort middle of West half of pit. \\
\hline Weasel Pit-East & KE-9 & Midway between where KES-R-18 and KES-S- 19 were taken. \\
\hline Weasel Pit-West & KE-10 & Midway between where KES-P-16 and KES-Q-17 were taken. \\
\hline $\begin{array}{l}\text { Tech View Pit North } \\
\text { Channel }\end{array}$ & $\mathrm{XE}-11$ & North channel midway between doors, along South wall, deepest sludge. \\
\hline Main Basin East-1XM-2 & $\mathrm{KE}-12$ & $\begin{array}{l}\text { Second IXM main floor sample, cubical } 6756 \text { to deepest area, similar to } \\
\text { KES-H-08. }\end{array}$ \\
\hline Between Barrels & $\mathrm{KE}-13$ & Cubical 4573 , between barrels of slotted canister with damaged fuel. \\
\hline
\end{tabular}

Note: The KES samples are from 1995 sampling, see WHC-SP-1182. 
Table 3. Summary of $K$ Basins Floor and Pit Sludge Sampling Projections.

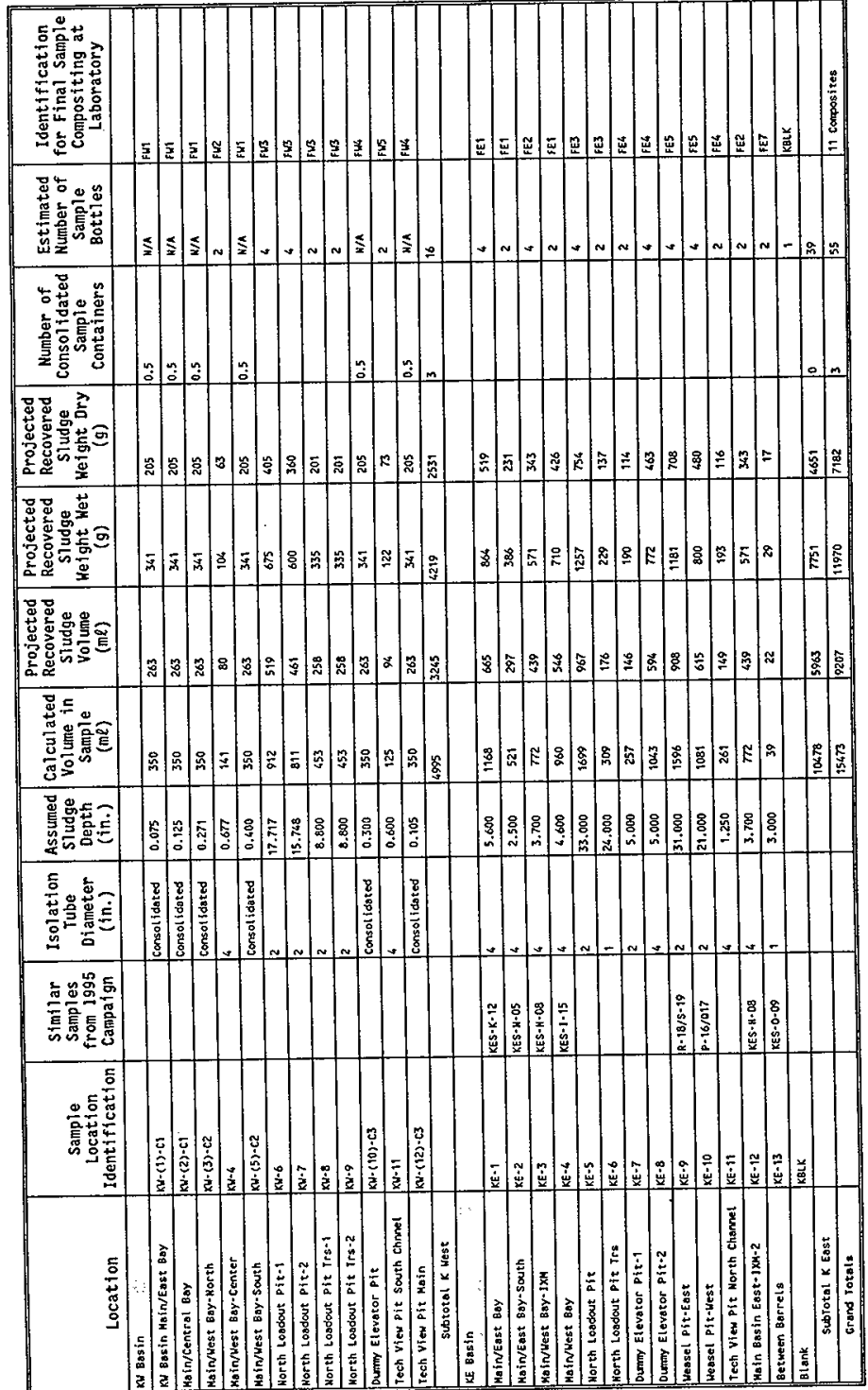


HNF-3556, Rev. 0

Table 4. Overall Comparison of Proposed Targets from Data Quality Objectives to Present Sampling Projections for K East and K West Floor and Pit Sludge.

\begin{tabular}{|c|c|c|c|c|c|c|c|c|}
\hline & \multicolumn{5}{|c|}{ DQO } & \multicolumn{3}{|c|}{ SAP } \\
\hline & $\begin{array}{l}\text { Number of } \\
\text { SampTe } \\
\text { Locations }\end{array}$ & $\begin{array}{c}\text { Target } \\
\text { Dry } \\
\text { Weight } \\
\text { per } \\
\text { Location } \\
\text { (g) }\end{array}$ & $\begin{array}{c}\text { Target } \\
\text { Total } \\
\text { Dry } \\
\text { Weight } \\
\text { per Area } \\
\text { (g) }\end{array}$ & $\begin{array}{c}\text { Target } \\
\text { Total As- } \\
\text { Settied } \\
\text { Weight } \\
\text { (g) }\end{array}$ & $\begin{array}{c}\text { Target } \\
\text { Total } \\
\text { Volume } \\
\text { As- } \\
\text { Settled } \\
\text { (ml) }\end{array}$ & $\begin{array}{c}\text { Calculated } \\
\text { Total } \\
\text { Recovered } \\
\text { Volume } \\
\text { As-Settled } \\
(\mathrm{m} \ell)\end{array}$ & $\begin{array}{l}\text { Calculated } \\
\text { Total } \\
\text { Sludge Dry } \\
\text { Weight } \\
\text { (me) }\end{array}$ & $\begin{array}{l}\text { Number of } \\
\text { Sample } \\
\text { Locations }\end{array}$ \\
\hline KE Floor & 3 & 400 & 1200 & 2000 & 1538 & 1530 & 1193 & 4 \\
\hline $\begin{array}{l}\text { KE Floor, } \\
\text { IXM }\end{array}$ & 1 & 400 & 400 & 667 & 513 & 878 & 685 & 2 \\
\hline $\begin{array}{l}\text { KE Weasel } \\
\text { Pit }\end{array}$ & 2 & 500 & 1000 & 1667 & 1282 & 1523 & 1188 & 2 \\
\hline $\begin{array}{l}\text { KE North } \\
\text { Loadout Pit }\end{array}$ & 2 & 350 & 700 & 1167 & 897 & 1143 & 891 & 2 \\
\hline $\begin{array}{l}\text { KE Dummy } \\
\text { Elevator } \\
\text { Pit }\end{array}$ & 2 & 300 & 600 & 1000 & 769 & 740 & 577 & 2 \\
\hline $\begin{array}{l}\text { KE Tech } \\
\text { View Pit } \\
\end{array}$ & 2 & 200 & 400 & 667 & 513 & 148 & 116 & 1 \\
\hline KW Floor & 5 & 100 & 500 & 833 & 641 & 1130 & 882 & 5 \\
\hline $\begin{array}{l}\text { KW North } \\
\text { Loadout Pit }\end{array}$ & 5 & 200 & 1000 & 1667 & 1282 & 1496 & 1167 & 4 \\
\hline $\begin{array}{l}\text { KW Tech } \\
\text { View Pit } \\
\end{array}$ & 2 & 200 & 400 & 667 & 513 & 356 & 278 & 2 \\
\hline $\begin{array}{l}\text { KW Dummy } \\
\text { Elevator } \\
\text { Pit }\end{array}$ & 1 & 200 & 200 & 333 & 256 & 263 & 205 & 1 \\
\hline Total & 25 & & 6400 & 10667 & 8205 & 9208 & 7182 & 25 \\
\hline
\end{tabular}

Notes: Assumed conversion factors:

Density $\mathrm{g} / \mathrm{m} \ell$ as-settled

Factor from wet to dry

1.3

Recovery factor cores

0.6

Recovery factor consolidated

0.57 (based partially on 1995 , total recovery to laboratory)

0.75 Estimate 
HNF-3556, Rev. 0

DQ0 for the $K$ West Basin North Loadout Pit was deleted. This was done because sufficient volume of material could be obtained from four samples (conserving resources) and four samples was judged sufficient to characterize the limited area accessible.

To maximize the number of locations sampled within the resources available, sampling is planned at 25 locations but this material will be composited into 12 samples prior to starting detailed analyses in the laboratories. The DQO calls for not combining material from different pits. This was followed except for very shallow areas. Here it was judged much more advantageous to obtain a composite than have to ignore the area because of resources precluding so many analyses. Further, the only such composite (from $K$ West Dummy Elevator Pit and Tech View Pit) is from pit areas that are in open communication (i.e., no doors or screens in between) with the main basin.

The conversion factors and constants used throughout the present SAP for sludge density; relating wet and dry sludge; and expected recovery factors for the samples is provided in the notes of Table 4 . These are based on past experience from sampling floor sludge in K East Basin (Makenas 1996c).

Sludge depths in Table 3 are based on the historic data (K East Basin measurements made in 1994 and 1995, K West Basin measurements made in 1997). Operations at $K$ Basin may have affected sludge depths noted here and current actual depths could vary. As sludge samples are taken during the campaign the sludge depths of the sampled area will be confirmed using the scales provided on the outside of the isolation tubes used in the core sampler or measured with an auxiliary measurement scale when the consolidated sampler is used. Generally, it is intended to take samples where local area depths of sludge are greatest (reflecting the greatest amounts of material in the basins). It will be an option for the SNFCP Test Engineer to move the location of a sample in a specific area if the sludge depth appears more appropriate at a nearby location. Final sampling locations will be documented in the logbook and video taping will be performed as samples are taken. As with prior campaigns (e.g., Makenas 1996c) the final evaluation report for these sampling activities will document the locations and condition of the sludge in the areas sampled.

$K$ West Basin--Twelve sample locations, Figure 4, were selected from $K$ West Basin, Tables 2 and 3 . Six of these will be taken with the primary floor sludge sampling device using the isolation tubes to isolate cores of sludge (i.e., single pull core sampler). Six locations will be sampled with the consolidated sampling equipment (because of the comparatively shallow depth of sludge in these areas). With the consolidation sampler the sludge from two similar physical locations in the basin will be drawn into a single sampling container (i.e., they will be consolidated), see Section 2.5.1. For the $K$ West Basin campaign this will result in three consolidated sample containers containing the material from the six $K$ West Basin and open pit locations. See Tables 5 and 6 for summary of which sampler is being used to draw specific samples.

Main Basin Floor: Samples will be drawn from five locations, Figure 4, of the main basin floor at $K$ West Basin. Figure B1 of Appendix $B$ indicates the depths involved, based on measurements made in 


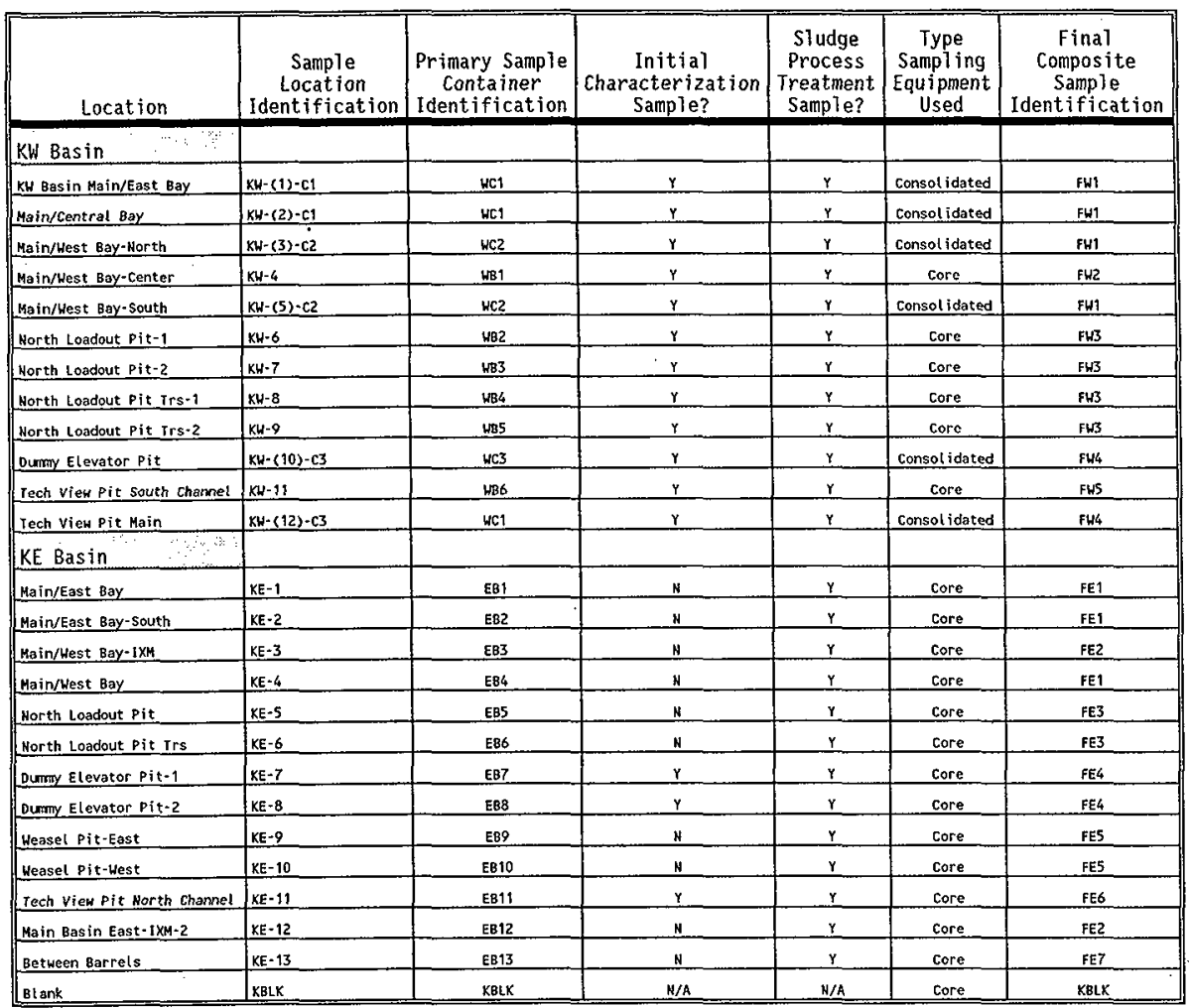


Table 6. Summary of Composited Samples.

\begin{tabular}{|c|c|c|c|}
\hline Sample Type & $\begin{array}{c}\text { Sample } \\
\text { Designation }\end{array}$ & $\begin{array}{c}\text { Primary Samples Used to } \\
\text { Make Composite }\end{array}$ & Area Represented \\
\hline \multicolumn{4}{|c|}{ Core sludge Sampler } \\
\hline Normal & FW2 & $\mathrm{KW}-4$ & KW deepest floor \\
\hline Research & FW3 & $\mathrm{KW}-6, \mathrm{KW}-7, \mathrm{KW}-8, \mathrm{KW}-9$ & $\begin{array}{l}\text { KW North loadout pit and } \\
\text { channel }\end{array}$ \\
\hline Normal & FW5 & $\mathrm{KW}-11$ & KW tech view pit \\
\hline Normal & FE1 & $K E-1, K E-2, K E-4$ & KE floor, general \\
\hline Norma] & FE2 & KE-3, KE-12 & KE floor, IXM beads \\
\hline Research & FE3 & $K E-5, K E-6$ & $\begin{array}{l}\text { KE North loadout pit and } \\
\text { channel }\end{array}$ \\
\hline Normal & FE4 & $\mathrm{KE}-7, \mathrm{KE}-8$ & KE dummy elevator pit \\
\hline Normal & FE5 & KE-9, KE-10 & KE weasel pit \\
\hline Normal & FE6 & KE-11 & KE Tech view pit \\
\hline Normal & FE7 & $K E-13$ & $\begin{array}{l}\text { KE floor between slotted } \\
\text { barrels with damaged fuel }\end{array}$ \\
\hline Normal & KBLK & Equipment blank water & KE equipment water sample \\
\hline \multicolumn{4}{|c|}{ Consolidated STudge Sampler } \\
\hline Norma 1 & FW1 & $\begin{array}{l}\mathrm{KW}-(1)-\mathrm{C} 1, \mathrm{KW}-(2)-\mathrm{Cl}, \\
\mathrm{KW}-(3)-\mathrm{C} 2, \mathrm{KW}-(5)-\mathrm{C} 2\end{array}$ & $\begin{array}{l}\text { KW floor, East bay and } \\
\text { Center bay }\end{array}$ \\
\hline Norma] & FW5 & $\mathrm{KW}-(10)-\mathrm{C} 3, \mathrm{KW}-(12)-\mathrm{C} 3$ & $\begin{array}{l}\text { KW dummy elevator pit and } \\
\text { tech view pit }\end{array}$ \\
\hline
\end{tabular}


Figure 4. K West Basin Floor and Pit Sample Locations.

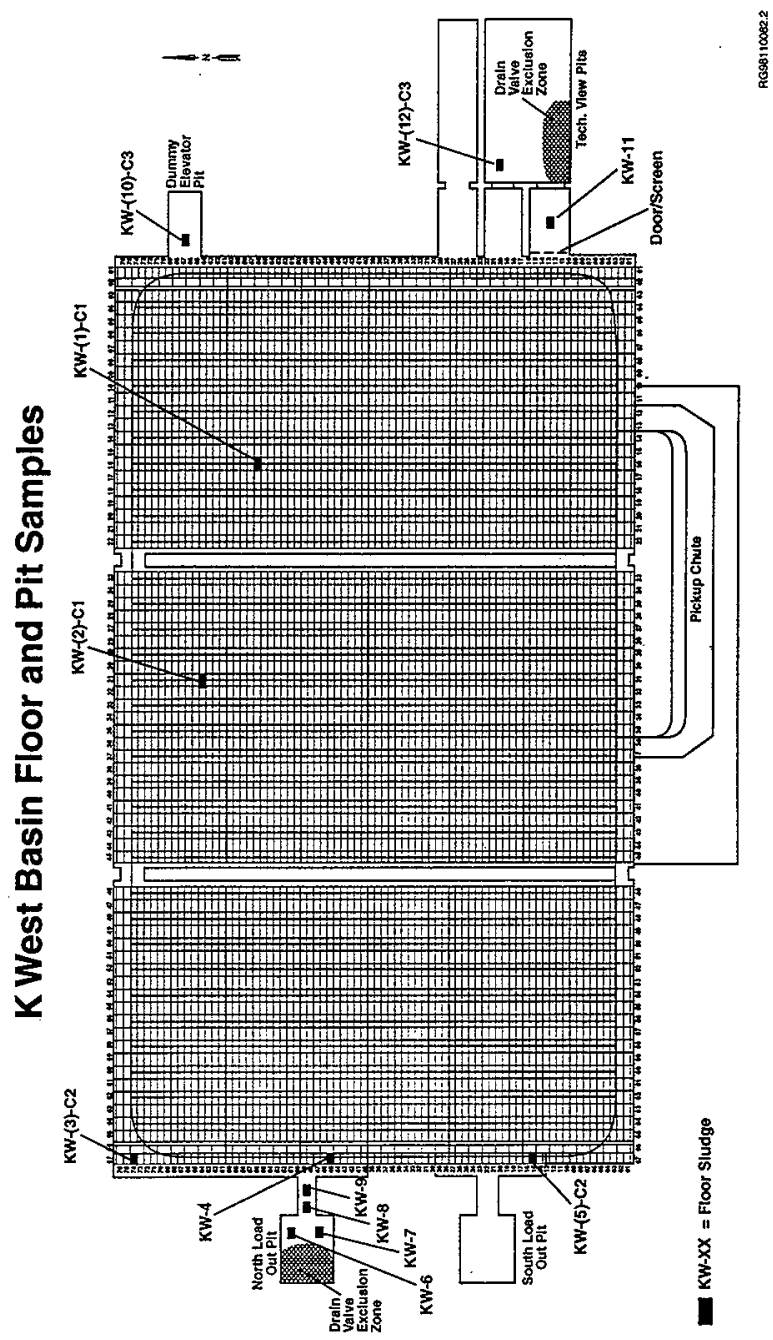


HNF-3556, Rev. 0

1997 (Maassen 1997). The consolidated sampling equipment will be used to draw two approximately $350 \mathrm{~m} \ell$ (i.e., original wet sample volume) samples of sludge from one location in the East Bay and one in the Central Bay, into a single sample container. These locations were selected because they are the deepest observed (Maassen 1997) in these bays with very shallow sludge depths. The West Bay was observed to have deeper areas of sludge than the East and Central Bays. A second consoljidated sample container will be used to draw similar quantities of sludge from two locations in the West Bay, one from the Northwest and one from the Southwest areas. These samples will be representative of two of the deeper (though still comparatively shallow) areas in the main basin. The consolidated sample target volumes were intentionally made larger than required by $\mathrm{DQO}$ to provide for contingency during sample recovery in the 1aboratory.

Finally, a fifth location will be sampled in the main basin using the primary (i.e., core) sampling device, drawing a sample using the largest diameter isolation tube (i.e., 4 in. diameter). This sample will be taken at the location in the West Bay where the sludge is indicated to be the deepest on the main floor (Maassen 1997) see Figure B1. It is intended that this sample provide any required data on slurry rheology properties for the main basin floor sludge, since it will have the material most representative for this type characterization (versus the consolidated sampler material that may not include a portion of the population of very fine, less than 5 microns, particle sizes). The combination of using the consolidated sampler to provide the two larger volume samples from four areas (primarily to support pretreatment process development) and one core sample (to provide a base check using single pul1 sample material) provides for the intended sampling objectives.

North Loadout (or Sandfilter Backwash) Pit: The North Loadout Pit will have a total of four samples taken from it, Figure B2. Sludge in this pit has not been previously characterized, see Section 2.1 , and it represents the greatest volume of sludge in. K West Basin, Appendix $A$. Sludge depth measurements, Figure B3, for this pit were reported by Dodd (1995). Routine operations have taken very small dilute samples of sludge to characterize potential fissile material inventory changes as backflushes have occurred. For the present characterization campaign two samples will be taken from the transfer channel; dividing the channel into a front (East) half and a back (West) half then taking samples near the middle of these areas. Two samples will be taken from the main pit area; spanning the available open area outside the floor drain valve restricted area, (a $6 \mathrm{ft}$ radius circle encompassing the floor drain valves, see Figure B2). The primary intent is to collect sufficient sludge material for sludge treatment process development testing, since it is not expected that there will be significant variation in the sludge composition across the pit because of the way the material is backflushed into the pit with large volumes of water. However, it is expected that the sludge composition will vary by depth. To provide some spacial variation indicator, and since a limited number of sizes of isolation tubes are available, two samples are being taken in the relatively small area of the main pit. 
South Loadout Pit: The sludge in the South Loadout Pit was pumped to the South Channel of the Tech View Pit in 1997, see Appendix A.

Dummy Elevator Pit and Tech View Pit: The Dummy Elevator Pit has an estimated siudge volume of only $1.4 \mathrm{ft}^{3}$, with a maximum estimated depth of 0.3 in. (Maassen 1997). The Tech View Pit also has a relatively small quantity of sludge, total of $2.4 \mathrm{ft}^{3}$. It was judged it would be adequate for these pits to use one consolidated sample including: approximately $350 \mathrm{~m} \ell$ of sludge from the deepest location in the Dummy Elevator Pit and a similar quantity from the deepest location in the main pit of the Tech View Pit. While the DQO recommended that sludge samples from different pits not be combined, in the case of these two "open" (to the main basin) pit areas with only shallow quantities of sludge, it was judged more important to obtain some information and significant material from both areas than potentially eliminating one due to resource constraints. Because the consolidated sampler equipment cannot be used in the South Channel of the Tech View Pit (area is screened off from main basin) a core sample is being taken in this shallow area. Figures B4 and B5 provide the sampling locations and Figure B1 provides selected sludge depths for reference.

Weasel Pit and Discharge Chute: It was judged with a maximum observed depth of 0.1 in., Figure B1, that neither of these relatively small areas warrant sampling (Makenas 1998a).

K East Basin--In K East Basin 13 samples will be taken, Figure 5 . A11 the samples being taken in $K$ East Basin will be drawn with the primary (i.e., core) floor sludge sampler.

Main Basin Floor: Cubicle locations in two of the three bays were selected for sampling based on sludge depth and past sampling locations, Figure 5. The sample locations were generally chosen from the deeper areas, Figure B6, so the sum of the samples represent the largest quantities of sludge on the K East Basin floor. Similarly, general locations to those used in prior (Figure B7) campaigns (i.e., opposite sides of the same empty cubicals sampled in 1995) were chosen in several cases; this was done to better assure accessibility and provide some linkage of the sludge from prior analysis results to the current material. Two samples, KE-3 and KE-12 were chosen specifically to provide samples with a high percentage (e.g., 75\%) of IXM beads, similar to sample KES-H-08 from the sampling made in 1995. These samples with beads seek to provide the quantity identified in DQO as well as providing, on a best effort basis, some additional material for testing as identified in Delegard (1998) as needed.

Sample KE-13 was selected, as requested by the sludge treatment process development subproject staff, to be between the barrels of a canister with damaged fuel. This will provide a second data point under these conditions (one taken in 1995, "KES-0-09"). KE-13 is being taken from the floor in the Center Bay. The overall volume of sludge in this bay is less than the other two bays and a portion (i.e., the central area) of the sludge originally located in this bay was pumped to the Weasel Pit after 1995. Therefore, the two samples to come from the Weasel Pit in the present campaign should include some material from this bay. 
Figure 5. K East Basin Floor and Pit Samples.

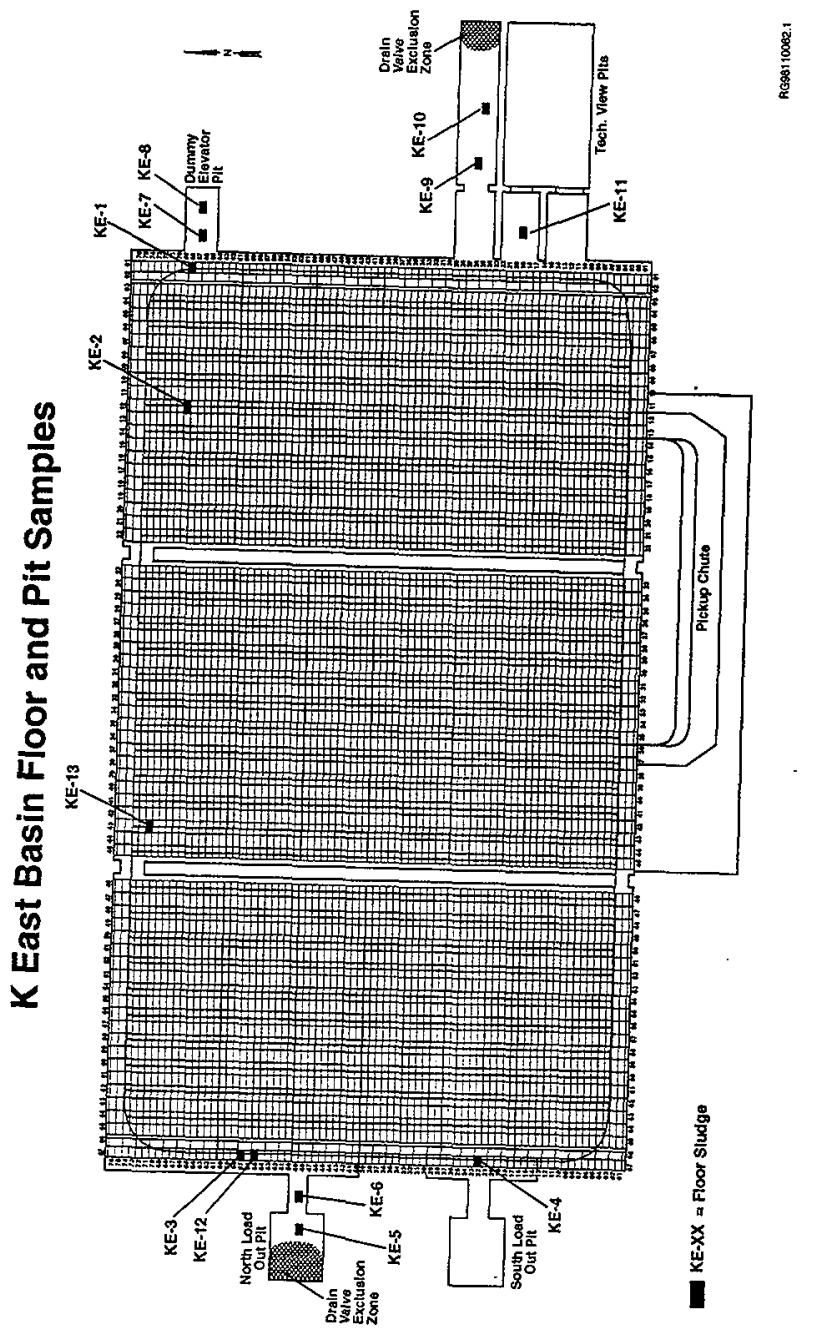


HNF-3556, Rev. 0

North Loadout Pit: A sample will be drawn from the center of the nonrestricted area of the main pit of the North Loadout Pit. A second sample will be taken from the transfer channel near jts center, Figures B8 and B9. These samples are primarily to provide material for the sludge treatment process development. Since the material in these areas should be reasonably mixed as backflushes are made of the sandfilter, only a single sample from each general location is required.

South Loadout Pit and Discharge Chute: No significant sludge remains in the South Loadout Pit or the Discharge Chute. The South Loadout Pit sludge was pumped to the Weasel Pit after 1995. The Discharge Chute was pumped to the Weasel Pit prior to the 1995 sampling campaign (We]sh 1995).

Dummy Elevator Pit: The Dummy Elevator Pit was not sampled during the 1995 sampling campaign because there was too much debris in it to allow access to the floor by the sampling equipment. Some of the debris has now been removed and significant sludge is projected to reside in the pit (though this has not been directly measured, Appendix A). Two samples will be taken from the Dummy Elevator Pit on a "best effort" basis (there is still significant debris) during the present sampling campaign. One sample will be attempted near the center of the East half of the pit and one in the West half of the pjt, Figure Blo.

Wease 1 Pit: Since the 1995 characterization campaign the Weasel Pit has had sludge from the South Loadout Pit and the center area of the Center Bay added to it. Figure Bll indicates the sludge depths in 1995 and Figure B12 the sample locations used in 1995. For the current sampling campaign of the Weasel Pit two samples will be taken, Figure B13. One sample will be taken between the location of the samples designated KES-Q-17 and KES-P-18 in the 1995 campaign, and similarly the second sample will be taken between the locations of the KES-S-19 and KES-R-18 samples. Because harder layers were encountered at different depths during the 1995 sampling of this pit (Makenas 1996c), it is planned that the particular locations previously sampled will be avoided during the current sampling to better ensure representative core samples are obtained (i.e., from undisturbed areas).

Tech View Pit: The Tech View Pit sludge was not sampled in the 1995 campaign. One sample will be drawn during the current campaign. This will be located, Figure B13, where the deeper area of sludge was observed previously in the North Channel (Baker 1995a).

\subsubsection{Sample Recovery, Final Compositing, and Preparation at Hot Laboratory}

Procedure(s) or test instructions for the recovery of the sample material from the shipping containers (i.e., either 4 liter bottles or 10 liter sludge containers) and subsequent sample preparation and handling will be prepared by the designated Hanford Laboratory. These procedures will be similar to those used for the K East Basin floor sludge samples (Bechtold 1994). The sample preparation and handling procedure will contain the detailed instructions 
HNF-3556, Rev. 0

necessary to safely and properly record observations, monitor, settle, decant and subsample (as needed), digest (if necessary), handle, package, and label each sample and its derivatives in the hot cell/hood. The SNFCP organization Project Coordinator will concur with the procedures or test instructions prior to their application.

For the present floor and pit sludge sampling campaign, it is planned to combine or composite sample material from similar basin locations (e.g., same floor area, same pit, etc.) prior to initiating the detailed analyses or use of the sample sludge materials for testing. In the case of the samples coming from the primary (i.e., core) sampler, this means combining the sludge sample materials from several locations together into a single initial container (e.g., combining sludge from sample bottles from several locations into a graduated cylinder) at the laboratory hot cell. Then proceeding with subsequent characterization analyses and pretreatment testing from this composite sample. In the case of the consolidated sampler the sludge sample material will be combined as it is collected from the two or three basin locations sampled. Therefore, the material need only be removed from the sample container and transferred to laboratory container to begin analyses (e.g., settling, etc.). Tables 3,5, and 6 show the samples that are currently planned for compositing, this may be revised in the SOWs if the condition of the actual sample material recovered warrants a different approach.

Samples will be designated either "normal" or "research" after settling, the handling of the "normal" and "research" samples differ in that the research samples witl be separated for analyses of individual layers. A "normal" sample will be homogenized and analyses will be performed on the integrated properties. The "research" samples will be separated into major "layers" and each layer analyzed. This is necessary for meaningful rheology measurements and is of interest for possible impact of settled layers behaving differently than the mixed mass of the sample (e.g., plutonium concentration). Layers will be identified as was done for the prior $K$ East Basin floor sludge samples--that is a visual identification by color and/or texture of regions of sludge material appearing as stratum after settling studies are completed. Typically two or three layers were found in the $K$ East Basin sludge samples. Table 5 indicate those samples initially selected for research samples, however, this selection could be revised in subsequent SOWs after the material has gone through settling studies.

Analysis of all the siudge samples by layers was considered. It was, however, concluded the limited number of research samples would be sufficient. Factors involved in this decision (not analyzing by layers in all samples) included: the sludge feed streams will be mixed during recovery and transport to the sludge treatment equipment, the difficulty in objectively determining layers, settling differences between the evolving material in the basin versus using all the material at once in the analytical laboratory, a desire to maintain the maximum sample quantity to minimize potential for inhomogeneities when splitting, and lack of objective data concerning the distribution of the heavier components. The research samples were chosen from the North Loadout Pit because these represent the largest volumes of sludge that have not been characterized related to fluid properties and information on layering (such as densities). 
Subsamples for organics analyses and other analyses affected by either drying or acid digestion (TIC, TOC, TC, DSC, IC, XRD, etc.) need to be obtained prior to sample preparation.

In some cases, as specified in subsequent SOWs, the liquid portion and the wet sludge should be sampled for the various analyses. Table 7 indicates the condition of the sample material for the various analyses.

It is very important that the analytical laboratories measure and record the evolving densities (i.e., volumes and weights) of the sludge samples (i.e., as-settled, centrifuged, partially dried, dried, etc.). These densities will allow both comparison to past work and the state of sludge as collected. 
Table 7. Proposed Responsible Laboratory and Sample Condition for the Floor and Pit Sludge Samples.

\begin{tabular}{|c|c|c|c|c|}
\hline Analysis ${ }^{1}$ & $\begin{array}{c}\text { Proposed } \\
\text { Laboratory }\end{array}$ & $\begin{array}{c}\text { Acceptable } \\
\text { to Acid } \\
\text { Digest ? }\end{array}$ & $\begin{array}{c}\text { Acceptable } \\
\text { to Dry? }\end{array}$ & Comments \\
\hline $\begin{array}{l}\text { Rad-Chemistry } \\
\text { Pu Isotopes } \\
{ }^{341} \mathrm{Am}, 245 / 244 \\
\text { U Total } \\
\text { U Isotopes } \\
\text { GEA } \\
\text { Total Alpha } \\
\text { Tota1 Beta } \\
{ }^{99} \mathrm{TC},{ }^{00} \mathrm{Sr},{ }^{237} \mathrm{~Np} \\
\end{array}$ & $\begin{array}{l}222-S \\
222-S \\
222-S \\
325 \\
222-S \\
222-S \\
222-S \\
222-S \\
\end{array}$ & $\begin{array}{l}\text { Yes } \\
\text { Yes } \\
\text { Yes } \\
\text { Yes } \\
\text { Yes } \\
\text { Yes } \\
\text { Yes } \\
\text { Yes } \\
\end{array}$ & $\begin{array}{l}\text { Yes } \\
\text { Yes } \\
\text { Yes } \\
\text { Yes } \\
\text { Yes } \\
\text { Yes } \\
\text { Yes } \\
\text { Yes }\end{array}$ & $\begin{array}{l}{ }^{238} \mathrm{Pu},{ }^{239 / 240} \mathrm{Pu} \\
{ }^{233} \mathrm{U},{ }^{234} \mathrm{U},{ }^{235} \mathrm{U},{ }^{236} \mathrm{U},{ }^{238} \mathrm{U} \\
\mathrm{V}, \mathrm{Cs}, \text { and Eu Isotopes }\end{array}$ \\
\hline $\begin{array}{l}\text { General Chemistry } \\
\text { ICP Metals } \\
\text { IC IOns } \\
\text { TOC/TIC/TC } \\
\text { SVOA/PCB } \\
\text { pH } \\
\text { Caustic Demand } \\
\end{array}$ & $\begin{array}{l}222-S \\
222-S \\
222-S \\
325 \\
222-S \\
222-S \\
\end{array}$ & $\begin{array}{l}\text { Yes } \\
\text { No } \\
\text { No } \\
\text { No } \\
\text { No } \\
\text { No } \\
\end{array}$ & $\begin{array}{l}\text { Yes } \\
\text { No } \\
\text { No } \\
\text { No } \\
\text { No } \\
\text { No } \\
\end{array}$ & \\
\hline $\begin{array}{l}\text { Physical Properties } \\
\text { Settling Rate } \\
\text { Appearance } \\
\text { Viscosity } \\
\text { Density }(\rho) \\
\text { Settled } \\
\text { Dry Particle } \\
\text { XRD } \\
\text { Pyrophoric Material } \\
\text { Residuals (digest) } \\
\text { Particle Size } \\
\text { Particle Shape } \\
\text { Zeta Potential }\end{array}$ & $\begin{array}{l}325 \\
325 \\
325 \\
325 \\
325 \\
325 \\
\\
325 \\
325 \\
325 \\
325 \\
325\end{array}$ & $\begin{array}{l}\text { No } \\
\text { No } \\
\text { No } \\
\text { No } \\
\text { No } \\
\text { No } \\
\\
\text { No } \\
\text { No } \\
\text { No } \\
\text { No } \\
\text { No }\end{array}$ & $\begin{array}{l}\text { No } \\
\text { No } \\
\text { No } \\
\text { No } \\
\text { No } \\
\text { No } \\
\text { Yes } \\
\text { Yes } \\
\text { No } \\
\text { No } \\
\text { No }\end{array}$ & Report Full Curves \\
\hline$\frac{\text { Thermal Properties }}{\text { TGA/DSC }}$ & 325 & No & No & Report Fu17 Thermogram \\
\hline Process Testing Samples & $325,222-5$ & No & No & \\
\hline
\end{tabular}

${ }^{1}$ Some sludge materials have PCB levels that may require a TSCA permit for further process testing.

${ }^{2} 222-5$ is the Hanford 222-S Laboratory facility, 325 is the Hanford/PNNL 325 Building Radiochemistry Process Development Laboratory.

${ }^{3}$ Shipping between laboratories may require 325 Building to run selected radiochemistry to support shipment ${ }^{4}$ Report
${ }^{236} \mathrm{Pu},{ }^{259} \mathrm{Pu},{ }^{240} \mathrm{Pu}$, and ${ }^{241} \mathrm{Pu}$ if generated as part of other analyses. 
HNF-3556, Rev. 0

This page intentionally left blank. 
HNF-3556, Rev. 0

\subsection{LABORATORY ANALYSIS INSTRUCTIONS}

\subsection{GENERAL}

Specific instructions on processing of each sludge sample and composite sludge samples in the analytical laboratories will be provided by Statements of Work (SOW) from the SNFCP organization prior to shipment of samples or after the observation of the recovered samples. For shipping subsamples between laboratories sludge samples may be analyzed initially to ascertain properties such as fissile and fission product content for criticality, shielding and accountability.

Each sludge shipping container (ejther 4 liter bottle or 10 liter container) will be received by the analytical laboratories. The sludge samples will then be recovered from the shipping containers and prepared for settling studies, Section 2.3.5. Certain samples will be combined to provide composites, either as indicated in Tables 5 and 6 , or as directed by subsequent Sows. During the settling studies, any observations of gas generation from the sludge material should be immediately noted to the SNFCP organization. If significant, an evaluation will be conducted to determine if gas monitoring is required. High resolution video taping will be made of samples during settling studies and if gas generation is observed.

Selected sludge physical properties (e.g., settling rate, density, etc.) wil1 be obtained prior to any subsampling efforts. Other properties (such as viscosity and particle size/shape) must be determined from aliquots taken prior to any other preparation steps. Prior to heating or acid digestion, aliquots of both the liquid and the solids will be obtained from the appropriate samples. These aliquots will be used by the laboratories for organic, TIC, TOC, XRD, DSC, TGA, and other analyses sensitive to either drying or acid digestion. An aliquot of the thoroughly stirred dried sludge, of sufficient weight to minimize sample heterogeneity, will then be processed through an acid digest procedure. An aliquot of the acid digested sludge shall be prepared and sent to the laboratory. Any residual solids which remain after the acid digestion step will be analyzed by XRD. If there is a sufficient quantity the residuals will also be subjected to caustic fusion and further ICP, radiochemistry, and XRD analyses. The acid digest (i.e., hot plate and beaker) used will be the same as that previously used for the K East Basin canister sludge analyses (Makenas 1997) or as specified in subsequent sows. The general condition of the sample for the different analyses is provided in Table 7 .

The laboratory will analyze each aliquot in duplicate or as directed in Section 8.0 of the present SAP or subsequent SOWs. Each subsample taken from that aliquot must go through separate sample preparation, if sample preparation is required. If a sufficient amount of dried sludge is not available for the acid digestion step, then analyses for that sample may be limited to higher priority data. The laboratory should subsequently document the reason for not performing any of the analyses called for in the sow in the narrative of their data report. An alternative to not performing the analyses is to have K Basin Operations take additional samples for the "other" 
required analyses. The choice of not performing analyses or requesting additional samples will be at the discretion of the SNFCP organization Project Coordinator.

A flowchart showing the general analysis scheme for the sludge samples in the laboratory is presented in Figure 6 . The analytical tests for the analytical laboratory work are shown in Table 8 . The reason or need for each of these analyses is defined in the DQO (Makenas 1998a). In general the samples designated as "normal" will receive all the analyses in Table 9 with the exception of those related to rheology measurements. The "research" samples will be split into samples of the observed layers or strata, and these will each in general receive all the analyses in Tables 8 and 9 including rheology measurements (also see Sections 2.3 .5 and 3.1 ).

Note that no analyses for waste designation are called for in the DQO (see Section 2.2 of that document). This follows directly from the assumption made by the SNF Project for $K$ Basin sludge that the waste designation will be made based on "process knowledge." As discussed in the DQO document, pyrophoricity of the sludge is being assessed from the XRD measurements for metallic zirconium, metallic uranium, and uranium hydrides. Exothermic reactions may be evaluated by differential scanning calorimetry (DSC).

An additional objective of this sampling campaign is to provide representative sludge material to the $K$ Basin sludge treatment process development subproject testing activities. Any material not directiy used for characterization analyses will be kept as much as possible in an "as-collected" state during any storage in the hot cells and shipping activities. The material should not be allowed to dry out (oxidizing some materials and causing physical changes), be mixed with non-prototypic materials (e.g., de-ionized water, etc.) or subjected to extremes in environment (i.e, higher than room temperatures, high $\mathrm{pH}$, contact with potentially contaminating surfaces, etc.). The disposition of the sample material will be the subject of a SOW after the samples are obtained and initially observed. This SOW will provide more direction on storage environment requirements. The actual testing and analyses related to sludge process development testing itself will be covered under separate Sows from the sludge treatment process subproject. The exception to this is for scoping process testing done with the initial samples in direct cooperation with the sludge treatment process subproject, in order to improve the economics of the overall project.

\subsection{ANALYSES}

Table 9 shows the analytes, methods, and the laboratory procedures required for the analysis of the samples. The table also lists the requirements for detection levels, precision, and accuracy of data results. Note that if dilution factors change from what is expected based on factors from the $1995 \mathrm{~K}$ East Basin floor sludge sampling (Miller 1995), the detection levels, precision, and accuracy values shown in Table 9 will have to be re-evaluated. The SNFCP Project Coordinator will be notified of the condition and a decision will be made and documented on how to proceed. One reagent blank will be run if required by the laboratory procedure for each analytical 
HNF-3556, Rev. 0

Table 8. 105-K West and K East Basins Floor and Pit Sludge Analyses.

\begin{tabular}{|c|c|c|}
\hline Requested Analysis & Analysis Technique & Constituents to be Reported \\
\hline $\begin{array}{l}\text { Am-Isotopic } \\
\text { Pu-Isotopic }\end{array}$ & Separation and AEA & ${ }^{2431 / 244} \mathrm{Am}{ }^{238} \mathrm{Pu},{ }^{239 / 240} \mathrm{Pu}$, and \\
\hline Sr-90 & $\begin{array}{l}\text { Separation and beta } \\
\text { counting }\end{array}$ & ${ }^{90} \mathrm{Sr}$ \\
\hline $\mathrm{Np}-237$ & $\begin{array}{l}\text { Extraction and aTpha } \\
\text { counting }\end{array}$ & ${ }^{237} \mathrm{~Np}$ \\
\hline Total Gamma & GEA & $\begin{array}{l}{ }^{241} \mathrm{Am},{ }^{134} \mathrm{Cs},{ }^{137} \mathrm{Cs},{ }^{60} \mathrm{Co},{ }^{152} \mathrm{Eu},{ }^{154} \mathrm{Eu}, \\
\\
155 \mathrm{Eu},{ }^{212} \mathrm{Bi},{ }^{208} \mathrm{Tl},{ }^{125} \mathrm{Sb},{ }^{226} \mathrm{Ra},{ }^{95} \mathrm{Nb}, \\
\mathrm{Ru} / \mathrm{Rh} \text { and }{ }^{144} \mathrm{Ce} / \mathrm{Pr} \text { and other gamma } \\
\text { emitters in Tibrary }\end{array}$ \\
\hline Gross Alpha & $\begin{array}{l}\text { Gas proportional } \\
\text { counting }\end{array}$ & Detectable alpha emitters \\
\hline Gross Beta & $\begin{array}{l}\text { Gas proportional } \\
\text { counting }\end{array}$ & Detectable beta emitters \\
\hline U Total & $\begin{array}{l}\text { Laser fluorescence or } \\
\text { phosphorescence }\end{array}$ & Total uranium \\
\hline U Isotopics & TIMS & $\begin{array}{l}{ }^{233} \mathrm{U},{ }^{234} \mathrm{U},{ }^{235} \mathrm{U},{ }^{236} \mathrm{U}{ }^{238} \mathrm{U},{ }^{23} \text { a so report } \\
\text { avai i able data on }{ }^{236} \mathrm{Pu},{ }^{239} \mathrm{Pu},{ }^{240} \mathrm{Pu}, \\
\left.\text { and }{ }^{241} \mathrm{Pu}\right)\end{array}$ \\
\hline Metals & ICP & $\begin{array}{l}\mathrm{Al}, \mathrm{Cd}, \mathrm{Sm}, \mathrm{B}, \mathrm{Fe}, \mathrm{Ba}, \mathrm{Cr}, \mathrm{Pb}, \mathrm{Ag}, \\
\mathrm{Be}, \mathrm{Tl}, \mathrm{Zn}, \mathrm{Cu}, \mathrm{Mn}, \mathrm{Mg}, \mathrm{Ca}, \mathrm{Na}, \mathrm{K} \text {, } \\
\mathrm{Se}, \mathrm{U}, \mathrm{Zr}, \mathrm{Bi}, \mathrm{P} \text {, and } \mathrm{Ni} \text { ( } \mathrm{Hf}, \mathrm{Sn} \text { if } \\
\text { in current suite of analyses) }\end{array}$ \\
\hline IC Analyses & IC & $\mathrm{PO}_{4}^{3-}, \mathrm{SO}_{4}^{2-}, \mathrm{F}^{-}, \mathrm{Cl}^{-}, \mathrm{Br}^{-}$ \\
\hline TC-99 & $\begin{array}{l}\text { Solvent extraction } \\
\text { with liquid } \\
\text { scintillation counter }\end{array}$ & ${ }^{99} \mathrm{Tc}$ \\
\hline Organics & SVOA & Any TICs found in the analysis, \\
\hline $\begin{array}{l}\text { Endothermic/Exothermic } \\
\text { Reactions (Optional) }\end{array}$ & $\begin{array}{l}\text { DSC/TGA (use TWRS } \\
\text { method with nitrogen } \\
\text { and air cover gas) }\end{array}$ & DSC/TGA include annotated thermogram \\
\hline Settling Rate & $\begin{array}{l}\text { Settling columns and } \\
\text { video camera }\end{array}$ & $\begin{array}{l}\text { Volume settled versus time, video } \\
\text { tape }\end{array}$ \\
\hline
\end{tabular}


HNF-3556, Rev. 0

Table 8. 105-K West and K East Basins Floor and Pit Sludge Analyses. (Continued)

\begin{tabular}{|c|c|c|}
\hline Requested Analysis & Analys is Technique & Constituents to be Reported \\
\hline $\begin{array}{l}\text { Polychlorinated } \\
\text { Biphenyls (PCB) }\end{array}$ & $\begin{array}{l}\text { PCB as near EPA } \\
\text { methods as reasonable }\end{array}$ & $\begin{array}{l}\text { PCB concentration in indicated solids } \\
(1 \mathrm{ppm}) \text { and water }(0.2 \mathrm{ppb})\end{array}$ \\
\hline Settled Densities & $\begin{array}{l}\text { Gravimetric/sample } \\
\text { preparation procedure }\end{array}$ & Settled density, volume, and weight \\
\hline Residual from Digest & $\begin{array}{l}\text { Gravimetric/sampie } \\
\text { preparation procedure }\end{array}$ & $\begin{array}{l}\text { Weight percent of original material } \\
\text { left after acid digest (wet and dry) }\end{array}$ \\
\hline Residuai Analysis & $\mathrm{XRD}$ & $\begin{array}{l}\text { Qualitative analysis of any } \\
\text { undigestible residue }\end{array}$ \\
\hline Pyrophoricity & XRD & $\begin{array}{l}\text { Qualitative analysis of the sludge } \\
\text { prior to heating or digestion. } \\
\text { Unreacted metallic uranium and } \\
\text { Zr; unoxidized uranium hydride; } \\
\text { uranium oxide; hydrates of } \mathrm{Al}_{2} \mathrm{O}_{3} \text {, } \\
\mathrm{UO}_{2+} \text { and } \mathrm{FeO}_{x}\end{array}$ \\
\hline $\begin{array}{l}\text { Particle Size } \\
\text { Distribution }\end{array}$ & $\begin{array}{l}\text { Particle size } \\
\text { analyzer and sieves }\end{array}$ & Size, distribution \\
\hline Particle Shape & $\begin{array}{l}\text { Optical microscopy, } \\
\text { SEM, or TEM }\end{array}$ & Shape \\
\hline Particie Density & $\begin{array}{l}\text { Gas pycnometer/ } \\
\text { calculation }\end{array}$ & Density dry/density wet \\
\hline Viscosity & Viscometer & Viscosity \\
\hline $\mathrm{TIC} / \mathrm{TOC} / \mathrm{TC}$ & $\begin{array}{l}\text { Persulfate oxidation } \\
\text { and coulometry }\end{array}$ & TIC $\left(\mathrm{CO}_{3}{ }^{2-}\right)$, TOC, TC \\
\hline Zeta Potential & Zeta plus instrument & $\mathrm{mV}$ \\
\hline $\begin{array}{l}\text { Caustic Demand } \\
\text { (Optional) }\end{array}$ & $\begin{array}{l}\text { Potentiometric } \\
\text { titration }\end{array}$ & Buffering capacity \\
\hline $\begin{array}{l}\text { Gas Generation from } \\
\text { Settlers (Optional) }\end{array}$ & $\begin{array}{l}\text { Capture measured } \\
\text { volume of gas over } \\
\text { specific time and } \\
\text { analyze for } \\
\text { composition }\end{array}$ & $\begin{array}{l}\text { Rate of gas volume generated (as a } \\
\text { function of hours), composition of } \\
\text { gas released, and temperature of } \\
\text { sludge sample }\end{array}$ \\
\hline pH & pH probe & pH units \\
\hline Cyanide & Standard methods & Cyanide concentration \\
\hline
\end{tabular}


HNF-3556, Rev. 0

Table 9. Analytical Requirements for the 105-K West and East Basins Floor and Pit Sludge Samples (222-S and 325 Laboratories). (Continued)

\begin{tabular}{|c|c|c|c|c|c|}
\hline Process & Constituents & Procedure & Required $\mathrm{MDL}^{1}$ & Precision ${ }^{2}$ & Accuracy $^{3}$ \\
\hline \multicolumn{6}{|l|}{ Separation, AEA } \\
\hline & ${ }^{238} \mathrm{Pu}$ & $\begin{array}{l}\text { LA-953-104 } \\
\text { PNL-ALO- } \\
417 / 496 / 422\end{array}$ & $8.0 \mu \mathrm{Ci} / \mathrm{g}$ & $\pm 20 \%$ & -- \\
\hline & ${ }^{239 / 240} \mathrm{Pu}$ & $\begin{array}{l}\text { LA-953-104 } \\
\text { PNL-ALO- } \\
417 / 496 / 422\end{array}$ & $3.0 \mu \mathrm{Ci} / \mathrm{g}$ & $\pm 20 \%$ & $\pm 25 \% \mathrm{Sp}$ \\
\hline & ${ }^{243 / 244} \mathrm{Am}$ & $\begin{array}{l}\text { LA-953-104 } \\
\text { PNL-ALO- } \\
417 / 496 / 422\end{array}$ & $\begin{array}{l}15.0 \mu \mathrm{Ci} / \mathrm{g} \\
15.0 \mu \mathrm{Ci} / \mathrm{g}\end{array}$ & $\pm 20 \%$ & $\begin{array}{l} \pm 25 \% \text { Sp } \\
\text { Am only }\end{array}$ \\
\hline $\begin{array}{l}\text { Phosphorescence or } \\
\text { Fluorimetric }\end{array}$ & $U$ total & $\begin{array}{l}\text { LA-925-009 } \\
\text { PNL-AL0-445 }\end{array}$ & $10 \mu \mathrm{g} / \mathrm{g}$ & $\pm 20 \%$ & SPC \\
\hline $\begin{array}{l}\text { Thermal Ionization } \\
\text { Mass Spectroscopy } \\
\text { (TIMS) Plasma Mass } \\
\text { Spectroscopy } \\
\text { (ICPMS) }\end{array}$ & $\begin{array}{l}\text { U I sotopics } \\
{ }^{233} \mathrm{U},{ }^{234} \mathrm{U},{ }^{235} \mathrm{U}, \\
{ }^{236} \mathrm{U},{ }^{238} \mathrm{U},\left({ }^{236} \mathrm{Pu},\right. \\
{ }^{239} \mathrm{Pu},{ }^{240} \mathrm{Pu}, \text { and } \\
\left.{ }^{241} \mathrm{Pu}\right)\end{array}$ & $\begin{array}{l}\text { PNL-AL0-455 } \\
\text { (TIMS) } \\
\text { LA-506-101 } \\
\text { (ICPMS) }\end{array}$ & $25 \mu \mathrm{g} / \mathrm{g}$ & $\pm 20 \%$ & SPC \\
\hline \multirow[t]{10}{*}{$\overline{\text { GEA }}$} & & $\begin{array}{l}\text { LA-548-121 } \\
\text { PNL-ALO-450 }\end{array}$ & & & \\
\hline & ${ }^{134} \mathrm{Cs}$ & & $0.20 \mu \mathrm{Ci} / \mathrm{g}$ & $\pm 20 \%$ & -- \\
\hline & ${ }^{137} \mathrm{Cs}$ & & $0.015 \mu \mathrm{Ci} / \mathrm{g}$ & $\pm 20 \%$ & SPC \\
\hline & ${ }^{60} \mathrm{Co}$ & & $0.010 \mu \mathrm{Ci} / \mathrm{g}$ & $\pm 20 \%$ & SPC \\
\hline & ${ }^{249} \mathrm{Am}$ & & $15.0 \mu \mathrm{Ci} / \mathrm{g}$ & $\pm 20 \%$ & $-\infty$ \\
\hline & ${ }^{152} \mathrm{Eu}$ & & $1.5 \mu \mathrm{Ci} / \mathrm{g}$ & $\pm 20 \%$ & -- \\
\hline & ${ }^{154} \mathrm{Eu}$ & & $1.5 \mu \mathrm{Ci} / \mathrm{g}$ & $\pm 20 \%$ & -- \\
\hline & ${ }^{155} \mathrm{Eu}$ & & $2.0 \mu \mathrm{Cj} / \mathrm{g}$ & $\pm 20 \%$ & -- \\
\hline & ${ }^{212} \mathrm{Bi}$ & & $10.0 \mu \mathrm{Ci} / \mathrm{g}$ & $\pm 20 \%$ & -- \\
\hline & ${ }^{208} \mathrm{~T} 1$ & & $30.0 \mu \mathrm{Ci} / \mathrm{g}$ & $\pm 20 \%$ & -- \\
\hline
\end{tabular}

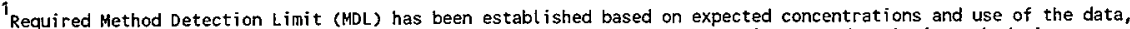
taking into account different capabilities of the laboratories for the equipment and analysis methods in use.

2 Measured sample precision determined by duplicate analyses. The Relative Percent Difference (RPD) between the duplicate analyses is within the specified bounds; e.9., $-20 \%<$ RPD $<20 \%$. RPD $=[($ result1 - result 2$) /$ mean $] * 100$.

3 Al! spike recoveries should be within $\pm 25 \%$. All method standard recoveries should be within statistical process control (SPC). A serial dilution (SD) will be used to evaluate the method accuracy for some metal analytes.

${ }^{4}$ The sample preparation procedure will provide the calculation used to determine the sludge settled density.

5 Analyze for PCB using same methods as used for $K$ East canister sludge samples or as directed in LOI/SOW. All Aroclor compounds should be identified and quantified.

6 If available from routine analysis, extraordinary measures (purchase of new equipment) not required.

${ }^{7}$ Report if data are generated as part of other requested analyses.

sp--At least one spike analysis required. 
Table 9. Analytica] Requirements for the 105-K West and East Basins Floor and Pit Sludge Samples (222-S and 325 Laboratories). (Continued)

\begin{tabular}{|c|c|c|c|c|c|}
\hline Process & Constituents & Procedure & Required $\mathrm{MDL}^{1}$ & Precision ${ }^{2}$ & Accuracy ${ }^{3}$ \\
\hline & ${ }^{125} \mathrm{Sb}$ & & $10.0 \mu \mathrm{Ci} / \mathrm{g}$ & $\pm 20 \%$ & -- \\
\hline & ${ }^{106} \mathrm{Ru} / \mathrm{Rh}$ & & $35.0 \mu \mathrm{Ci} / \mathrm{g}$ & $\pm 20 \%$ & -- \\
\hline & ${ }^{144} \mathrm{Ce} / \mathrm{Pr}$ & & $25.0 \mu \mathrm{Ci} / \mathrm{g}$ & $\pm 20 \%$ & -- \\
\hline & ${ }^{95} \mathrm{Nb}$ & & $1.0 \mu \mathrm{Ci} / \mathrm{g}$ & $\pm 20 \%$ & -- \\
\hline & ${ }^{226} \mathrm{Ra}$ & & $45.0 \mu \mathrm{Ci} / \mathrm{g}$ & $\pm 20 \%$ & -- \\
\hline Gross Alpha & Total $\alpha$ & $\begin{array}{l}\text { LA-508-101 } \\
\text { PNL-AL0-420/421 }\end{array}$ & $3.0 \mu \mathrm{Ci} / \mathrm{g}$ & $\pm 20 \%$ & $\pm 25 \% \mathrm{Sp}$ \\
\hline Gross Beta & Tota1 B & $\begin{array}{l}\text { LA-508-101 } \\
\text { PNL-AL0-430/431 }\end{array}$ & $0.50 \mu \mathrm{Ci} / \mathrm{g}$ & $\pm 20 \%$ & $\pm 25 \% \mathrm{Sp}$ \\
\hline$\overline{I C P}$ & Metals & $\begin{array}{l}\text { LA-505-161 } \\
\text { PNL-ALO-211 }\end{array}$ & & & \\
\hline & Al & & $100 \mu \mathrm{g} / \mathrm{g}$ & $\pm 20 \%$ & $\pm 10 \%$ SD \\
\hline & Cd & & $15 \mu \mathrm{g} / \mathrm{g}$ & $\pm 20 \%$ & $\pm 25 \% \mathrm{Sp}$ \\
\hline & $\mathrm{Sm}$ & & $200 \mu \mathrm{g} / \mathrm{g}$ & $\pm 20 \%$ & $\pm 25 \% \mathrm{Sp}$ \\
\hline & $B$ & & $100 \mu \mathrm{g} / \mathrm{g}$ & $\pm 20 \%$ & $\pm 25 \% \mathrm{Sp}$ \\
\hline & $\mathrm{Fe}$ & & $100 \mu \mathrm{g} / \mathrm{g}$ & $\pm 20 \%$ & $\pm 10 \%$ SD \\
\hline & $\mathrm{Ba}$ & & $100 \mu \mathrm{g} / \mathrm{g}$ & $\pm 20 \%$ & $\pm 25 \% \mathrm{Sp}$ \\
\hline & $\mathrm{Cr}$ & & $20 \mu \mathrm{g} / \mathrm{g}$ & $\pm 20 \%$ & $\pm 25 \% \mathrm{Sp}$ \\
\hline & $\mathrm{Pb}$ & & $200 \mu \mathrm{g} / \mathrm{g}$ & $\pm 20 \%$ & $\pm 25 \% \mathrm{Sp}$ \\
\hline & $\mathrm{Ag}$ & & $20 \mu \mathrm{g} / \mathrm{g}$ & $\pm 20 \%$ & $\pm 25 \% \mathrm{Sp}$ \\
\hline & $\mathrm{Be}$ & & $10 \mu \mathrm{g} / \mathrm{g}$ & $\pm 20 \%$ & $\pm 25 \% \mathrm{Sp}$ \\
\hline & $\mathrm{TI}$ & & $400 \mu \mathrm{g} / \mathrm{g}$ & $\pm 20 \%$ & $\pm 25 \% \mathrm{Sp}$ \\
\hline & $\mathrm{Zn}$ & & $20 \mu \mathrm{g} / \mathrm{g}$ & $\pm 20 \%$ & $\pm 25 \% \mathrm{Sp}$ \\
\hline & $\mathrm{Cu}$ & & $20 \mu \mathrm{g} / \mathrm{g}$ & $\pm 20 \%$ & $\pm 25 \% \mathrm{sp}$ \\
\hline & $K$ & & $1000 \mu \mathrm{g} / \mathrm{g}$ & $\pm 20 \%$ & $\pm 25 \% \mathrm{Sp}$ \\
\hline & $\mathrm{Se}$ & & $200 \mu \mathrm{g} / \mathrm{g}$ & $\pm 20 \%$ & $\pm 25 \% \mathrm{Sp}$ \\
\hline
\end{tabular}

1 Required Method Detection Limit (MDL) has been established based on expected concentrations and use of the data, taking into account different capabilities of the laboratories for the equipment and analysis methods in use.

2 Measured sample precision determined by duplicate analyses. The Relative Percent Difference (RPD) between the duplicate analyses is within the specified bounds; e.g., $-20 \%<R P D<20 \%$. RPD $=[($ result $1-$ result 2$) /$ mean] $* 100$.

3 All spike recoveries should be within $\pm 25 \%$. All method standard recoveries should be within statistical process control (SPC). A serial dilution (SD) will be used to evaluate the method accuracy for some metal analytes.

${ }^{4}$ The sample preparation procedure will provide the calculation used to determine the sludge settled density.

5 Analyze for PCB using same methods as used for K East canister sludge samples or as directed in LOI/SOW. All Aroclor compounds should be identified and quantified.

6 If available from routine analysis, extraordinary measures (purchase of new equipment) not required.

7 Report if data are generated as part of other requested analyses.

$\mathrm{Sp}-$-At least one spike analys is required. 
Table 9. Analytical Requirements for the 105-K West and East Basins Floor and Pit Sludge Samples (222-S and 325 Laboratories). (Continued)

\begin{tabular}{|c|c|c|c|c|c|}
\hline Process & Constituents & Procedure & Required $\mathrm{MDL}^{1}$ & Precision ${ }^{2}$ & Accuracy \\
\hline & $M n$ & & $20 \mu \mathrm{g} / \mathrm{g}$ & $\pm 20 \%$ & $\pm 25 \% \cdot S p$ \\
\hline & $\mathrm{Mg}$ & & $200 \mu \mathrm{g} / \mathrm{g}$ & $\pm 20 \%$ & $\pm 25 \% \quad \mathrm{Sp}$ \\
\hline & $\mathrm{Ca}$ & & $200 \mu \mathrm{g} / \mathrm{g}$ & $\pm 20 \%$ & $\pm 25 \% \mathrm{Sp}$ \\
\hline & $\mathrm{Na}$ & & $200 \mu \mathrm{g} / \mathrm{g}$ & $\pm 20 \%$ & $\pm 25 \% \mathrm{Sp}$ \\
\hline & $2 r$ & & $20 \mu \mathrm{g} / \mathrm{g}$ & $\pm 20 \%$ & $\pm 25 \% \mathrm{Sp}$ \\
\hline & $\mathrm{Ni}$ & & $40 \mu \mathrm{g} / \mathrm{g}$ & $\pm 20 \%$ & $\pm 25 \% \mathrm{Sp}$ \\
\hline & $\mathrm{P}$ & & $400 \mu \mathrm{g} / \mathrm{g}$ & $\pm 20 \%$ & $\pm 25 \% \mathrm{Sp}$ \\
\hline & $B i$ & & $200 \mu \mathrm{g} / \mathrm{g}$ & $\pm 20 \%$ & $\pm 25 \% \mathrm{Sp}$ \\
\hline 6 & $\mathrm{Hf}$ & & TBD & $\pm 20 \%$ & $\pm 25 \% \mathrm{Sp}$ \\
\hline 6 & $\mathrm{Sn}$ & & TBD & $\pm 20 \%$ & $\pm 25 \% \mathrm{Sp}$ \\
\hline & U & & $1000 \mu \mathrm{g} / \mathrm{g}$ & $\pm 20 \%$ & $\pm 25 \% \mathrm{Sp}$ \\
\hline IC & $\begin{array}{l}\text { Anions--F, } \mathrm{Cl}_{3}^{-}, \\
\mathrm{NO}_{2}^{-}, \mathrm{NO}_{3-}, \mathrm{PO}_{4}{ }^{2} \\
\mathrm{SO}_{4}, \mathrm{Br}^{-}\end{array}$ & $\begin{array}{l}\text { LA-533-105 } \\
\text { PNL-ALO-212 }\end{array}$ & $20 \mu \mathrm{g} / \mathrm{ml}$ & $\pm 20 \%$ & $\pm 25 \%$ Sp \\
\hline $\begin{array}{l}\text { Solvent Extraction } \\
\text { with Liquid } \\
\text { Scintillation } \\
\text { Counter }\end{array}$ & ${ }^{99} \mathrm{Tc}$ & LA-438-101 & $0.05 \mu \mathrm{g} / \mathrm{g}$ & $\pm 20 \%$ & SPC \\
\hline $\begin{array}{l}\text { Exothermic/ } \\
\text { Endothermic }\end{array}$ & $\begin{array}{l}\text { DSC (with air and } \\
\text { nitrogen cover } \\
\text { gas) }\end{array}$ & $\begin{array}{l}\text { LA-514-114 } \\
\text { PNL-ALO-508 }\end{array}$ & -- & $\pm 20 \%$ & SPC \\
\hline $\begin{array}{l}\text { Drained Solids } \\
\text { (TWRS) }\end{array}$ & $\begin{array}{l}\text { Percent water } \\
(T G A)\end{array}$ & $\begin{array}{l}\text { LA-560-112 } \\
\text { PNL-ALO-508 }\end{array}$ & -- & $\pm 20 \%$ & SPC \\
\hline $\begin{array}{l}\text { Hot Persulfate/ } \\
\text { Coul ometry }\end{array}$ & $\begin{array}{l}\text { TIC }\left(\mathrm{CO}_{3}{ }^{2-}\right) \text { and } \\
\text { TOC/TIC/TC }\end{array}$ & $\begin{array}{l}\text { LA-342-100 } \\
\text { PNL-AL0-381 }\end{array}$ & $40 \mu \mathrm{g} / \mathrm{g}$ & $\pm 20 \%$ & $\pm 25 \% \mathrm{Sp}$ \\
\hline $\begin{array}{l}\text { Separation and } \\
\text { Beta Counting }\end{array}$ & ${ }^{90} \mathrm{Sr}$ & $\begin{array}{l}\text { LA-220-101 } \\
\text { PNL-ALO-430/431 }\end{array}$ & $1.0 \mu \mathrm{Ci} / \mathrm{g}$ & $\pm 20 \%$ & $\pm 25 \% \mathrm{Sp}$ \\
\hline
\end{tabular}

${ }^{1}$ Required Method Detection Limit (MDL) has been established based on expected concentrations and use of the data, taking into account different capabilities of the laboratories for the equipment and analysis methods in use.

2 Measured sample precision determined by duplicate analyses. The Relative Percent Difference (RPD) between the duplicate analyses is within the specified bounds; e.g., $-20 \%<$ RPD $<20 \%$. RPD $=$ [(result1 - result 2 ) $/$ mean $] * 100$.

3 Alt spike recoveries should be within $\pm 25 \%$. All method standard recoveries should be within statistical process control (SPC). A serial dilution (SD.) will be used to evaluate the method accuracy for some metal analytes.

${ }^{4}$ The sample preparation procedure will provide the calculation used to determine the sludge settled density.

5 Analyze for PCB using same methods as used for K East canister sludge samples or as directed in LOl/SOW. All Aroclor compounds should be identified and quant ified.

6 If available from routine analysis, extraordinary measures (purchase of new equipment) not required.

$7_{\text {Report if data are generated as part of other requested analyses. }}$ 
Table 9. Analytical Requirements for the 105-K West and East Basins Floor and Pit Sludge Samples (222-S and 325 Laboratories). (Continued)

\begin{tabular}{|c|c|c|c|c|c|}
\hline Process & Constituents & Procedure & Required $\mathrm{MDL}^{1}$ & Precision ${ }^{2}$ & Accuracy ${ }^{3}$ \\
\hline $\begin{array}{l}\text { Extraction and } \\
\text { A]pha Counting }\end{array}$ & ${ }^{237} \mathrm{~Np}$ & $\begin{array}{l}\text { LA-933-141 } \\
\text { PNL-ALO-415/422 }\end{array}$ & $5 \mu \mathrm{Ci} / \mathrm{g}$ & $\pm 20 \%$ & $\pm 25 \% \mathrm{Sp}$ \\
\hline $\begin{array}{l}\text { Gravimetric } \\
\text { (before and after } \\
\text { acid digest, etc.) }\end{array}$ & $\begin{array}{l}\text { Settled and dry } \\
\text { density/volume }\end{array}$ & $\begin{array}{l}\text { Sample } \\
\text { preparation } \\
\text { procedure } \\
\text { LA-519-132 }\end{array}$ & $N / A$ & $N / A$ & $N / A$ \\
\hline $\begin{array}{l}\text { Caustic Demand } \\
\text { (optional) }\end{array}$ & $\begin{array}{l}\text { Buffering } \\
\text { capacity }\end{array}$ & LA-211-104 & $0.04 \mathrm{~mole} / \mathrm{kg}$ & $\pm 20 \%$ & SPC \\
\hline $\begin{array}{l}\text { XRD--Prior to } \\
\text { Sample Heating and } \\
\text { Acid Digestion }\end{array}$ & $\begin{array}{l}\text { U (metallic), } \\
\text { Fe hydrates, } \\
\text { Al hydrates, } \\
\text { U hydrides, } \\
\text { U oxides, and } \mathrm{Zr} \\
\text { metal }\end{array}$ & PNL-ALO-268 & $\mathrm{N} / \mathrm{A}$ & $N / A$ & $N / A$ \\
\hline $\begin{array}{l}\text { XRD--Digestate } \\
\text { Residue }\end{array}$ & $\begin{array}{l}\text { Any identifiable } \\
\text { compounds } \\
\text { (analytes) after } \\
\text { acid digest and } \\
\text { caustic fusion }\end{array}$ & PNL-ALO-268 & $\mathrm{N} / \mathrm{A}$ & $N / A$ & $\mathrm{~N} / \mathrm{A}$ \\
\hline Sett]ing Rate & $\begin{array}{l}\text { Volume settled } \\
\text { versus time }\end{array}$ & $\begin{array}{l}\text { Sample } \\
\text { preparation } \\
\text { procedure }\end{array}$ & $N / A$ & $N / A$ & $\mathrm{~N} / \mathrm{A}$ \\
\hline $\begin{array}{c}\text { Particle Size } \\
\text { 1. Anatyzer } \\
\text { 2. Sieving }\end{array}$ & $\begin{array}{l}\text { Particle size } \\
\text { (submicron to } \\
0.25 \text { in.) and } \\
\text { distribution }\end{array}$ & $\begin{array}{ll}\text { 1. } & \text { LT-519-10I } \\
\text { PNL-ALO-530 } \\
\text { 2. } \\
\text { Test } \\
\text { instruction } \\
\text { approved by } \\
\text { SNFCP }\end{array}$ & $N / A$ & $N / A$ & $N / A$ \\
\hline Particle Shape & Shape & PNL-AL0-530 & $N / A$ & $N / A$ & $N / A$ \\
\hline Viscometer & Viscosity & $\begin{array}{l}\text { LT-519-115 } \\
\text { PNL-AL0-502 }\end{array}$ & $N / A$ & $N / A$ & $N / A$ \\
\hline
\end{tabular}

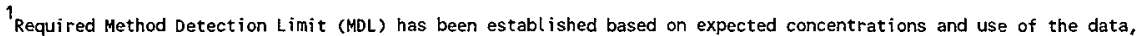
taking into account different capabilities of the laboratories for the equipment and analysis methods in use.

2 Measured sample precision determined by duplicate analyses. The Relative Percent Difference (RPD) between the duplicate analyses is within the specified bounds; e.g., $-20 \%<R P D<20 \%$. RPD $=[($ result1 - result 2$) /$ mean]*100.

3 All spike recoveries should be within $\pm 25 \%$. All method standard recoveries should be within statistical process control (SPC). A serial dilution (SD) will be used to evaluate the method accuracy for some metal analytes.

${ }^{4}$ The sample preparation procedure wilt provide the calculation used to determine the sludge settled density.

5 Analyze for PCB using same methods as used for K East canister sludge samples or as directed in LOI/sow. All Aroclor compounds should be identified and quantified.

If available from routine analysis, extraordinary measures (purchase of new equipment) not required.

7 Report if data are generated as part of other requested analyses.

Sp--At least one spike analys is required. 
Table 9. Analytical Requirements for the 105-K West and East Basins Floor and Pit Sludge Samples (222-S and 325 Laboratories). (Continued)

\begin{tabular}{|c|c|c|c|c|c|}
\hline Process & Constituents & Procedure & Required $\mathrm{MDL}^{1}$ & Precision ${ }^{2}$ & Accuracy \\
\hline Organics & SVOA--a11 TICS & $\begin{array}{l}\text { LA-523-131/406 } \\
\text { PNL-ALO-120/ } \\
344 / 345\end{array}$ & $\begin{array}{l}\text { Report TICs } \\
>10 \mathrm{ppm}\end{array}$ & $\mathrm{N} / \mathrm{A}$ & $N / A$ \\
\hline & $\begin{array}{l}\text { Polychlorinated } \\
\text { biphenyls (PCB) }\end{array}$ & $\begin{array}{l}\text { PNL-ALO-346 } \\
\text { LA-523-136 }\end{array}$ & $\begin{array}{l}1 \mathrm{ppm} \text { (solids) } \\
0.2 \mathrm{ppb} \text { (water) }\end{array}$ & $\begin{array}{l}-5 \\
--^{5}\end{array}$ & $\begin{array}{l}-5 \\
--^{5}\end{array}$ \\
\hline Zeta Potential & Zeta potential & $\begin{array}{l}\text { TWRS-95-5.6a-2, } \\
\text { Rev. } 0\end{array}$ & TBD & TBD & TBD \\
\hline pH (electrode) & $\mathrm{pH}$ & $\begin{array}{l}\text { LA-212-106 } \\
\text { PNL-ALO-225 }\end{array}$ & $0.1 \mathrm{pH}$ units & $\pm 15 \%$ & SPC \\
\hline $\begin{array}{l}\text { Gas Generation } \\
\text { Rate (optional) }\end{array}$ & $\begin{array}{l}\text { Gas volume as } \\
\text { rate of data time } \\
\text { (e.g., hours), } \\
\text { volume, and } \\
\text { temperature of } \\
\text { sludge }\end{array}$ & $\begin{array}{l}\text { Test plan } \\
\text { approved by } \\
\text { SNFCP }\end{array}$ & TBD & TBD & TBD \\
\hline $\begin{array}{l}\text { Gas Composition } \\
\text { (optional) }\end{array}$ & $\begin{array}{l}\mathrm{H}, \mathrm{He}, \mathrm{Ar}, \mathrm{N}_{2}, \\
\mathrm{Xe}, \mathrm{Kr} \text {, tritium, } \\
\text { and any other } \\
\text { significant gases }\end{array}$ & PNL-ALO-284 & TBD & TBD & TBD \\
\hline Cyanide & $\begin{array}{l}\text { LA-695-102 } \\
\text { PNL-AL0-287/289 }\end{array}$ & \begin{tabular}{|l|} 
LA-695-103 \\
PNL-AL0-287/289
\end{tabular} & $5 \mu \mathrm{g} / \mathrm{g}$ & $\pm 20 \%$ & $\pm 25 \% \mathrm{Sp}$ \\
\hline
\end{tabular}

1 Required Method Detection Limit (MDL) has been established based on expected concentrations and use of the data, taking into account different capabilities of the laboratories for the equipment and analysis methods in use.

${ }^{2}$ Measured sample precision determined by duplicate analyses. The Relative Percent Difference (RPD) between the duplicate analyses is within the specified bounds; e.g., $-20 \%<$ RPD $<20 \%$. RPD $=[$ (result $1-$ result 2$) /$ mean] $* 100$.

3 All spike recoveries should be within $\pm 25 \%$. All method standard recoveries should be within statistical process control (SPC). A serial dilution (SD) will be used to evaluate the method accuracy for some metal analytes.

4 The sample preparation procedure will provide the calculation used to determine the sludge settled density.

5 Analyze for PCB using same methods as used for $K$ East canister sludge samples or as directed in LOI/SOW. All Aroclor compounds should be jentified and quantified.

6 If available from routine analysis, extraordinary measures (purchase of new equipment) not required.

7 Report if data are generated as part of other requested analyses.

sp--At least one spike analysis required. 
Figure 6. Flow Chart of Sludge Sample Processing and Anaiyses.

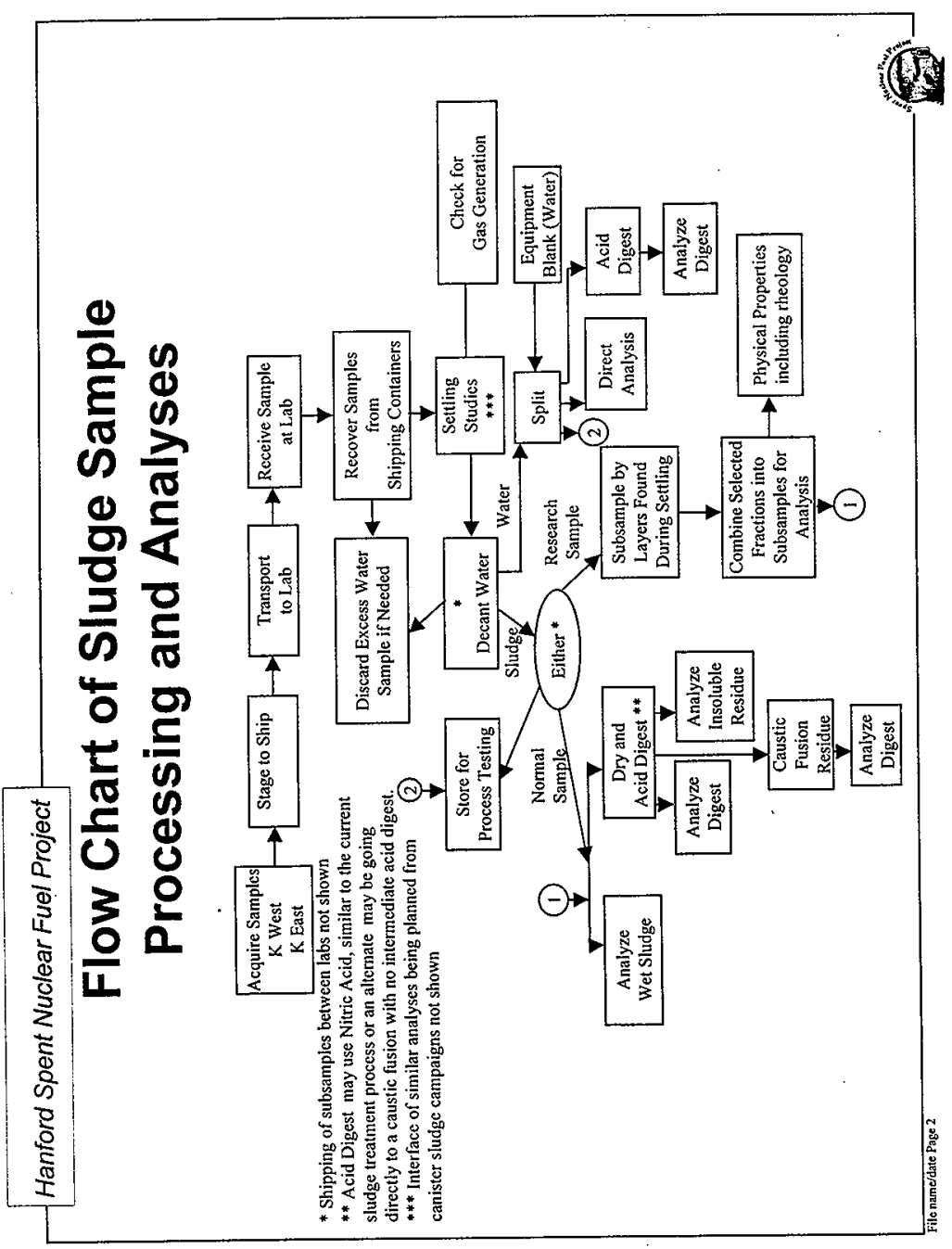


HNF-3556, Rev. 0

batch. An equipment blank from the $K$ Basin sample collection mockup may be analyzed for each set of new sampling equipment. At least one hot cell blank (if the hot cell is used) will also be analyzed. One method control standard will be run with each batch. A matrix spike will be run per matrix, where applicable, as indicated in Table 9. Also see Section 8.0 on QA requirements.

Generally analyses noted in Table 9 may be performed at either the 325 Building laboratory or the 222-S laboratory depending on sludge treatment process subproject logistics and past support in the $K$ Basins sludge characterization efforts (for consistency of data), follow-on test needs, specific laboratory capabilities, sample quantities, schedule, and contractual and HAMTC restrictions. The SOW including the detailed analyses requirements will define which laboratory will perform which analyses. All analyses will be performed consistent with doing work at the Hanford Site and as part of the Project Hanford Management Contract (PHMC).

Additional analyses of the liquid fraction of the sludge samples, beyond those noted in Figure 6, are potential options to support (1) calculation of maximum theoretical leachate concentration for RCRA heavy metals, and/or

(2) bench scale water/sludge processing tests. These will be addressed in the Sow to the laboratories if they are to be performed. It is acknowledged that due to the potential dose rate of these samples such analyses could require significant additional preparation and costs at the laboratories.

As noted earlier, additional scoping characterization analyses or combined characterization and process development tests, supporting the development and validation of treatment process may also be performed if warranted. If performed, these wi11 be consistent with the DQO and the sludge processing subproject objectives in order to utilize limited sample and maximize the use of resources (i.e., funding, laboratory waste disposal, ALAR, etc.). Such analyses will be documented in Sows to the laboratories.

Quality assurance (QA) and quality control (QC) information will conform to those required for a "fu11" data package (as discussed in the following section). The $Q A / Q C$ standards must conform to Table 9 and/or the applicable analytical procedures. The control standards, spike recoveries, precision between duplicates, hot cell blanks, and equipment blanks need to be within the specified requirements as noted in Table 9 . If the precision between duplicates or the spike recoveries exceed the appropriate criteria there are two options; (1) make one rerun to see if acceptable results are obtained (if acceptable results are not obtained, report the QC failure to SNFCP organization) or (2) report $Q C$ failure and suggested actions immediately to SNFCP Program Coordinator for evaluation.

The method detection level (MDL) as used in this document is the detection level which is expected to be achievable by the laboratory to analyze a listed constituent, yet is low enough to detect whether the constituent is present in concentrations significant to resolving data quality objectives (Makenas 1998a). 
HNF-3556, Rev. 0

Precision and accuracy requirements for laboratory analytical results specified in this document are based on an assessment of achievable laboratory capabilities, given the complex nature of the samples to be analyzed, their radioactive nature; and the consequent handling, dilution, and analysis methods prescribed. The precision and accuracy statements calculated from the $1995 \mathrm{~K}$ East Basin sludge samples were also considered in determining the requirements presented in Table 9. The DQOS for the present sampling effort (Makenas 1998a) consolidate and incorporate the various analyses performed to assure that the overall process will produce the analytical results leading to a realization of the sampling objectives. 
HNF-3556, Rev. 0

\subsection{LABORATORY REPORTING REQUIREMENTS}

The laboratories will be required to submit a final report within a period defined in the SOW from SNFCP Project Coordinator to the 1aboratories. Opportunities for parallel operations will be developed and schedules will be prepared for laboratory work which will minimize the time actually required. Samples will be processed through the laboratory with the priority required to meet the completion date given in the sow. The laboratory will be required to submit interim preliminary data reports to the SNFCP Project Coordinator as requested.

The final reports submitted to the SNFCP Project Coordinator for technical review will conform to the requirements for a "ful1" data package (e.g., similar to Silvers 1997; Miller 1997). If a laboratory uses its own set of internal sample identification numbers in the data reports, a clear cross-reference of these numbers to the original sample identifications will be provided. A narrative that summarizes the results and their quality will also be included, as we1l as the signature of the individual(s) responsible for the report. The data package will give the duplicate results, all the QC data (1aboratory method control standard results, spike recovery results, hot ce11 blank results, the equipment blank results), deviations from any of the requirements, chain of custody forms, and a narrative. Additional information on the data report content is given in Sections 3.1 and 3.2.

Data related to dose rates measured on samples to be shipped between the 325 Building and 222-S analytical laboratories, should be transmitted from the shipping laboratory to the receiving laboratory at least 5 working days prior to the actual shipment.

The laboratory performing the analyses of the PCB concentrations in the sludge samples will inform the SNFCP Project Coordinator as soon as definitive data are available. This information will also be transmitted to the laboratories, in case there are any impacts on managing waste. The information will also be provided to K. L. Pearce, NHC, for assessment of impact on sludge process treatment feed stream assumptions.

\subsection{DATA PACKAGING}

Analytical analysis results will be reviewed and processed on a priority basis by the analytical laboratories and other supporting organizations to meet the schedules provided in the SOW. 
HNF-3556, Rev. 0

This page intentionally left blank. 


\subsection{FINAL SUMMARY REPORT REQUIREMENTS}

The completed data packages from the analytical laboratories will be sent to the SNFCP Project Coordinator who will coordinate data review and final summary data report preparation. The data will be reviewed specifically against the criteria set in the DQO document (Makenas 1998a). The Project Coordinator will ensure the data and reports become a part of the permanent Project Records.

\subsection{STATISTICAL ANALYSIS REQUIREMENTS}

A statistical analysis of the data will be performed as a separate activity from the overall laboratory final data package. This analysis will be reported as part of the final summary evaluation report to be completed by the SNFCP. For each analyte, analysis of variance (ANOVA) techniques will be used to fit a statistical model to the data. This statistical model can be used to:

- Estimate the variability between samples (heterogeneity of the samples)

- Estimate the analytical variability (precision)

- Compute confidence intervais (e.g., $95 \% 90 \%$, etc.) on the mean concentration for each analyte consistent with the requirements of the $D Q 0$ and sludge process treatment subproject at the time of the report

- Compare present sludge data to past campaigns. 
HNF-3556, Rev. 0

This page intentionally left blank. 


\subsection{SAFETY PLANS}

\subsection{RADIATION/INDUSTRIAL SAFETY}

An industrial safety assessment will be performed prior to the start of these activities consistent with the requirements of each performing facility or laboratory. The requirements of HSRCM-1, Hanford Site Radiologjcal Control Manual, shall be adhered to during the performance of sampling activities.

\subsection{NUCLEAR CRITICALITY SAFETY}

A Criticality Safety Assessment will be performed in accordance with requirements of each facility or laboratory involved [e.g., K Basin Master Work Plan (MWP-95-TBD) ], prior to the start of each activity. The requirements determined by these assessments shall be adhered to during the performance of the sampling activities. 
HNF-3556, Rev. 0

This page intentionally left blank. 
HNF-3556, Rev. 0

\subsection{GENERAL ALARA PLAN}

The sampling procedure for the activities discussed in Section 2.3.1 will take into consideration exposure reduction techniques which will minimize the radiation exposure to the sampling team.

ALARA considerations will be an integrated part of the design effort for the sampling and sampling equipment to minimize personnel exposure. The application of the sampling equipment will be made under specific ALARA plans developed and applied at the K Basins during the campaign. Each laboratory will apply its own review and ALARA plan consistent with operation on the Hanford Site (e.g., the Hanford Site Radiological Control Manual, HSRCM-1). 
HNF-3556, Rev. 0

This page intentionally left blank. 
HNF-3556, Rev. 0

\subsection{QUALITY ASSURANCE AND CONTROL PLAN}

All sampling, sample handling, sample packaging/shipping, and analytical process activities will be performed in accordance with the requirements of this plan, along with the approved sampling and analysis procedures. The controls identified in this $\mathrm{plan}$, along with those contained in the program plan, have been established to assure the applicable quality assurance requirements of 10CFR830.120 and FDH QAPD (HNF-MP-599, Rev. 2), are satisfied during the performance of this activity. In addition, the analytical laboratory will perform the analyses to its internal quality assurance program plans. The 222-S laboratory wi11 follow WHC-SD-CP-QAPP-016, Qual ity Assurance Program Plan for Laboratory Analysis and Process Testing. The 325 Building 7aboratory wil1 fol1ow MCS-033, Quality Assurance P1an for Activities Conducted by the Analytical Chemistry Laboratory.

Method specific quality control and quality assurance such as calibrations and blanks are found in the anaTytical procedures noted in Table 9. Sample quality control (duplicates, spikes, and standards) are identified in Section 3.2 or in the following paragraph. If no criteria are provided in the current document, the performing laboratory shall perform to its quality assurance $\mathrm{p} T \mathrm{an}(\mathrm{s})$.

Sample groups will be assigned categories in the Sow that reflect the number of duplicates and spike analyses that should be run. The categories are:

$\frac{\text { Category }}{1}$

Duplicate analyses will be performed on al1 "first-time" characterization samples (i.e., all samples from $K$ West Basin, plus those from K East Basin containing locations KE-7, KE-8, and KE-11). There should be at least four samples receiving duplicate analyses if there is an insufficient number of samples from those indicated, the laboratory will select enough additional samples to provide a total of four. One of the samples used for duplicate analyses will be chosen by the laboratory for spike analyses. The balance of the samples will be handled as normal laboratory batches with QA as per each laboratories internal QA plan.

2 For the two "research" samples the laboratories will run duplicates on layer analyses, no spike analyses are required.

As noted previously, duplicates are repeats of all analyses after completion of settling analyses. Selection of samples within categories should optimize the use of samples with larger volumes for duplicates, allowing the maximum number of requested analyses to be performed for each category.

Care should be taken with water samples processed in conjunction with the sludge analyses (e.g., equipment blanks, etc.), processing them on a best effort basis with criteria similar to that called out in Table 9, the applicable laboratory procedures, or as called for in the final sow. 
HNF-3556, Rev. 0

This page intentionally left biank. 
HNF-3556, Rev. 0

\subsection{REFERENCES}

Alderman, C. J., 1997, Internal Memo to R. P. Omberg, "Request for Additional Laboratory Tests on Archive K East Basin Floor/Pit Sludge and Canister Sludge," CJA-97-001.

Baker, R. B., 1998a, "Revised Estimates of Sludge Volumes in K East and K West Basins," DESH-9857199, to K. L. Pearce, (included as Appendix A of this SAP), Duke Engineering \& Services Hanford, Inc., Richland, Washington.

Baker, R. B., 1998b, System Design Description for Sampling in K Basin Fuel Storage Canisters, WHC-SD-SNF-SDD-004, Rev. OA, Westinghouse Hanford Company, Richland, Washington.

Baker, R. B., 1996, Internal Memo to R. P. Omberg, "Recommended K West Basin Canisters for S1udge Sampling, "Westinghouse Hanford Company, Richland, Washington.

Baker, R. B., 1995a, Summary Status of K Basin Sludge Characterization, WHC-SD-SNF-TI-006, Rev. 0, Westinghouse Hanford Company, Rich 7 and, Washington.

Baker, R. B., 1995b, Internal Memo to T. L. Welsh, Potential Parameters Influencing Floor S7udge Volume or Composition at K East Basin, (Appendix in Welsh 1995), Westinghouse Hanford Company, Richland, Washington.

Baker, R. B., 1995c, System Design Description: Sampling Equipment for $K$ Basin Floor Sludge, WHC-SD-SNF-SDD-003, Rev. OA, Westinghouse Hanford Company, Richland, Washington.

Bechtold, D. B., 1994, Report of Laboratory Test Plan for Analysis of KE Basin Backwash Pit Samples, WHC-SD-NR-TRP-021, Rev. 0, Westinghouse Hanford Company, Rich1and, Washington.

Bechtold, D. B., 1993, Laboratory Test P7an for Analysis of KE Basin Backwash Pit Samples, WHC-SD-NR-TP-023, Rev. 1, Westinghouse Hanford Company, Richl and, Washington.

Bridges, A. E., 1996, Internal Memo to D. L. Edwards and K. J. Young, Instructions for Cleaning K Basin Canister S7udge Sample Containers, Westinghouse Hanford Company, Richland, Washington.

Delegard, C. H., et al., 1998, K Basin S7udge Materials Treatment Testing Strategy, HNF-1926, Rev. 0, Pacific Northwest Nationa] Laboratory, Richl and, Washington.

Dodd, E. N. Jr., 1995, 105-KW Sandfilter Backwash Pit S7udge Volume Characterization, WHC-SD-SNF-TI-010, Rev. 0, Westinghouse Hanford Company, Richland, Washington. 
HNF-3556, Rev. 0

\subsection{REFERENCES (Continued)}

Fink, S. D., et a1., 1998, S7udge Treatment System Project Independent Review Team Report: Process Flow Review, Numatec Hanford Corporation, Richland, Washington.

Flament, T. A., 1998a, Testing Strategy to Support the Development of $K$ Basin Sludge Treatment Process, HNF-2574, Rev. 0, Numatec Hanford Corporation, Richland, Washington.

Flament, T. A., 1998b, SNF Project S7udge Treatment System Process Flow Diagram, H-1-81170, EDT 625270, Numatec Hanford Corporation, Richland, Washington.

Fowler, K. D., 1995a, Data Quality Objectives for Waste Tank Farms Compatibility Program, WHC-SD-WM-DQ0-001, Rev. 1, Westinghouse Hanford Company, Richland, Washington.

Fowler, K. D., 1995b, Tank Farm Waste Transfer Compatibility Program, WHC-SD-WM-OCO-015, Rev. OA, Westinghouse Hanford Company, Richland, Washington.

HSRCM-1, Hanford Site Radiological Control Manual, Westinghouse, Hanford Company, Richland, Washington.

Maassen, D. P., and N. R. Roe, 1997, Floor S7udge Depths and Volume of the 105-K West Basin, HNF-SD-SNF-TI-054, Rev. 0, Duke Engineering \& Services Hanford, Inc., Richland, Washington.

Makenas, B. J., 1998a, Data Quality Objectives for Sampling of Sludge from the $K$ West and $K$ East Basin Floor and from Other Basin Areas, HNF-2033, Rev. 0, Duke Engineering \& Services Hanford, Inc., Richland, Washington.

Makenas, B. J., et a1., 1998b, Analysis of sludge from $K$ West Basin Canisters, HNF-1728, Rev. 0, Duke Engineering \& Services Hanford, Inc., Richland, Washington.

Makenas, B. J., Pearce, K. L., and Baker, R. B., 1996a, Data Quality Objectives for $K$ West Basin Canister Sludge Sampling, WHC-SD-SNF-DQ0-012, Rev. 0, Westinghouse Hanford Company, Richland, Washington.

Makenas, B. J., 1996b, Canister Choices for Sampling of Fuel and S7udge from $K$ West Basin Canisters (Second Characterization Campaign), HNF-SD-SNF-SM-006, Rev. 0, Duke Engineering and Services Hanford, Inc., Richland, Washington.

Makenas, B. J., et a1., 1996c, Analysis of Sludge from the $K$ East Basin and Wease7 Pit, WHC-SP-1182, Westinghouse Hanford Company, Richland, Washington.

Meznarich, H. K., 1998, Qua7ity Assurance Program Plan for Laboratory Ana7ysis and Process Testing, WHC-SD-CP-QAPP-016, Rev. 3A, Westinghouse Hanford Company, Richland, Washington. 
HNF-3556, Rev. 0

\subsection{REFERENCES (Continued)}

Miller, G. L., 1997, Chemical and Radiochemical Characterization of 105-K East Basin Canister S7udge, HNF-SD-WM-DP-228, Rev. OA, Rust Federal Services of Hanford, Inc., Richland, Washington.

Miller, G. L., 1996, Final Chemical and Radiochemical Analytical Report of 105-K East Basin S7udge, WHC-SD-SNF-DP-004, Rev. 1D, Westinghouse Hanford Company, Richland, Washington.

Miller, G. L., 1995, Interim Chemical and Radiochemical Analytical Report of 105-K East Basin S7udge, WHC-SD-SNF-DP-004, Rev. 0, Westinghouse Hanford Company, Richland, Washington.

Packer, M. J., 1998, K Basins S7udge Inventory Composition, HNF-SD-SNF-TI-053, Rev. 0, Duke Engineering \& Services Hanford, Inc., Richland, Washington.

Pearce, K. L., et al., 1998a, Data Quality Objectives for K Basin Conditioning System Laboratory Testing, HNF-1927, Rev. 1, Duke Engineering \& Services Hanford, Inc., Richland, Washington.

Pearce, K. L., et a1., 1998b, 105-K Basin Material Design Basis Feed Description for Spent Nuclear Fuel Project Facilities, Volume 2, Sludge, HNF-SD-SNF-TI-009, Rev. 2, Numatec Hanford Corporation, Richland, Washington.

Pitner, A. L., 1997, Visual Examinations of $K$ West Fuel Elements, HNF-SD-SNF-TI-046, Rev. O, Duke Engineering and Services Hanford, Inc., Richland, Washington.

Pitner, A. L., 1996, Test Plan for K East Visual and U7trasound Survey of Candidate Canisters for Fuel and Sludge Characterization, WHC-SD-SNF-TP-024, Rev. 0, Westinghouse Hanford Company, Richland, Washington.

PNL, 1991, Quality Assurance P7an for Activities Conducted by the Analytical Chemistry Laboratory ( $A C L$ ), MCS-033, Rev. 0, Pacific Northwest Laboratories, Richland, Washington.

Silvers, K. L., 1997, K East Basin Canister S7udge Samp7e Analysis, Pacific Northwest National Laboratory, Richland, Washington.

Silvers, K. L., 1995, K Basin S7udge Sample Analysis, Basin Floor and Weasel Pit, Pacific Northwest National Laboratory, Richland, Washington.

Trimble, D. J., and T. L. Welsh, 1997a, Cesium-137 in K West Basin Canister Water, HNF-SD-SNF-ANAL-014, Rev. 0, Duke Engineering and Services Hanford, Inc., Richland, Washington.

Trimble, D. J., Internal Memo to D. S. Takasumi, 1997b, "K West Basin Canister S7udge Inventory." 


\subsection{REFERENCES (Continued)}

Welsh, T. L., R. B. Baker, B. J. Makenas, and K. L. Pearce, 1996, Sampling and Analysis Plan for S7udge Located in Fuel Storage Canisters of the 105-K East Basin, WHC-SD-SNF-PLN-016, Rev. 0, Duke Engineering and Services Hanford, Inc., Richland, Washington.

Welsh, T. L., R. B. Baker, B. J. Makenas, and K. L. Pearce, 1995, Sampling and Analysis Plan for Floor S7udge of the 105-K East Main Basin and Weasel Pit, WHC-SD-SNF-PLN-006, Rev. 0, Westinghouse Hanford Company, Richl and, Washington.

Williams, N. H., Letter to E. D. Sellers (RL), 1996, "Sludge Disposal Plan of Execution," 9656039.

Will is, N. P., 1993, Hanford Site Waste Acceptance Criteria, WHC-EP-0063-4, Westinghouse Hanford Company, Richland, Washington. 
HNF-3556, Rev. 0

A P PENDIX A

SUMMARY LETTER (DESH-9857199) DOCUMENTING ESTIMATED VOLUMES OF SLUDGE IN K BASINS 
HNF-3556, Rev. 0

This page intentionally left blank. 
HNF-3556, Rev. 0

\section{CORRESPONDENCE DISTRIBUTION COVERSHEET}

kuthor

R. B. Baker

$376-5109$
Aobiressee

Mis. K. L. Pearce, INHC
Correspondenes lio.

DESH-9857199

Subject: REVISED ESTIMATES OF SLUDEE VOLUMES IN $K$. EAST AND $K$ WEST BASINS

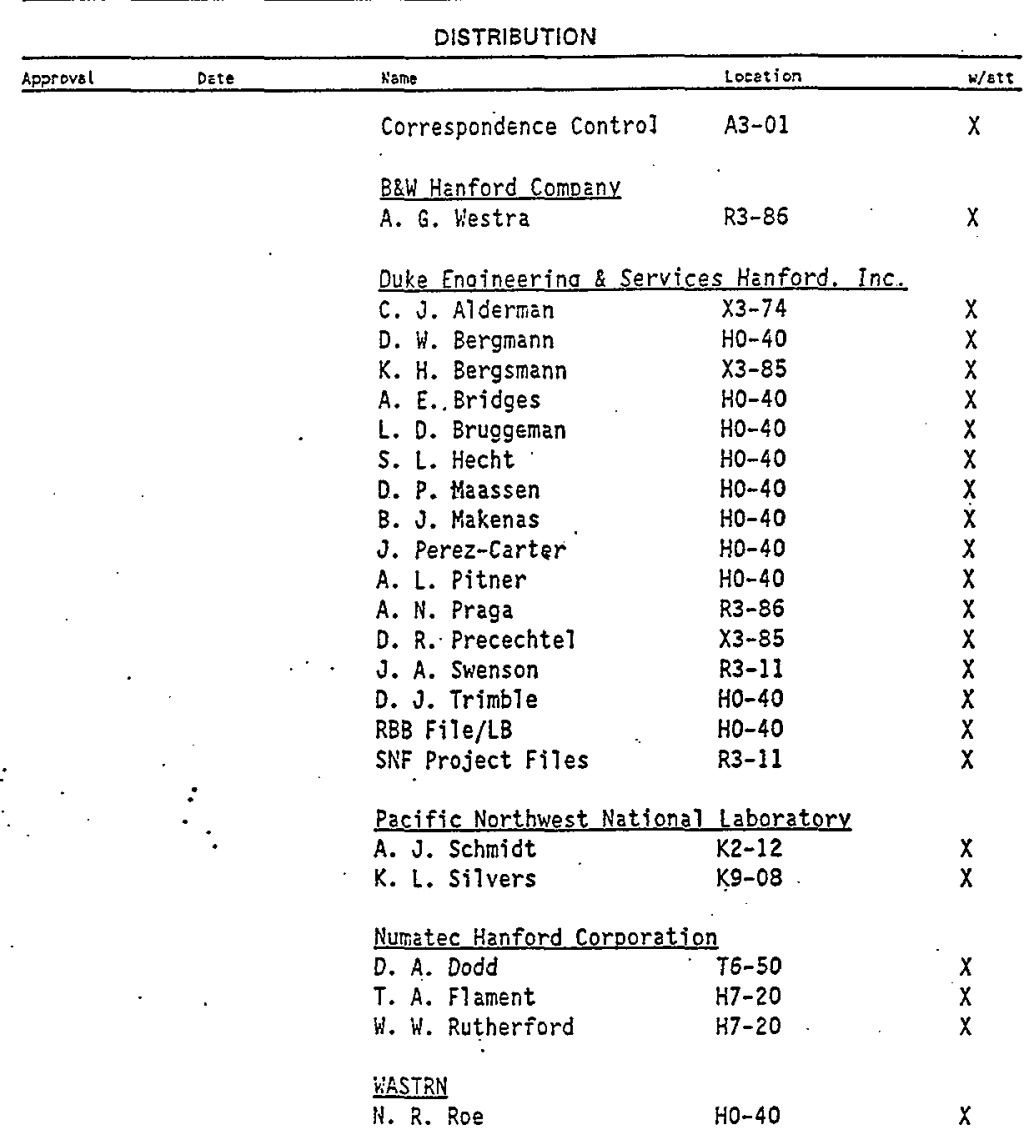


P.O. Box 350

Richlard, Wh 99352

August 28,1998

DESH-9857199

Ms. K. L. Pearce

Spent Nuclear Fuel Project, Process Design

Numatec Kanford Corporation H7-2O

Post Office Box 1300

Richland, Washington $99352-1300$

Dear Mis. Pearce:

REVISED ESTIMATES OF SLUDGE VOLUMES IN $K$ EAST AND $K$ WEST BASINS

Reference: Internal liemo, R. B. Baker to K. L. Pearce, "Current Estimates of Sludge Volumes in K East and K hiest Basins," dated Narch 19, 1997.

In March 1997, a review was made of the volume estimates of siudge from the $K$ East and $K$ West Basins (Reference). Considered were the volumes of sludge (1) on the main basin floors, (2) in remote pits, (3) in fuel storage canisters, and (4) that expected to be generated from washing the storage canisters and fuel elements prior to packaging the fuel elements in the spent Nuclear Fuel (SNF) multi-canister overpacks (MCOs).

Per your request, and with your support, we have reviewed these original estimates and their sources. Many of them still remain the best values available. There have been, however, some changes (such as additional measurements from $K$ hest Basin and improved estimates based on additional characterization data) which have resulted in revision of some of the previous sludge volume estimates. The revised sludge volume estimates and those still applicable are sumiarized herein (Attachments 1 and 2).

.Please contact me if you have questions or you need additional information.

Very truiy yours,

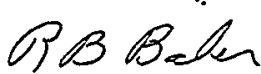

R. B. Baker, Senior Engineer SNF Characterization Project

jos

Attachments 2 . 
HNF-3556, Rev. 0

DESH-9857199

ATTACHMENT 1

Page 1 of 8

$K$ EAST AND $K$ WEST BASINS REVISED SLUDGE VOLUME ESTIMATES

R. B. Baker

August 28,1998

\subsection{SUMMARY}

The revised estimates of sludge volumes in the $K$ Basins based on this review are provided in Tables 1 and 2 . Figures 1 through 3 provide overviews of the volume fractions of sludge for both basins together and separately. As used throughout the Spent Nuclear Fuel (SNF) Project, the physical definition of sludge used herein was particulate materials in K Basins (i.e., sand, fuel, corrosion products, cladding, IXM beads, insects, etc.) with no pieces greater than those expected to pass through a screen with 0.25 inch (6350 microns) openings.

\subsection{SUMMARIES OF SLUDGE VOLUMES MADE PREVIOUSLY THAT ARE STILL VALID}

A general review was made of the previously provided $K$ Basins sludge volume estimates (Baker 1997). It was determined that the volume estimates for sludge reported in Baker (1997) remain unchanged for the following areas (the primary references these data come from is also indicated):

- K East (KE) Basin main floor (Baker 1995)

- KE Basin remote pits (Baker 1995; Makenas et al. 1996)

- KE Basin canisters (Pitner 1996)

- $\quad K$ West (KW) Basin North Loadout Pit (Baker 1995; Dodd 1995)

Attachment 2 of the current letter provides the text from Baker (1997) for reference with respect to the assumptions made for these areas. The KW Basin North Loadout Pit (or Sandfilter Backwash Pit) values had a minor error in Baker (1997), the sludge depths were incorrect, the sludge volumes quoted were correct. In addition, for consistency it is suggested you refer to the more detailed Dodd (1995) for the sludge measurement data for this pit, as well as Baker (1995).

\subsection{REVISED ESTIMATES OF SLLDGE VOLUMES AT $K$ BASINS}

\section{Fuel Wash sludoe}

Recent estimates of volumes of sludge have just been completed for the material generated during washing of canisters and fuel elements at both $\mathrm{KE}$ and $\mathrm{KH}$ Basins (Pearce and Pitner, 1998a and 1998b, respectively). These estimates replace prior fuel wash siudge estimates and are being revised based on the availability of additional data from laboratory evaluations of material from the $K$ Basins fuel element surface and subsurface examinations (Pitner 1997; Silvers 1998). Aoditionally, it vas previously assumed that 
HNF-3556, Rev. 0

DESH-9857199

ATTACHMENT 1

Page 2 of 8

fuel wash sludge was generated by metal fuel pieces being granulated (crushed) in the fuel washing machine and thus, turned into adoitional sludge. This assumption has been revised as it is now judged that the washing machine does not have the capability to significantly "granulate" the fuel pieces. However, it is expected that the washing process will cause further breakage of the elements and dislodge corroded uranium pieces, zirconium cladding, and loosely adhered material (such as coatings and internal sludge). This dislodged material is referred to as the "fuel wash sludge" and is assumed comprised of three components; pieces of coatings, fuel pieces and internal sludge (i.e., siudge originating directly from within the fuel elements). The fuel wash sludge component volume calculations are documented in Pearce and Pitner (1998a and 1998b). The calculated volumes for the KE Basin and KW Basin fuel wash sludge components are provided in Tables 1 and 2, respectively.

\section{K West Basin Canister sludoe}

Volume estimates for $\mathrm{KW}$ Basin canister sludge made previously were based on laboratory measurements of $K E$ canister sludge density and measured ${ }^{137}{ }^{1} S$ content found in the water of the closed canister barrels in KW Basin (Trimble 1997). These prior estimates were revised (Pearce and Pitner 1998b) based on additional characterization data from KW Basin fuel storage canisters (Makenas et a1. 1998). The revised volumes are provided in Table 2.

\section{K West Basin Remote Pits and Main Basin Floor}

The volume of sludge in the KW Basin remote pits and on the main basin floor provided in Baker (1997) were based on a quick general survey-of-these areas with sludge depths approximated through the full depth of water in the pool. A much better estimate is now available based on direct underwater measurements of sludge depths in the remote pits (except for the North Loadout Pit) and on the main floor of KW Basin (Maassen and Roe 1997). After these measurements were made the sludge in the South Loadout Pit was pumped to the Tech View Pit South Channel. The quantity of sludge originaliy reported located in the South Loadout Pit was therefore added to the volume of sludge reported for the Tech View Pit. The final estimates of siudge in the KW Basin remote pits and on the floor of KH Basin are provided in Table 2.

\section{$\therefore$ K East Basin and $K$ West Basin North Loadout Pits}

The depths and yolumes of sludge in the North Loadout Pits (also referred to as, Sandfilter Backwash Pits) in both $\mathrm{KE}$ and $\mathrm{KW}$ Basins are based on direct measurements made at the end of 1995 (Baker 1995; Dodd 1995). Some minor. increase in sludge depths has likely occurred because of additional backwashing of the sandfilters. It is judged (based on input from $K$ Basin staff), however, that this has had little influence on the overall. volumes (i.e., within the uncertainties noted). Therefore, the volumes of sluoge in both pits are still reported the same as in Baker (1997) with exception of the comments in Section 2.0. Additionel depth measurements are planned in the future for these pits during acquisition of sludge characterization samples. 
HNF-3556, Rev. 0

DESH-9857199

ATTACHMENT 1

Page 3 of 8

\subsection{REFERENCES}

Baker, R. B., 1995, Summary Status of $K$ Basin Sludge Characterization, WHC-SD-SNF-TI-006, Rev. 0, Westinghouse Hanford Company, Richland, Hashington.

Baker, R. B., 1997, "Current Estimates of Sludge Volumes in K East and K West Basins, "Internal Memo to K. L. Pearce, dated March 19, 1997, Duke Engineering \& Services Hanford Inc., Richland, W'ashington.

Dodd, E. N. Jr., 1995, 105-KW Sandfilter Backwash Pit Sludge Volume Characterization, WHC-SD-SNF-TI-010, Rev. 0, Hestinghouse Hanford Company, Richland Washington.

Lodwick, R. J., 1997, 105 K Hest Basin: South Loadout Pit S7udge Depth Estimation, Internal Memo to D. W. Bergmann, dated August 1, 1997, Duke Engineering \& Services Hanford, Inc., Richland, Kashington.

Maassen, D. P. and N. R. Roe, 1997, Floor Sludge Depths and Volume of the 105-K Hest Basin, HNF-SD-SNF-TI-054, Rev. 0, Duke Engineering \& Services Hanford, Inc., Richland, Washington.

Makenas, B. J., et a1., 1998, Analysis of Sludge from $K$ West Basin Canisters, HNF-1728, Rev. 0, Duke Engineering \& Services Hanford, Inc., Richland, Hashington.

Makenas, B. J., T. L. Helsh, R. B. Baker, D. R. Hansen, and G. R. Golcar, 1996, Analysis of sludge from Hanford $K$ East Basin Floor and Weasel Pit, WHC-SP-1182, Rev. 0, Westinghouse Hanford Company, Richland, Washington.

Pearce, K. L., and A. L. Pitner, 1998a, K East Basin S7udge Volume Estimates for Integrated Water Treatment System, HNF-3165, Rev. 1, Duke Engineering \& Services Hanford Inc., Richland, Washington.

Pearce, K. L., and A. L. Pitner, 1998b, K West Basin Sludge Volume Estimates for Integrated Water Treatment System, HNF-3165, Rev. 1, Duke Engineering \& Services Hanford Inc., Richland, Washington.

Pjtrier, A. L.: 1997, K Basin Fuel Subsurface Examinations and Surface Coating Sampling, HNF-SD-SNF-TI-060, Rev. O, Duke Engineering \& Services Hanford Inc., Richland, Washington.

Pitner, A. L., 1996, K East Canister Sludge Survey, WHC-SD-SNF-TI-034, ReV. 0, Westinghouse Hanford Company, Richland, Washington.

Silvers", K. L.; 1998, "K Basin Fuel Subsurface Sludge and Coating Analysis," Letter PNNL 28964-02 to R. P. Omberg (DESH), Pacific Northwest National Laboratory, Richland, Washington.

Trimble, D. J.; 1997, "K hest Basin Sludge Volume Inventory," Internal. Memo to D. S. Takasumi, dated January 26, 1997, Duke Engineering \& Services Hanford, Inc., Richland, Washington. 
HNF-3556, Rev. 0

DESH-9857199

ATTACHMENT I

Page 4 of 8

Table 1. Estimates of Sluoge Volumes for K East Basin Floor, Pits, and Fuel Wash Components.

\begin{tabular}{|c|c|c|c|c|c|c|c|c|}
\hline \multirow[b]{2}{*}{ Location or Source } & \multirow{2}{*}{$\begin{array}{c}\text { Si udge } \\
\text { Average } \\
\text { Depth } \\
\text { (in.) }\end{array}$} & \multirow[b]{2}{*}{$\begin{array}{l}\text { Area } \\
\left(f t^{2}\right)\end{array}$} & \multicolumn{2}{|c|}{ Sludge Volume } & \multirow{2}{*}{$\begin{array}{c}\text { Positive } \\
\text { Percent } \\
\text { Uncertainty }\end{array}$} & \multicolumn{2}{|c|}{$\begin{array}{l}\text { Upper Bound } \\
\text { Sludge Volume }\end{array}$} & \multirow[b]{2}{*}{ Reference } \\
\hline & & & $\mathrm{ft}^{3}$ & $\mathrm{~m}^{3}$ & & $\mathrm{ft}^{3}$ & $\mathrm{~m}^{3}$ & \\
\hline $\begin{array}{l}\text { Tech View-North } \\
\text { Channel }\end{array}$ & 1.0 & 49.4 & 4.0 & 0.1 & 50 & 6.0 & 0.2 & Baker (1995) \\
\hline $\begin{array}{l}\text { Tech View-South } \\
\text { Channe? }\end{array}$ & 0.2 & 49.4 & 0.9 & 0.0 & 50 & 1.3 & 0.0 & Baker (1995) \\
\hline Tech View Pit & 0.8 & 141.5 & 10.4 & 0.3 & 50 & 15.6 & 0.4 & Baker (1995) \\
\hline Heasel Pit Channel & 12.0 & 53.8 & 53.8 & 1.5 & 20 & 64.5 & 1.8 & $\begin{array}{r}\text { Baker }(1995) \\
\text { Makenas }(1996) \\
\end{array}$ \\
\hline Weasel Pit. & 32.3 & 112.3 & 302.5 & 8.6 & 20 & 362.9 & 10.3 & $\begin{array}{r}\text { Baker }(1995) \\
\text { Makenas (1996) } \\
\end{array}$ \\
\hline North Loadout Pit & 33.0 & 66.5 & 183.0 & 5.2 & 20 & 219.6 & 6.2 & Baker (1995) \\
\hline North Loadout Channe? & 20.0 & 23.2 & 38.6 & 1.1 & 20 & 46.4 & 1.3 & Baker (1995) \\
\hline South Loadout Pit & 0.0 & 64.6 & 0.0 & 0.0 & of & 0.0 & 0.0 & Baker (1997) \\
\hline South Lodotout ChanneT & 0.0 & 23.0 & 0.0 & 0.0 & of & 0.0 & 0.0 & Baker (1997) \\
\hline Dumny Elevator pit & 6.0 & 97.0 & 48.5 & 1.4 & 50 & 72.8 & 2.1 & Baker (1995) \\
\hline Discharge Chute. & 0.0 & 316.5 & 0.0 & 0.0 & 0 & 0.0 & 0.0 & Baker (1995) \\
\hline $\begin{array}{l}\text { Main Basin Floor } \\
\text { (Open) }\end{array}$ & 1.9 & $4848.4 *$ & 760.4 & 21.5 & 20 & 912.5 & 25.8 & Baker (1995) \\
\hline Canisters--Empty & & & 13.8 & 0.4 & 20 & 16.6 & 0.5 & Baker (1995) \\
\hline Canisters--Fueled & & & 106.1 & 3.0 & 147 & 261.4 & 7.4 & Pitner (1996) \\
\hline Subtotais & & & 1522.0 & 43.1 & & 1979.6 & 56.0 & \\
\hline $\begin{array}{l}\text { Fue] Wash Components: } \\
\text { Fuel Pieces } \\
\text { Coating } \\
\text { Internal sluoge }\end{array}$ & $\begin{array}{l}\text { NA } \\
\text { NA } \\
\text { NA } \\
\end{array}$ & $\begin{array}{l}\text { NA } \\
\text { NA } \\
\text { NA } \\
\end{array}$ & \begin{tabular}{r|}
5.3 \\
2.2 \\
18.3 \\
\end{tabular} & $\begin{array}{l}0.149 \\
0.061 \\
0.518 \\
\end{array}$ & $\begin{array}{l}\text { NA } \\
\text { NA } \\
\text { NA } \\
\end{array}$ & $\begin{array}{r}13.2 \\
3.1 \\
45.7 \\
\end{array}$ & $\begin{array}{l}0.373 \\
0.092 \\
1.294 \\
\end{array}$ & Pearce (1998a) \\
\hline Grand Total & & & 1547.8 & 43.8 & & 2041.6 & 57.8 & \\
\hline
\end{tabular}

*Open area around canisters set on fioor. 
HNF-3556, Rev. 0

DESH-9857199

ATTACHHENT 1

Page 5 of 8

Table 2. Estimates of siudge Volumes for $K$ hest Basin Floor, Pits, and Fuel Wash Components.

\begin{tabular}{|c|c|c|c|c|c|c|c|c|}
\hline \multirow[b]{2}{*}{ Location or Source } & \multirow{2}{*}{$\begin{array}{l}\text { Sludge } \\
\text { Average } \\
\text { Depth } \\
\text { (in.) }\end{array}$} & \multirow[b]{2}{*}{$\begin{array}{l}\text { Area } \\
\left(f t^{2}\right)\end{array}$} & \multicolumn{2}{|c|}{ Sludge Volume } & \multirow{2}{*}{$\begin{array}{c}\text { Positive } \\
\text { Percent } \\
\text { Uncertainty }\end{array}$} & \multicolumn{2}{|c|}{$\begin{array}{c}\text { Upper Bound } \\
\text { sludge Volume } \\
\end{array}$} & \multirow[b]{2}{*}{ Reference } \\
\hline & & & $\mathrm{ft}^{3}$ & $m^{3}$ & & $\mathrm{ft}^{3}$ & $m^{3}$ & \\
\hline $\begin{array}{l}\text { Tech View-North } \\
\text { Channel }\end{array}$ & 0.066 & 49.35 & 0.27 & 0.008 & $417 * * * *$ & 1.13 & 0.032 & Maassen (1997) \\
\hline $\begin{array}{l}\text { Tech View-South } \\
\text { Channe } * *\end{array}$ & 0.319 & 49.35 & 1.27 & 0.035 & Combined** & 3.76 & 0.107 & Maassen (1997) \\
\hline Tech View Pit & 0.056 & 141.50 & 0.78 & 0.022 & 417 & 3.24 & 0.092 & Maassen (1997) \\
\hline Weasel Pit Channel & 0.066 & 50.67 & 0.282 & 0.008 & 379 & 1.07 & 0.0302 & Maassen (1997) \\
\hline Heasel Pit & 0.066 & 116.45 & 0.647 & 0.018 & 379 & 2.45 & 0.0594 & Maassen (1997) \\
\hline North Loadout Pit & 20.7 & 65.2 & 112.3 & 3.18 & 20 & 134.8 & 3.82 & Dodd (1995) \\
\hline North Loadout Channel & 8.8 & 22.7 & 16.2 & 0.46 & 20 & 19.4 & 0.550 & Dodd (1995) \\
\hline South Loadout Pit** & 0.0 & 65.00 & $0.0 * *$ & $0: 0$ & NA & 0.0 & 0.0 & Maassen (1997) \\
\hline $\begin{array}{l}\text { South Loadout } \\
\text { Channe?** }\end{array}$ & 0.0 & 22.30 & $0.0 * *$ & 0.0 & NA & 0.0 & 0.0 & Maassen (1997) \\
\hline Dumny Elevator Pit & 0.16 & 97.10 & 1.31 & 0.0371 & 385 & 5.05 & 0.143 & Maassen (1997) \\
\hline Discharge Chute & 0.052 & 526.30 & 2.28 & 0.0647 & 432 & 9.88 & 0.280 & Maassen (1997) \\
\hline $\begin{array}{l}\text { Main Basin Fioor } \\
\text { (Open) }\end{array}$ & 0.064 & $5479.2^{*}$ & 29.0 & 0.822 & 229 & 66.3 & 1.88 & Maassen (1997) \\
\hline Canisters--Fueled & NA & NA & 35.7 & 1.01 & 77 & 55.8 & 1.58 & Pearce (1998a) \\
\hline Subtotals & - & & 200 & 5.67 & & 303 & 8.58 & $\ldots$ \\
\hline $\begin{array}{l}\text { Fuel Wash Components: } \\
\text { Fuel Pieces } \\
\text { Coating } \\
\text { Internal Sludge } \\
\end{array}$ & $\begin{array}{l}N A \\
N A \\
N A \\
\end{array}$ & $\begin{array}{l}\text { NA } \\
\text { NA } \\
\text { NA } \\
\end{array}$ & $\begin{array}{r}5.26 \\
14.3 \\
18.3 \\
\end{array}$ & $\begin{array}{l}0.149 \\
0.406 \\
0.518 \\
\end{array}$ & $\begin{array}{l}150 \\
150 \\
150 \\
\end{array}$ & $\begin{array}{l}13.2 \\
21.5 \\
45.7 \\
\end{array}$ & $\begin{array}{l}0.373 \\
0.613 \\
1.294 \\
\end{array}$ & Pearce (1998a) \\
\hline Grand Total & ${ }^{\circ}$ & & 238 & 6.74 & & 383 & 20.9 & \\
\hline
\end{tabular}

* Open area around canisters set on floor.

**The sludge measured in Maassen (1997) in the South Loadout Pit was transferred to the Tech View Pit South Channel in September 1997 (Maassen 1997; Lodwick 1997). The volume of sludge measured in Maassen (1997) in South Loadout Pit (1.003 $\left.\mathrm{ft}^{3}, 0.0263 \mathrm{~m}^{3}\right)$ has been added to the Tech View Pit South Channel $\left(0.271 \mathrm{ft}^{3}, 0.00766 \mathrm{~m}^{3}\right)$ in this table. The uncertainties used were from Massen (1997) for Tech View-South Channel $417 \%$, and for the South Loadout Pit sludge volume $263 \%$.

***Uncertainties taken from Maassen (1997) were based on upper 1 imits of the $95 \%$ confidence interval including random variabilities and systematic measurement variability. 
HNF-3556, Rev. 0

Figure 1. Comparison of Sludge Volume Fractions Versus Locations or Sources at K Basins.

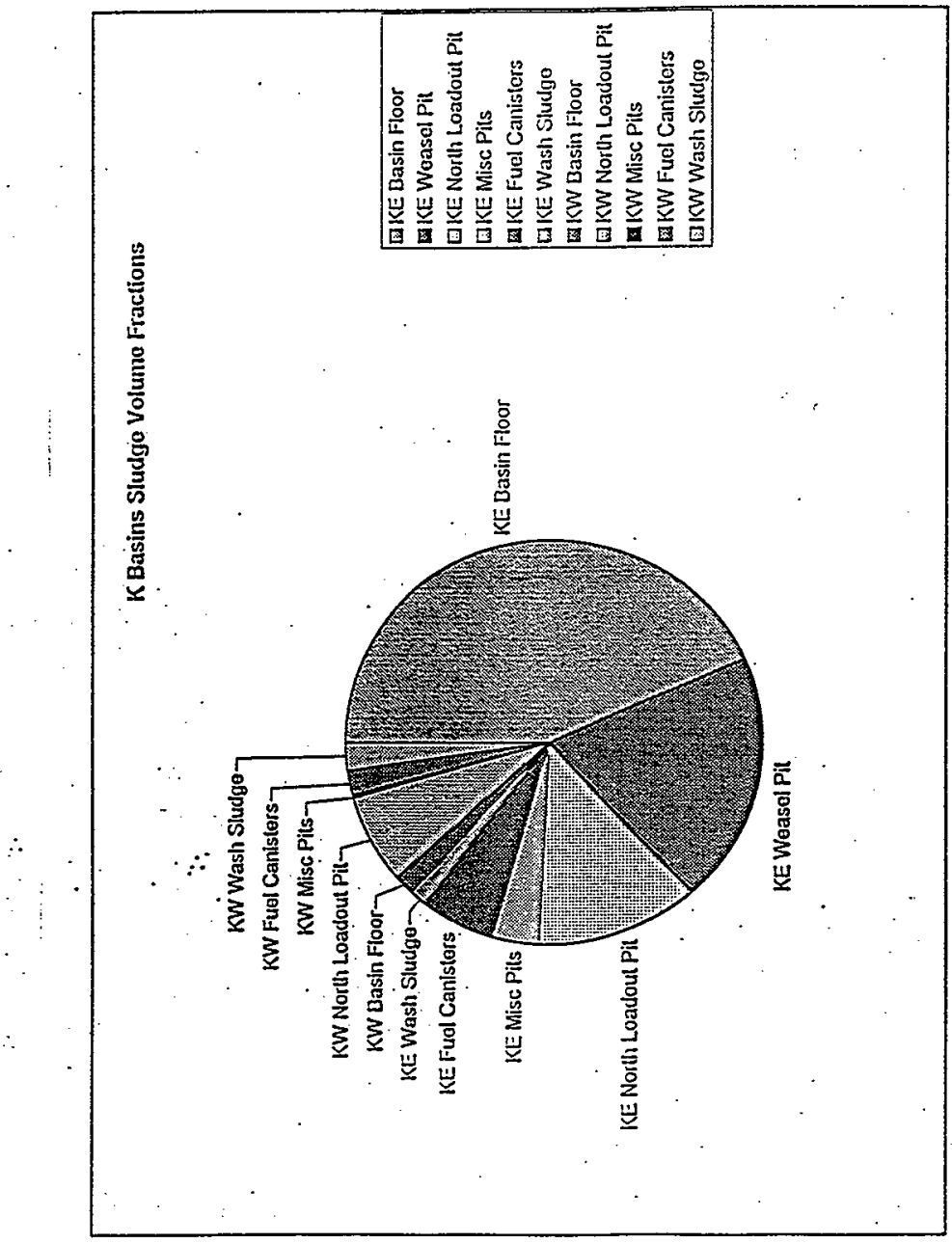


Figure 2. Comparison of STudge Volume Fractions Versus Locations or Sources at $K$ East Basin.

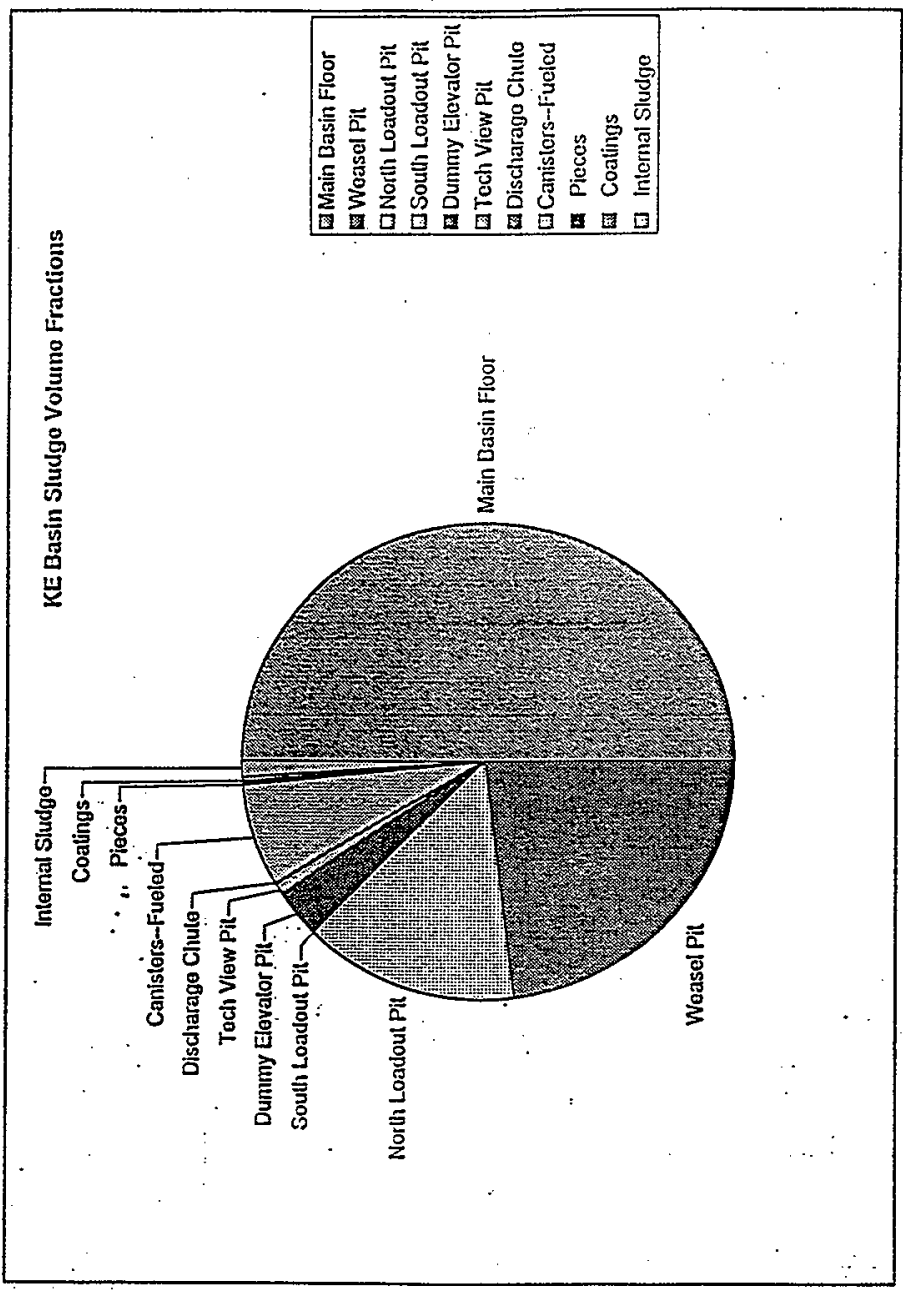


Figure 3. Comparison of Sludge Volume Fractions Versus Locations or Sources at $K$ West Basin
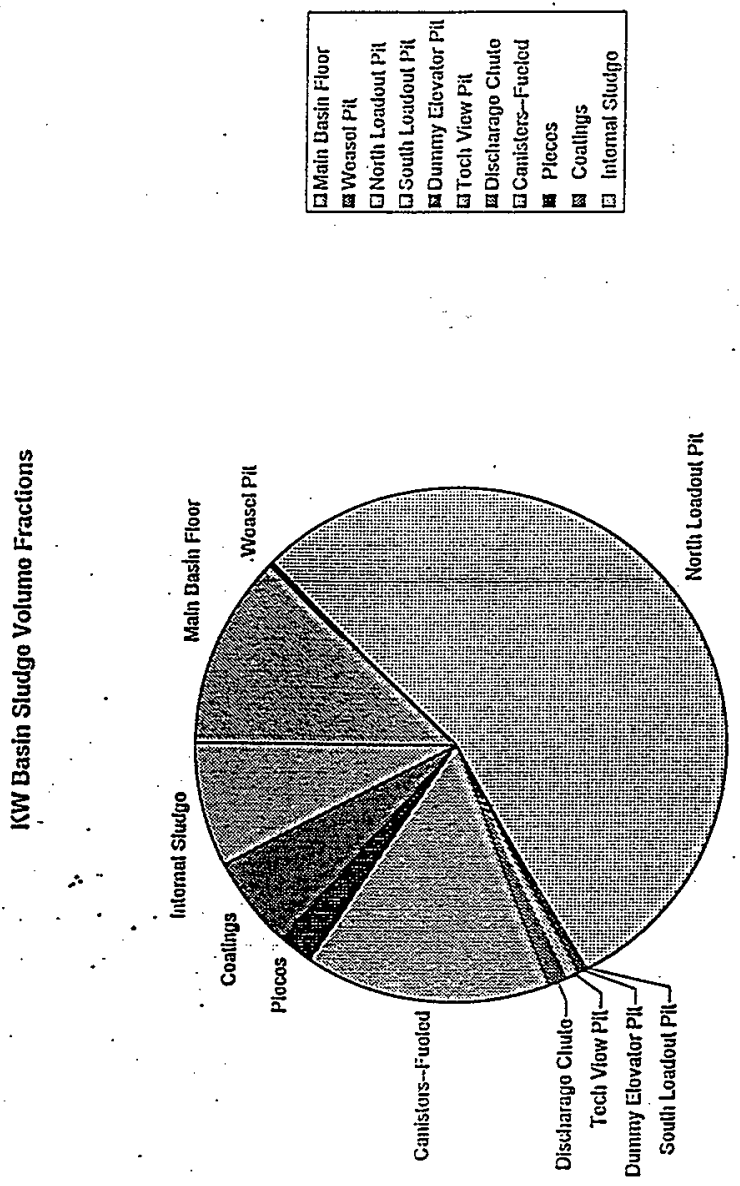
HNF-3556, Rev, 0

DESH-9857199

\section{ATTACHMENT 2}

Background Information Text from Reference Baker 1997

Consisting of 5 pages, including cover page 
From: Spent Ruclear Fuel Evaluations

Phone: 376-5109 H0-40.

Date: . March 19, 1997

SUbjeCt: CURRENT ESTIKATES OF SLUDGE VOLUMES IN $K$ EAST AND $K$ K'EST ERSINS

To:

K. L. Pearce

R3-11

cc: C. J. Aldermen

$\times 3-85$

D. H. Eergnicm

$R 3-85$

K. H: Bergsnan

$\times 3-85$

S. 1. Hecht

P. G. LEROY

B. J. Mekenes

HO- 40

R3-15

R. P. Onberg

$\mathrm{HO}-40$

$150-40$

H. J. Packer

A. L. Pitner

A. N. Praga

D. R. Precechtel

D. S. Takasumí

D. J. Trimble

RBB Fite/L3 $\times 3-85$

$\mathrm{HO}-4 \mathrm{O}$

$83-85$

$\times 3-85$

$\times 3-85$

Ho- 40 .

HO- 40

References: (1) Internal kemo, A. L. Pitner to D. S. Tekesuni, "K k'est Essin Sludige Voluhe Estimates for Integrated Wieter Treatment Systein," dated jeriuary 29 , 1E07. [Also provided in DESH EDT. 020777 dated Februery is97.]

(2) Internal Hemo, D. J. Trimble to D. S. Takasumi, "K H'est Basin siudge Volume Inventory, "dated January 26, I997.

(3) D. J. Trimbie, Cesium-137 ir K Kest Basin Cinister hater, HNF-SD-SNF-AKAL-014, Rev. 0, dated. Jeñuary 24, 1997.

(4) Internal Memo, A. L. Pitner to D. S. Takasumi, "K East Easin Sludge VoTume Estinates for Integraied kater Treatment. System," dated January 23,1097 . [Also provided in DESH EOT 620776 dated February 1997.1.

(5) A. L. Pitner, $K$ Ezst Canister sludge Survey, WHC-SD-SNF-TI-034, REV. 0, dated August $28,1295$.

(6) 3. J. Vekenas, et al., Analysis of sludge from Hanferd $K$ East Basin Floor and heasel pit, hHC-Sp-1182, dated April 1905.

(7) S. M. Short and H. M. Beary, Spent Nuelear Fuel Project - Technicz] Detzbook, SHAC-SD-SNF-TI-015, Rev. 0; dated August II, 1905 (ECN 191395 February 1986).

(8) R. B. Baker, Sumuery Stztus of K Basin spudge Characterization, WHC-SD-SNF-TI-005, Rev. 0, dated Jenuary- i205. 
HNF-3556, Rev. 0

K. L. Park

Page 2

Kierch 19, 1997

Per your request, a revieh wes iade of the current estimetes for volumes of sludge in the $K$ East sasin and $K$ hiest Basin. Considered hies the sludge on the main basin floor, in remote pits, in fuel canisters, and the poteritial for generation of siudge from weshing storage canisters/fuel prior to the fuel being packaged in multi-canister overpacks (MCOS): Attachments I ind 2 provide a sumaticy of these results.

Pest sunicries of slucice Volunites.

An original sumiary of sludge volunes in the 3asins kies provided in Reference 8. These were bised frimerily on neasurements of sludge depths made at the $K$ East and $K$ liest Besins just prior to the report being issusd (j.e., 1984). These slugige volunses, with uncertainty estimetes, here later used both in the spent huclear Fuel (SNF) project feed document ind the SNF Project Detibook, Reference 7. In many ceses these estinctes remein the best values availeble. Hovever, there heve been edditional measurements, improved estimates, and chenges afiecting some of these sluoge estimetes. For these instances the inproved values should be used and these are described in the iolTowing sections and attachnents.

Because of recent questions, it is re-emphisized here that the estinates of sludgetvolumes made in Reference 3 for the floor of the $K$ East main basin account for the fact that the fuel storage canisters sit directiy on the basin-floor, with the "floor sludge buift-up around them. Any sludge under the casisters is assuned insignificant or accounted for in the uncertainty of the. sludge voiumes projected. as residing in the canisters themselves.

\section{Revised Estimates of siudoe Voiumes at $K$ Besins}

Revised estimates of voiumes of sluoge in the fueled canisters in $K$ East Basin were made based on uitrasound measurements of siudge depths made in a set of selected fuel canisters in 1955, Reference 5. These represent a much betier estimate of this sluoge volume than that provided in Reference 8, because there is accurate direct data as a basis rather than the secondary observations used in Reference 8 . Attachiment 1 provides these revised - values. Note the mienitude of the volumes provided in these revised. estimates ate similar to those provioed in the original estimates of Reference 8 vithin the bounds: identjfied (e.g., Reference 8: total volune in fueled canisters bas about $7.5 \mathrm{~m}^{3}$ with a bounding estimate of $12.7 \mathrm{~m}^{3}$, and in Reference. 5: total volune: is $3.0 \mathrm{~m}^{3}$ bounding estimate of $7.4 \mathrm{~m}^{3}$ ).

Keasurements of sludge volume: in the fueled (sealeo) canisters in K Yest Besin. here al so ittempted using uitrasound equipment to meke depth measurements of the siudge. However, these ine surements were found to be inconsistent, es opposed to the valid measurentents resulting from the misesurenents in $K$ Eest Easin storege cenisters. The probiem with the epplication in K. Hest easin canisters kies probably caused by (1) less siudge being fresent and (2) complicetjons arjsing from pieces of the material used 
K. L. Park

Page 3

Nierch 19; 1997

to seal the canister lids falling between the fuel elements during the process of removing the cenister lids, see Reference 2. Given this, it wis judgad a better estizate of sludge volume hes possible, from measured cesiun concentrations in the water simples analyzed from- a selected set of-sealed canister barrels in $K$ hest Basin. This epproach is fully described in Reference 2, and the resulting volunes given in sttechnent 2 of the current meno.

The volume of siudge indicated in peierence 8 as contained in the lieasel pit at $K$ East Basin, has based on an inference of sludge depth measured from the shidow of sludge observed on the screen separating the heasel pit from the main basin. A much better estinite hias leter nade available based on measurenents mide in August and september 1955. These are discussed in Reference 5 , which concluded en integrated sluoge volume for the pit wis $7.4 \mathrm{~m}^{3}\left(264 \mathrm{it}^{2}\right)$. Since these measurements $\mathrm{h}^{2} \mathrm{re}$ made in 1995 at least two activities have added siudge to this pit. First, the south Loadout Pit ties cleaned and this sluce puiped to the keasel Pit. SEcond, en erea of the Center Eay of the $K$ East Eesin h'es cleaned of siudge, to support processing and cleaning empty canisters, again the siuege has pumped to the hiessel pit. Estimates of the sluege woved to the heasel pit were made based on the sludge estitiated in these ereas from Reference 8 data. These quantities Were then added to the volune of sludge estimated from measurements micose in September 1995 (Refsersice 5) for the Heasel Pit. For the South Locdout Pit a volume of $3.5 \mathrm{~m}^{3}$. Wes essuned. to have been moved; and for the cleaned. portion of the Center Bey the estimate of the associated yolume of siudge tas $0.1 \mathrm{~m}^{3}$. The later volume was subtracted from the main basin floor. value. The final estimates of sludge in the $K$ East Basin heasel pit and on the main basin floor are shorn in Attachiment 1.

A quick survey was made of the $K$ kest Basin remote pits and ma in basin floor as a result of your request. From this the estimates of sluoge depths were made that are shown in fttachnent 2. Direct physical measurement of siuoge depths on the $K$ West main basin floor and in the pits (except the North Loadout Pit) is planned to be completed by the Spent Nuciear Fuel Evaluations group. Within the next 2 months.

$\therefore$ The depths and volumes of siudge in the North Loadout Pits (i.e., Sandfilter Eack'ash Pits) in both $K$ East and $K$ Viest Basins are based on direct measurements mide it the end of 1985 , Reference 8 . Some minor increase in sluoge depths has no doutt occurred due to further backwashing of the sandifiters: It is assumed here this has had ijttle influence on the volumes (i.e., within the uncertainties noted). This wili be verified in the next year when semples, are taken from. these pits for charicterization.

similar to the North Loedout Pits, there has likely been some incresse in sludge volune on the K East wain basin floor since 1095 when depth measurements kere measurej. Here again this is assuned to be within the uncertainties indicated. 
HNF-3556, Rev. 0

K. L. Park

Pege 4

Mẹrch 19, 1997

To provide a comprehensive set of sluoge volumes, estimetes are also included in Attechant I for the future kashing of fuel end cenisters. at the $K$ East Basin; these estimates were taken from Reiterence 4. K K'est Bas in was aiso reviewed to meke a similer estimate for fuel w'ashing, Reierence 1. Here it was estimeted that at this time a value similar to the K East issin value should be used. This is reflected in Attechment 2 .

Please contact the if you have questions.

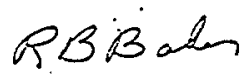

R. B. Baker, Fellow Engineer

spent kuclear Fuel Evaluations

sinn

Attachments 2

PEER REYIEH:

Q.Z. Plam

Date: $\quad 3 / 19 / 97$

Spent huclear fuel Evaluations 
HNF-3556, Rev. 0

This page intentionally left blank. 
HNF-3556, Rev. 0

A P PENDIX B

SLUDGE DEPTH ESTIMATES AND SAMPLE LOCATIONS DETAIL FOR $K$ WEST AND $K$ EAST BASINS 
HNF-3556, Rev. 0

This page intentionally left blank. 
Figure BI. Floor Sludge Depth (in inches) at Locations Measured in 1997 at K West Basin (Maassen 1997). (Prior to S7udge Being Pumped from South Loadout Pit to Tech View South Transfer Channel.)

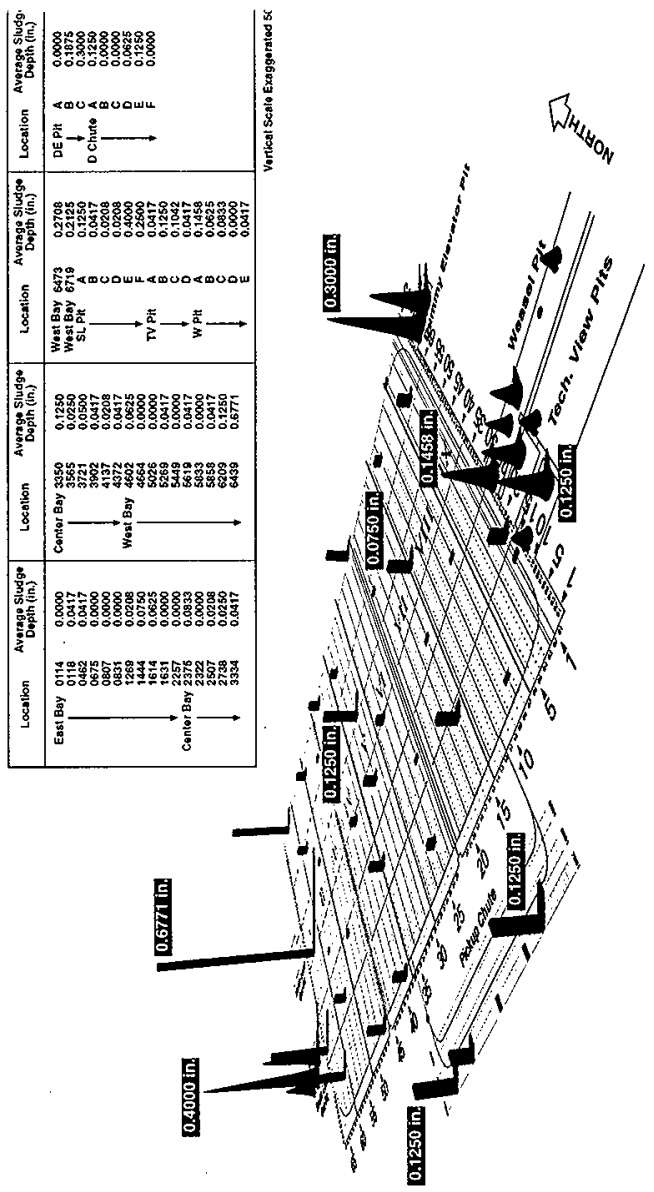


HNF-3556, Rev. 0

Figure B2. K West Basin North Loadout Pit Sample Locations.

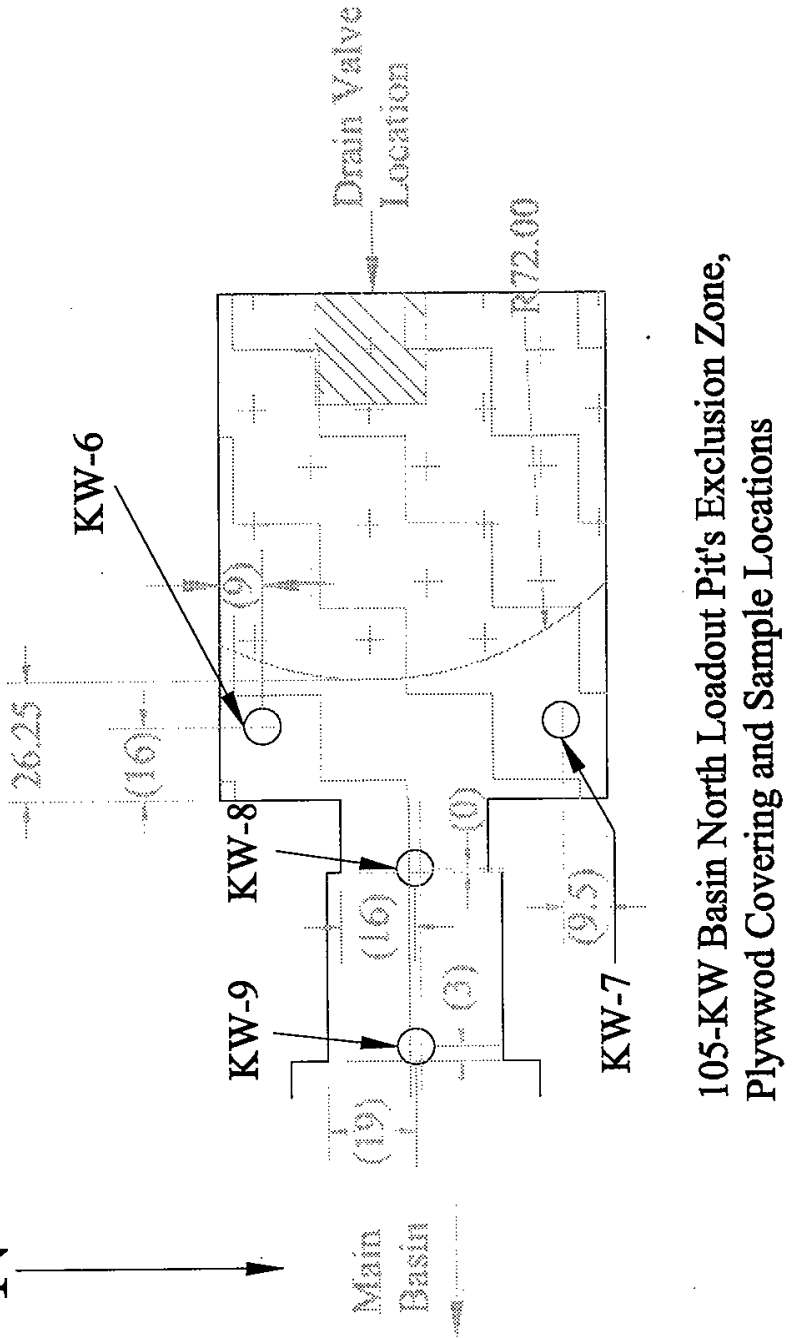


Figure B3. Surface Fit of S7udge Depth Data in $K$ West Basin North Loadout (Sandfilter Backwash) Pit in 1995.

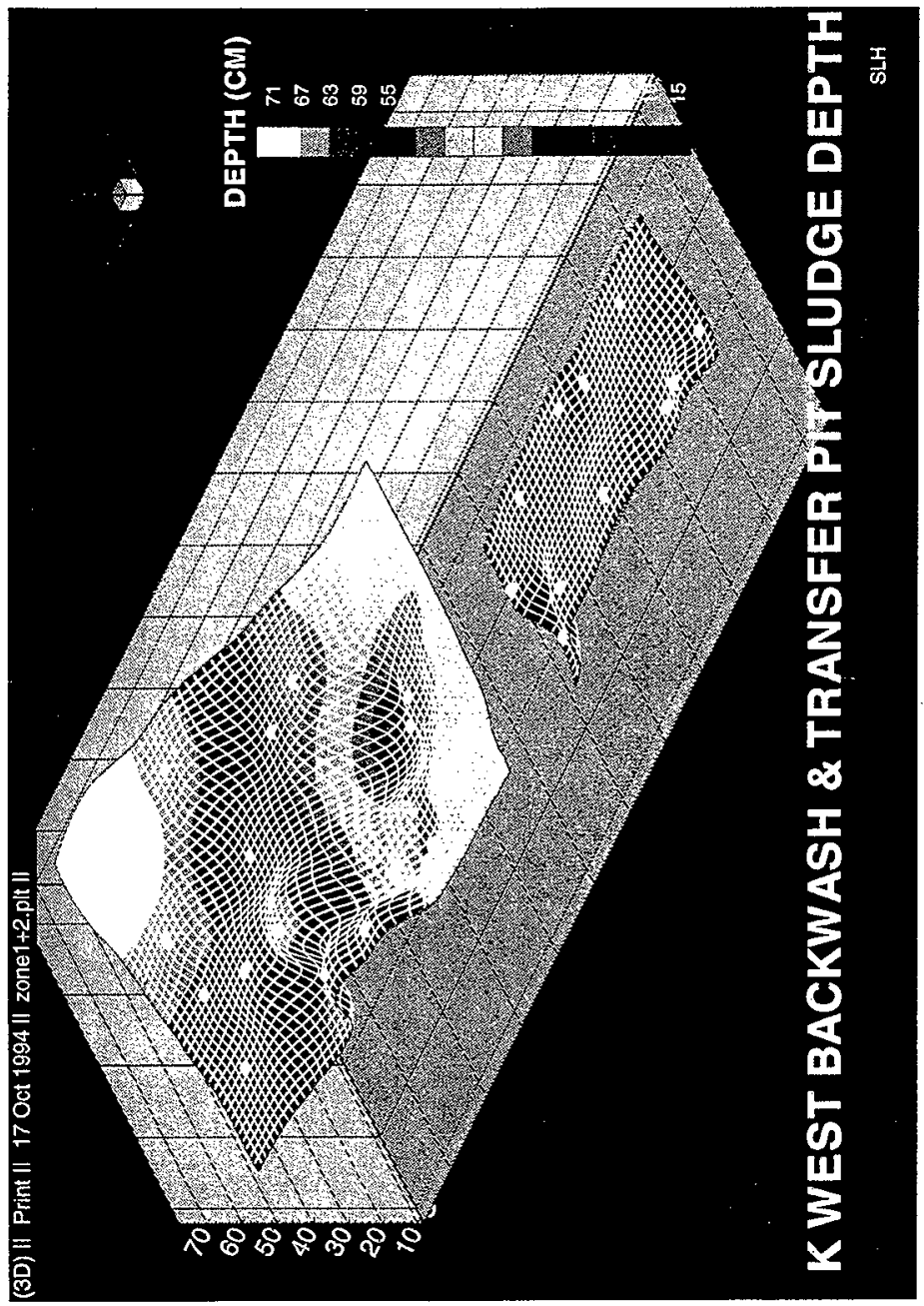


HNF-3556, Rev. 0

Figure B4. K West Basin Weasel Pit and Tech View Pit Sample Locations.

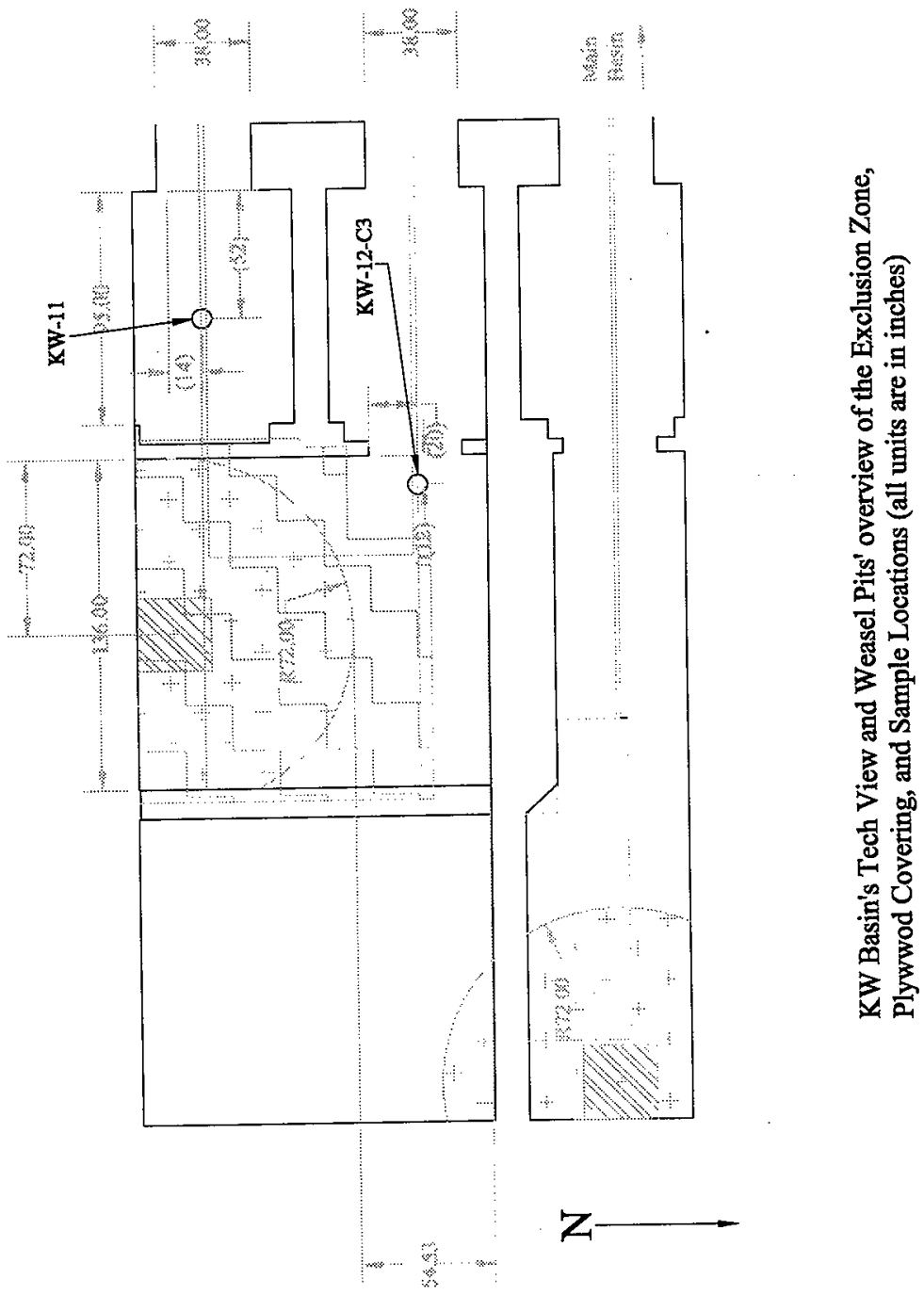


Figure B5. K West Basin Dummy Elevator Pit Sample Locations.

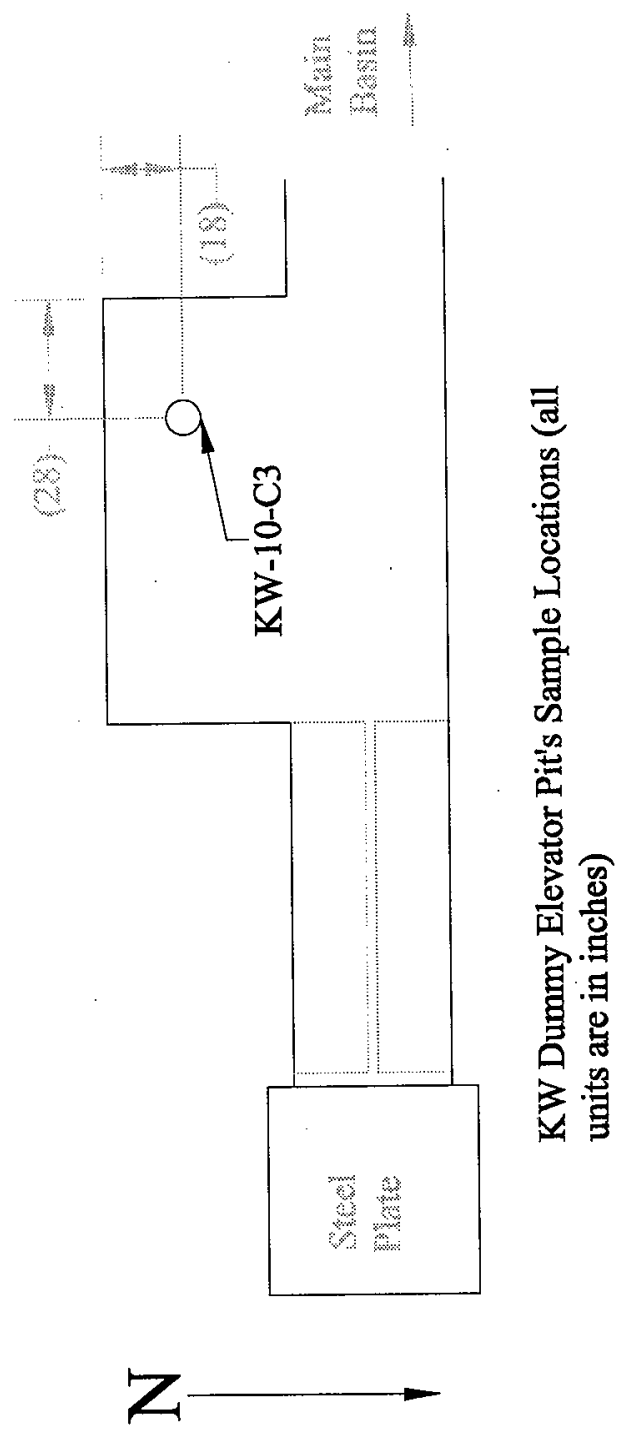


Figure B6. Fit of Sludge Depth Data in the Three Bays of $K$ East Main Basin in 1995. (Locations relate to Figure 4)

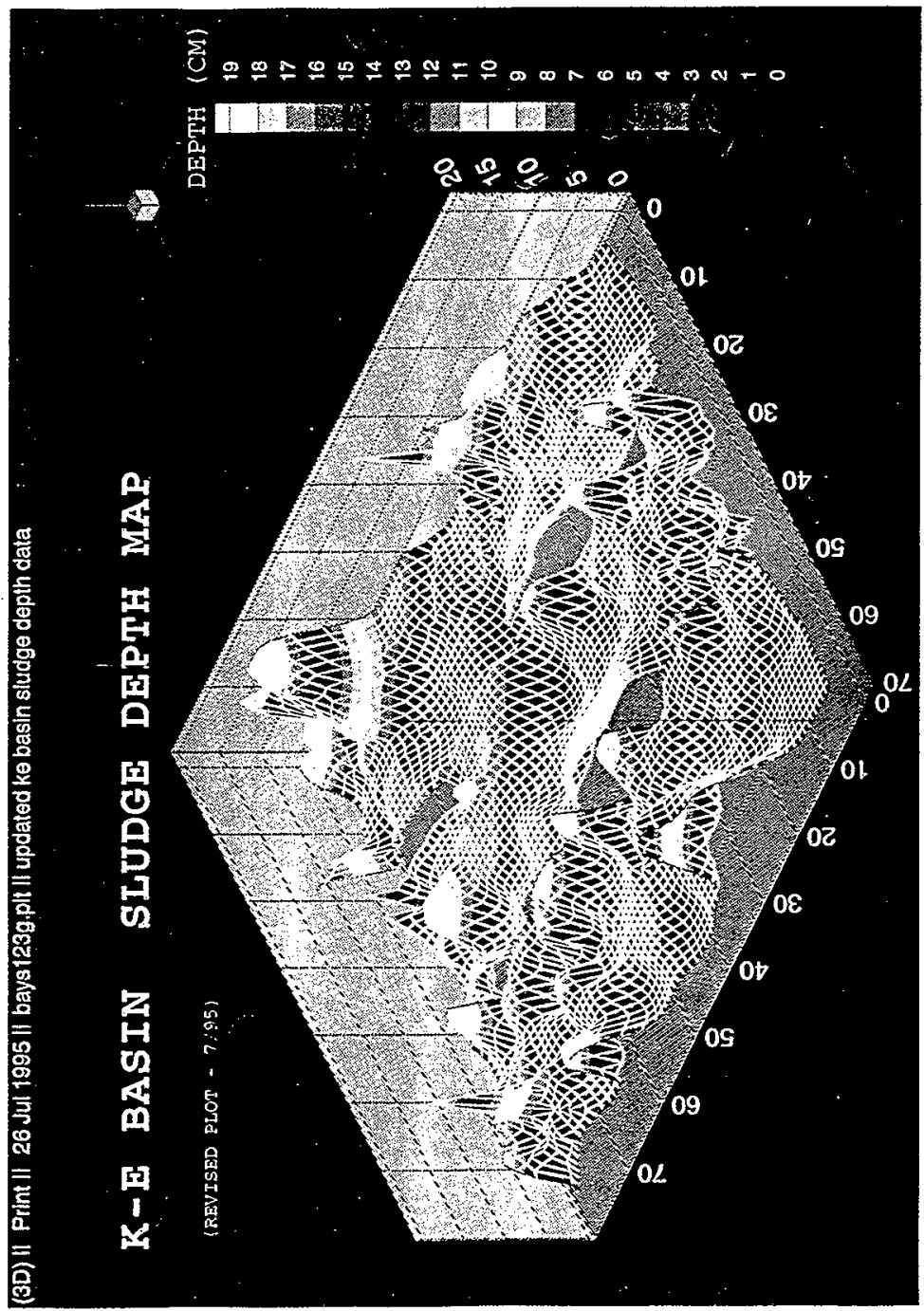


Figure B7. Sample Locations Used in 1995 Campaign in K East Basin.

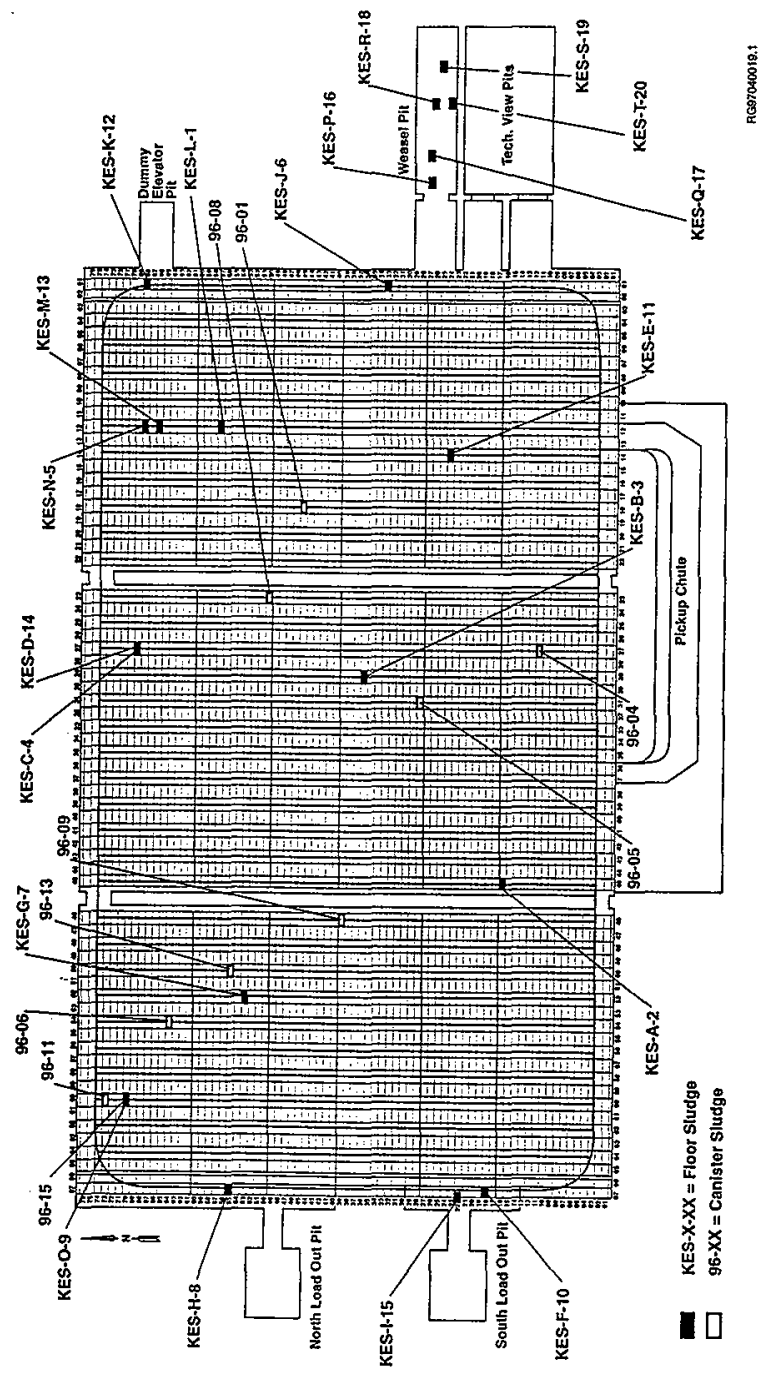



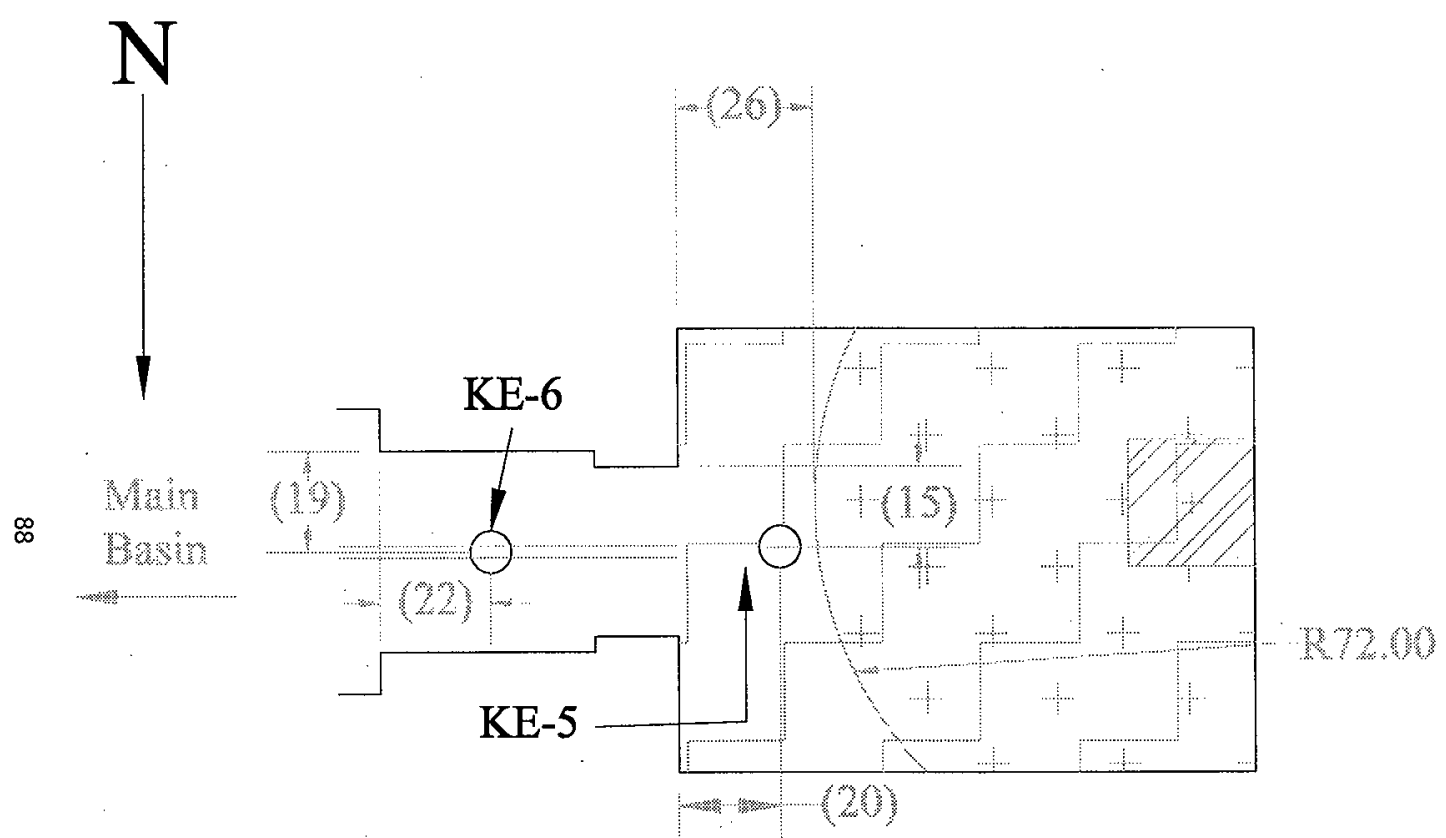

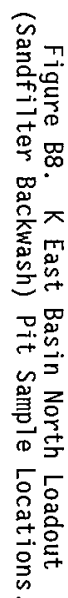

105-KE Basin North Loadout Pit's Exclusion Zone, Plywood Covering, and Sample Locations (all units are in inches) 
Figure B9. Surface Fit of S1udge Depth Data in K East Basin North Loadout (Sandfilter Backwash) Pit in 1995.

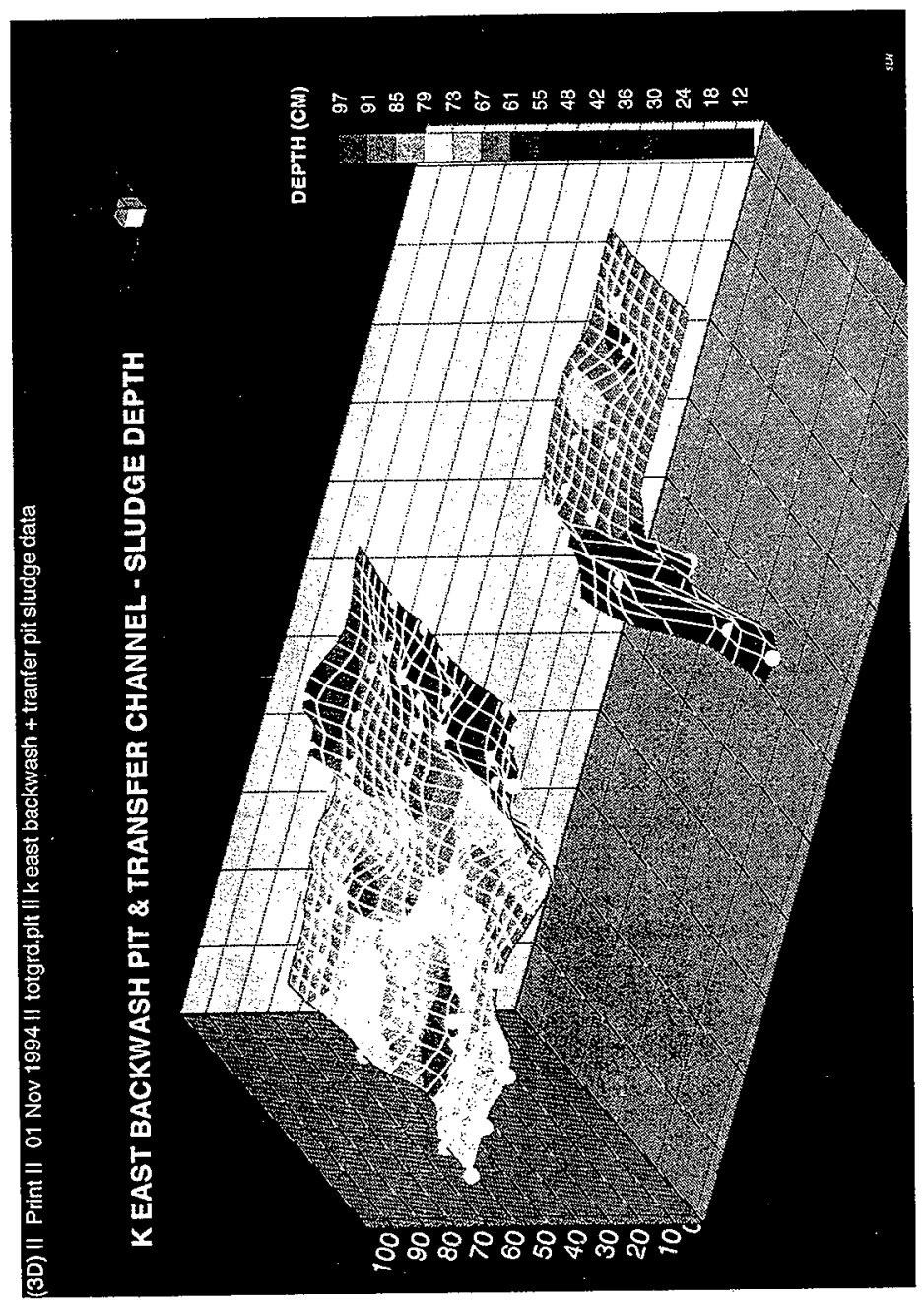


HNF-3556, Rev. 0

Figure B10. K East Basin Dummy Elevator Pit Sample Locations.

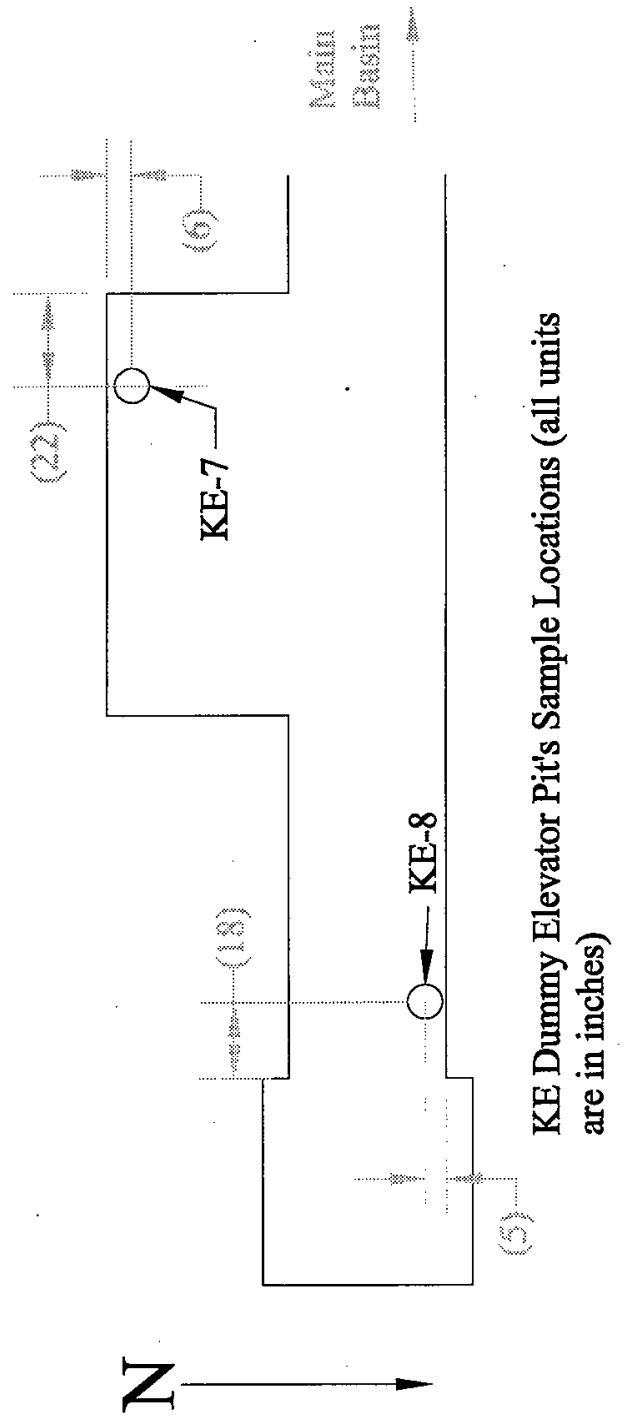


Figure B11. Sludge Depth Data for K East Basin Weasel Pit in 1995.

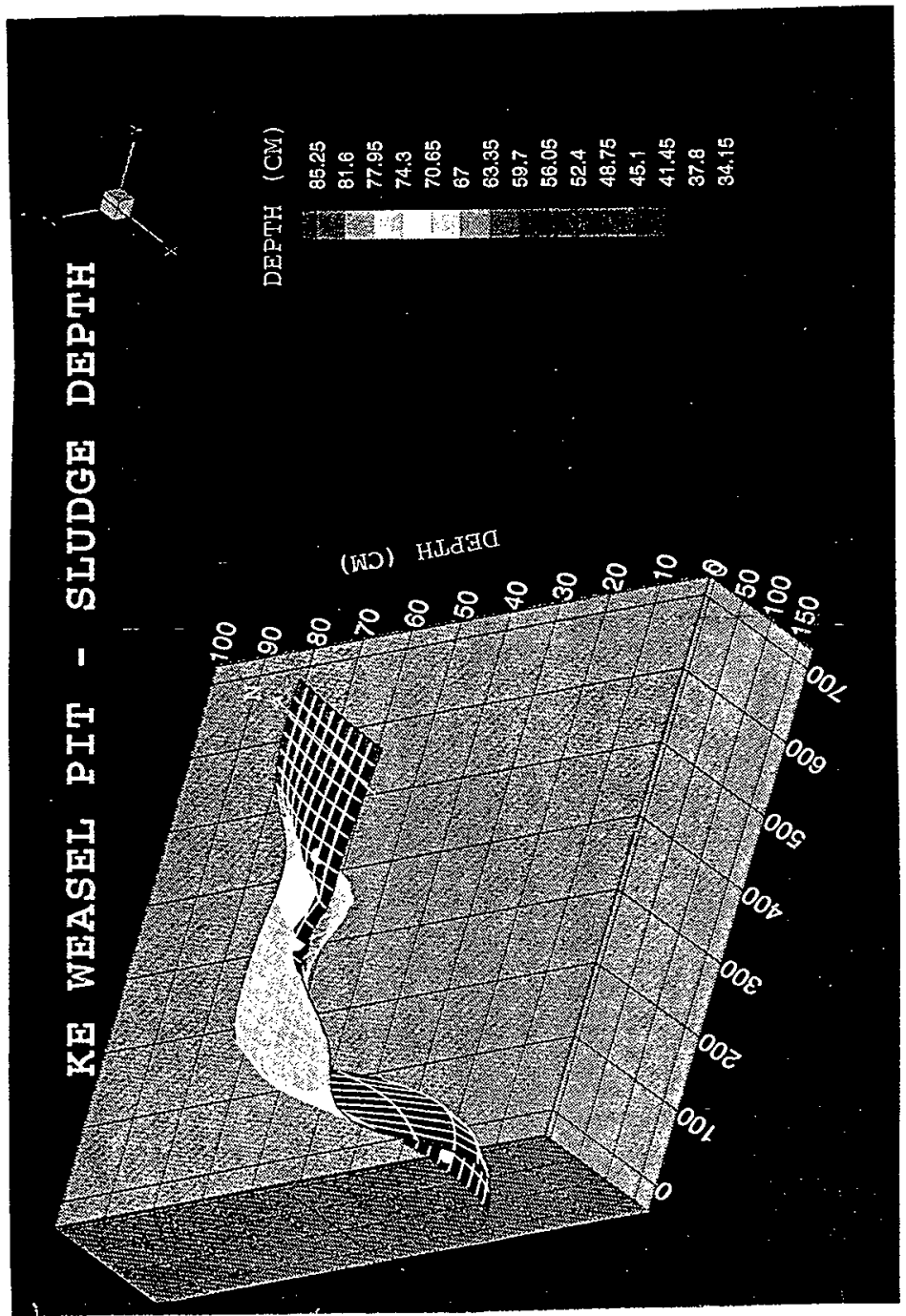


Figure B12. Sample Locations Used in the K East Basin Weasel Pit for the 1995 rampaign.

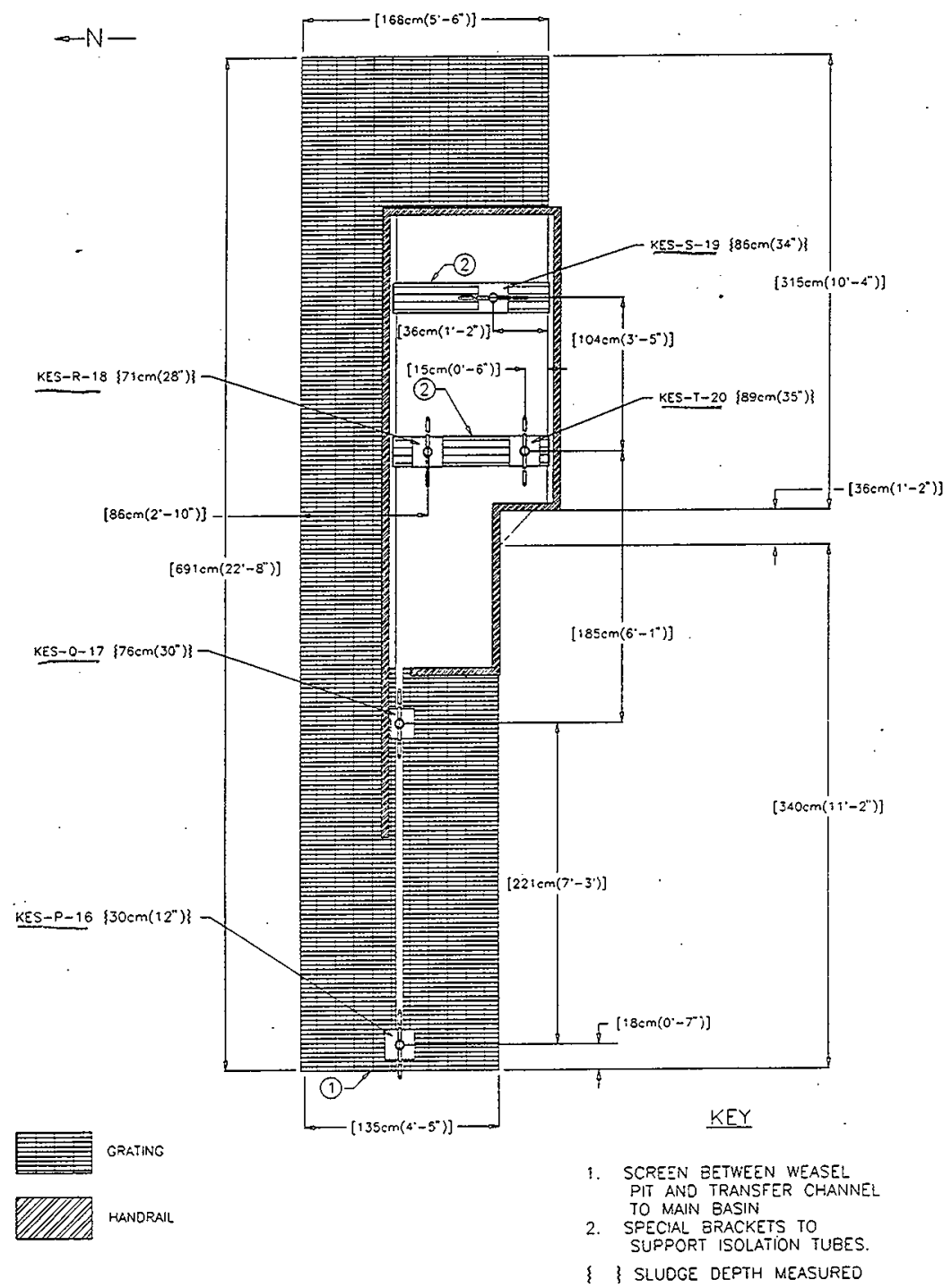


HNF-3556, Rev. 0

Figure B13. K East Basin Weasel Pit and Tech View Pit Sample Locations.

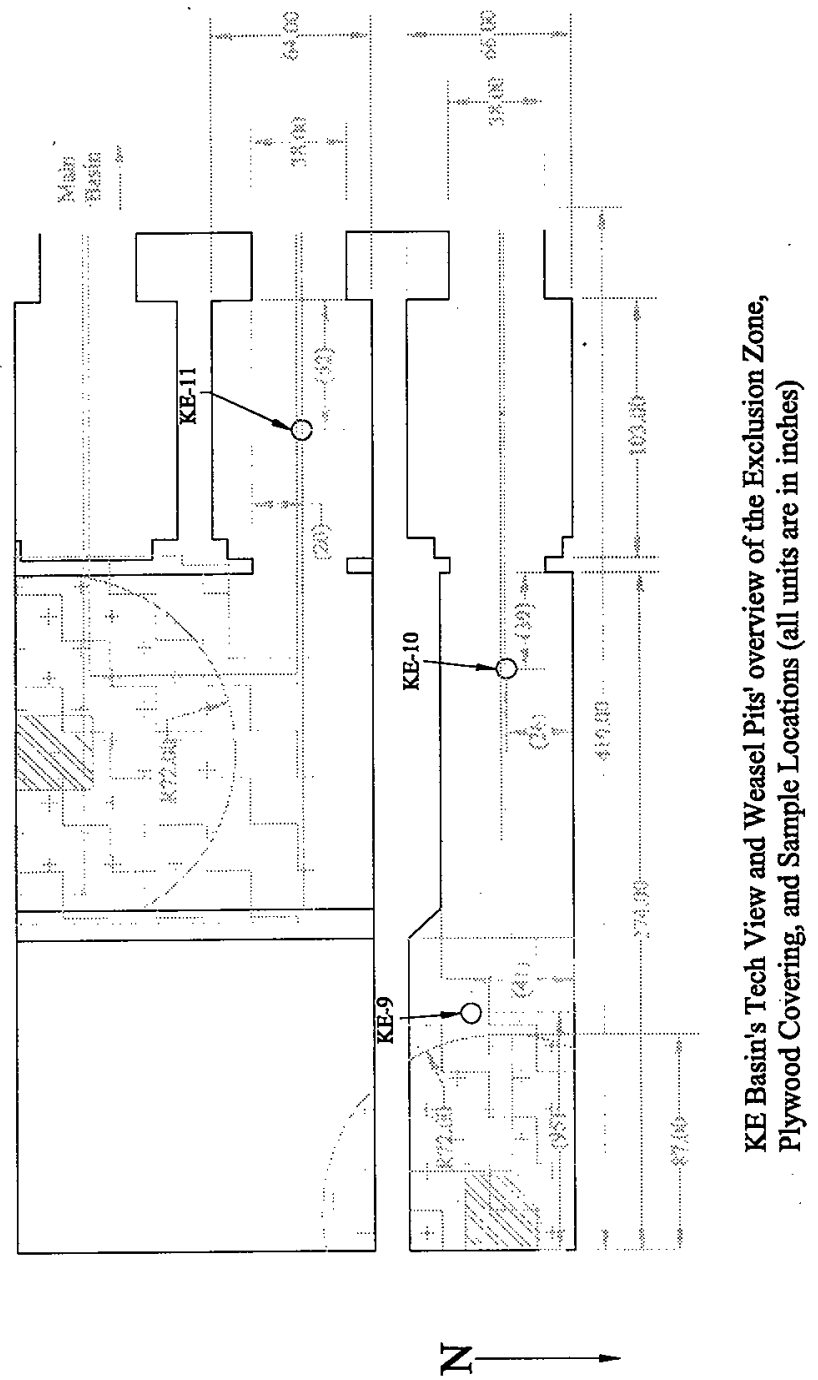




\section{DISTRIBUTION SHEET}

\begin{tabular}{|c|c|c|c|c|c|}
\hline \multirow{2}{*}{$\begin{array}{l}\text { To } \\
\text { Distribution }\end{array}$} & \multirow{2}{*}{\multicolumn{3}{|c|}{$\begin{array}{l}\text { From } \\
\text { SNF Characterization Project/ } \\
2 F 700\end{array}$}} & \multicolumn{2}{|l|}{ Page 1 of 2} \\
\hline & & & & \multicolumn{2}{|c|}{ Date November 1998} \\
\hline \multicolumn{4}{|l|}{ Project Title/Work Order } & \multicolumn{2}{|c|}{ EDT No. $\quad 620822$} \\
\hline \multicolumn{4}{|c|}{$\begin{array}{l}\text { Sampling and Analys is Plan for Sludge Located on the Floor and } \\
\text { in the Pits of the 105-K Basins/HNF-3556, Rev. } 0\end{array}$} & \multicolumn{2}{|l|}{ ECN No. } \\
\hline Name & MSIN & $\begin{array}{l}\text { Text } \\
\text { With All } \\
\text { Attach. }\end{array}$ & Text Only & $\begin{array}{l}\text { Attach./ } \\
\text { Appendix } \\
\text { Only }\end{array}$ & $\begin{array}{l}\text { EDT/ECN } \\
\text { Only }\end{array}$ \\
\hline
\end{tabular}

Eluor Daniel Hanford, Inc.

E. W. Gerber

R. L. McCormack

M. J. Wiemers

N. H. Williams

$\begin{array}{ll}\text { R3-11 } & X \\ \text { R3-11 } & X \\ \text { R3-11 } & X \\ \text { R3-11 } & X\end{array}$

B\&W Protec

Duke Engineering \& Services Hanford, Inc.

C. J. Alderman

R. B. Baker (2)

D. W. Bergmann

K. H. Bergsman

A. E. Bridges

R. W. Brown

L. D. Bruggeman

S. L. Hecht

D. P. Kimball

D. P. Maassen

P. J. MacFarlan

B. J. Makenas

K. R. Morris

J. Perez-Carter

A. L. Pitner

A. M. Segrest

D. W. Smith

J. A. Swenson

C. A. Thompson

D. J. Trimble

SNF Project File

$\begin{array}{ll}X 3-74 & X \\ H 0-40 & X \\ H 0-40 & X \\ X 3-85 & X \\ H 0-40 & X \\ X 3-65 & X \\ H 0-40 & X \\ H 0-40 & X \\ X 3-71 & X \\ H 0-40 & X \\ H 0-40 & X \\ H 0-40 & X \\ X 3-56 & X \\ H 0-40 & X \\ H 0-40 & X \\ \text { R3-11 } & X \\ \text { R3-11 } & X \\ \text { R3-11 } & X \\ X 3-72 & X \\ H 0-40 & X \\ \text { R3- 11 } & X\end{array}$

Duke Engineering \& Services Northwest, Inc.

$$
\text { M. J. Horhota }
$$

B1-13

X

\section{Informatics}

J. A. Serles

$\mathrm{HO}-40$ $x$
$x$
$x$
$x$$$
\text { . }
$$ 


\section{DISTRIBUTION SHEET}

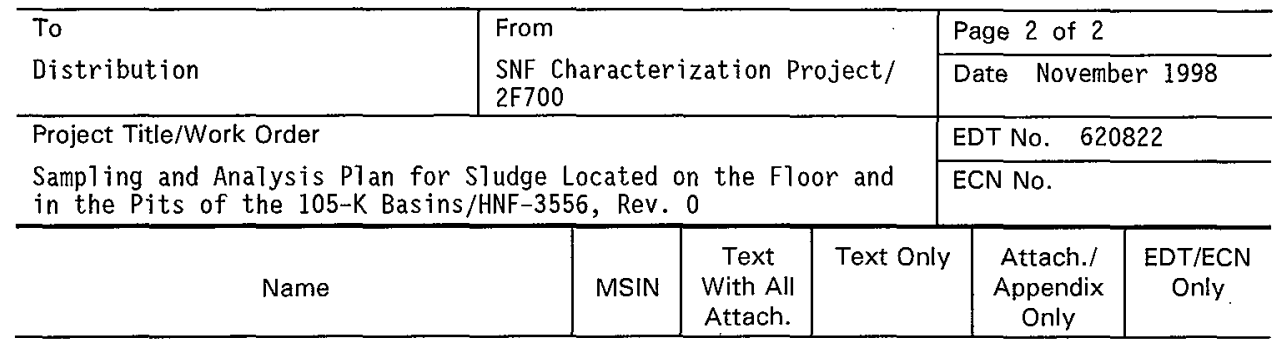

Lockheed Martin Services, Inc.

Central Files

DPC

Numatec Hanford Corporation

D. B. Bechtold

D. A. Dodd

T. A. Flament

K. L. Pearce

C. A. Petersen

W. W. Rutherford

$\begin{array}{ll}\text { A3-88 } & X \\ \text { A3-89 } & X\end{array}$

$X$
$X$

$\begin{array}{ll}\text { T6-07 } & X \\ \text { T6-50 } & X \\ H 7-20 & X \\ H 7-20 & X \\ \text { S4-45 } & X \\ H 7-20 & X\end{array}$

Pacific Northwest Nationa] Laboratory
P. R. Bredt
C. H. Delegard
G. R. Golcar
A. J. Schmidt
K. L. Silvers
J. M. Tingey

$\mathrm{P} 7-25$

P7-25

$\mathrm{K} 6-24$

$\mathrm{K} 2-12$

$\mathrm{K} 9-08$

P7-25

$X$
$X$
$X$
$X$
$X$
$X$

U.S. Department of Energy, Richland Operations Office
J. Shuen
$57-41$
$x$ 